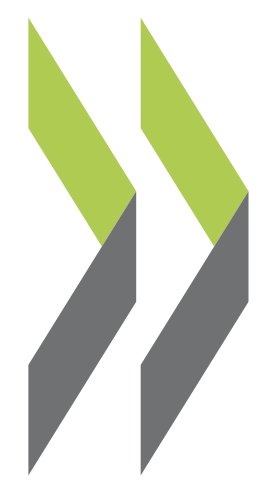

OECD Economics Department Working Papers No. 1385

\section{A revised approach}

to productivity convergence in long-term scenarios
Yvan Guillemette, Alexandre Kopoin, David Turner, Andrea De Mauro 


\section{Unclassified}

ECO/WKP(2017)17

Organisation de Coopération et de Développement Économiques

Organisation for Economic Co-operation and Development

16-May-2017

ECONOMICS DEPARTMENT

English - Or. English

\section{A REVISED APPROACH TO PRODUCTIVITY CONVERGENCE IN LONG-TERM SCENARIOS}

ECONOMICS DEPARTMENT WORKING PAPERS No. 1385

By Yvan Guillemette, Alexandre Kopoin, David Turner and Andrea De Mauro

OECD Working Papers should not be reported as representing the official views of the OECD or its member countries. The opinions expressed and arguments employed are those of the author $(s)$.

Authorised for publication by Christian Kastrop, Director, Policy Studies Branch, Economics Department.

All Economics Department Working Papers are available at www.oecd.org/eco/workingpapers

JT03414227

Complete document available on OLIS in its original format

This document, as well as any data and map included herein, are without prejudice to the status of or sovereignty over any territory, to the delimitation of international frontiers and boundaries and to the name of any territory, city or area. 
OECD Working Papers should not be reported as representing the official views of the OECD or of its member countries. The opinions expressed and arguments employed are those of the author(s).

Working Papers describe preliminary results or research in progress by the author(s) and are published to stimulate discussion on a broad range of issues on which the OECD works.

Comments on Working Papers are welcomed, and may be sent to OECD Economics Department, 2 rue André Pascal, 75775 Paris, Cedex 16, France, or by e-mail to eco.contact@oecd.org.

All Economics Department Working Papers are available at www.oecd.org/eco/workingpapers.

The statistical data for Israel are supplied by and under the responsibility of the relevant Israeli authorities. The use of such data by the OECD is without prejudice to the status of the Golan Heights, East Jerusalem and Israeli settlements in the West Bank under the terms of international law.

This document and any map included herein are without prejudice to the status of or sovereignty over any territory, to the delimitation of international frontiers and boundaries and to the name of any territory, city or area.

\section{(C) OECD (2017)}

You can copy, download or print OECD content for your own use, and you can include excerpts from OECD publications, databases and multimedia products in your own documents, presentations, blogs, websites and teaching materials, provided that suitable acknowledgment of OECD as source and copyright owner is given. All requests for commercial use and translation rights should be submitted to rights@oecd.org 


\section{ABSTRACT/RÉSUMÉ \\ A revised approach to productivity convergence in long-term scenarios}

The paper describes revisions to the trend labour efficiency component of the production function underpinning long-term economic scenarios. The main goal of the revision is to add more policy and institutional determinants in the equation to enrich the scenarios that can be constructed. In the proposed equation, equilibrium trend labour efficiency depends on a broad measure of the quality of institutions and governance (the World's Bank rule of law indicator), human capital (based on average years of schooling attainment), product market regulation (PMR), openness to trade adjusted for country size, the stability of the macroeconomic framework (based on inflation and its variance), income inequality (based on GINI coefficients) as well as domestic and global research and development (via accumulated stocks of R\&D). Apart from the innovation effects, the sizes of the other effects are jointly estimated in a conditional convergence framework with a sample of about 120 countries, without the use of country fixed effects. Rule of law and openness are also estimated to influence the speed of convergence toward the long-term equilibrium.

JEL classification codes: $\mathrm{O} 47, \mathrm{O} 43, \mathrm{C} 53$

Keywords: Productivity, projections, trend labour efficiency, TFP, conditional convergence, development, rule of law, openness, long-term model, long-term scenarios

************

\section{Une approche révisée pour la convergence de la productivité dans les scénarios à long terme}

L'étude décrit les révisions de la composante d'efficience du travail tendancielle de la fonction de production qui sous-tend les scénarios économiques à long terme. Le but principal de la révision est d'ajouter à l'équation des canaux de politique publique et institutionnels pour enrichir les scénarios qu'il est possible de construire. Dans l'équation proposée, l'efficience du travail tendancielle dépend d'une mesure englobante de la qualité des institutions et de la gouvernance (l'indicateur règle de droit de la Banque Mondiale), du capital humain (basé sur le nombre moyen d'années d'étude), de la règlementation du marché des produits (PMR), de l'ouverture au commerce mondial ajusté pour la taille du pays, de la stabilité de l'environnement macroéconomique (basée sur l'inflation et sa variance), des inégalités de revenus (basés sur le coefficient de GINI) et de la recherche et développement au niveau domestique et global (via les stocks accumulés de $\mathrm{R} \& \mathrm{D}$ ). Mis à part les effets d'innovation, les autres sont conjointement estimés dans un modèle de convergence conditionnelle avec un échantillon d'environ 120 pays, sans utiliser d'effets fixes par pays. La règle de droit et l'ouverture au commerce mondial affectent aussi la vitesse de convergence vers l'équilibre long terme.

Classification JEL: O47, O43, C53

Mots clefs : Productivité, projections, efficience du travail tendancielle, TFP, convergence conditionnelle, règle de droit, ouverture, modèle long-terme, scénarios à long terme 


\section{TABLE OF CONTENTS}

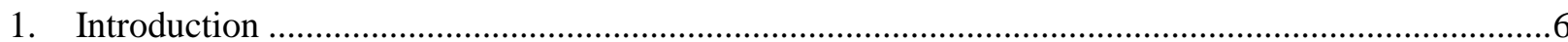

2. Historical estimates of labour efficiency and the framework for projections....................................

2.1 Historical labour efficiency estimates and short-run projections ..........................................

2.2 The conditional convergence framework and the old method for labour efficiency projections 8

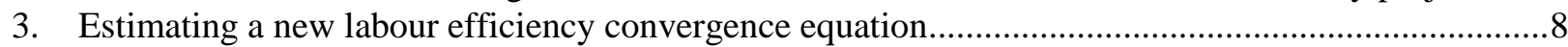

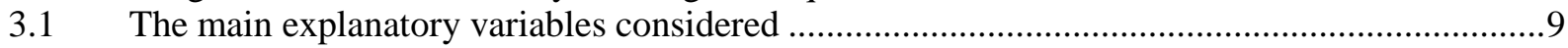

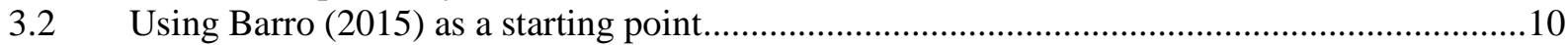

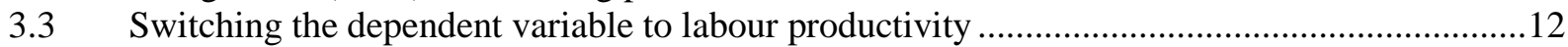

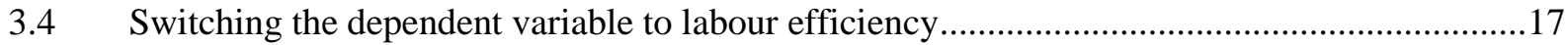

3.5 Other variables tested and robustness of the preferred equation ..............................................21

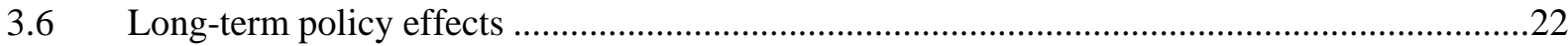

3.7 Comparison and consistency with other recent OECD work on productivity convergence......24

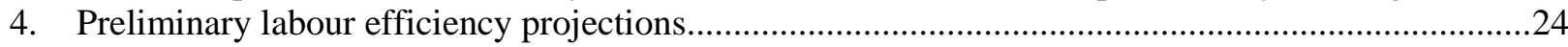

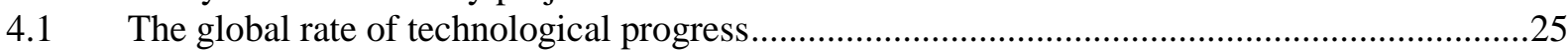

4.2 Initial gaps to equilibrium labour efficiency and growth residuals .......................................26

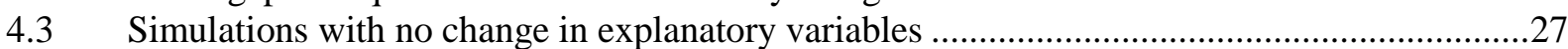

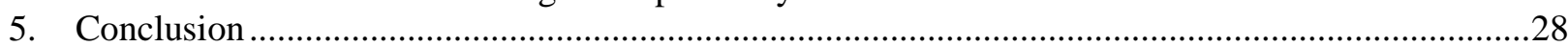

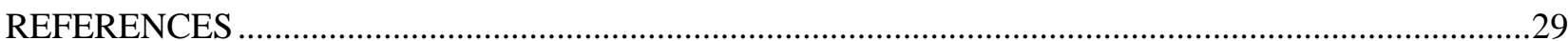

APPENDIX 1. THE PREVIOUS PRODUCTIVITY CONVERGENCE EQUATIONS …........................33

APPENDIX 2. DESCRIPTIVE STATISTICS FOR THE EXPLANATORY VARIABLES ......................34

APPENDIX 3. CONSTRUCTING A POPULATION-ADJUSTED OPENNESS MEASURE...................42

APPENDIX 4. CONSTRUCTING PRODUCT MARKET REGULATION MEASURES .........................44

APPENDIX 5. CONSTRUCTING A HUMAN CAPITAL MEASURE........................................................47

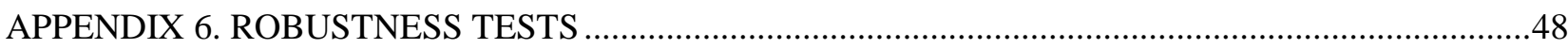

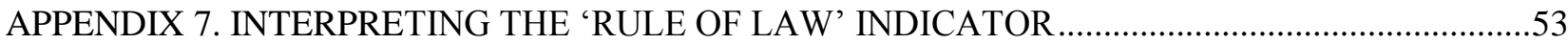

\section{Tables}

Table 1. Replicating Barro's regressions for GDP per capita ...............................................................11

Table 2. Regressions for conditional convergence in labour productivity..............................................13

Table 3. Regressions for conditional convergence in labour efficiency ..................................................18

\section{Figures}

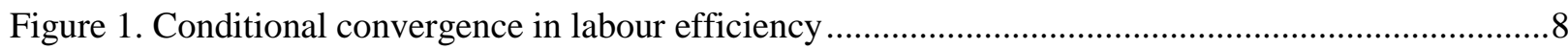

Figure 2. GDP per capita, labour productivity and labour efficiency …..................................................

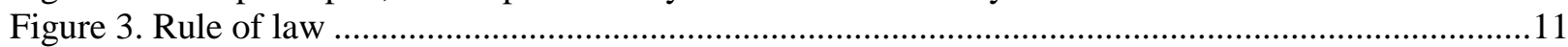

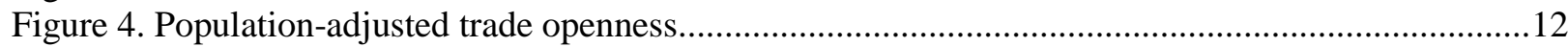


Figure 5. Measure of human capital based on educational attainment ................................................14

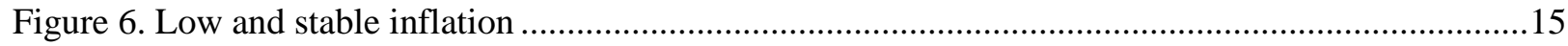

Figure 7. Product Market Regulation.......................................................................................... 16

Figure 8. Measure of innovation based on R\&D expenditures ..............................................................19

Figure 9. Measure of innovation based on patent applications .............................................................19

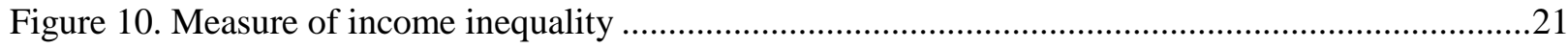

Figure 11. Relative influence of productivity determinants...................................................................23

Figure 12. Differences from baseline labour efficiency following PMR reform.....................................23

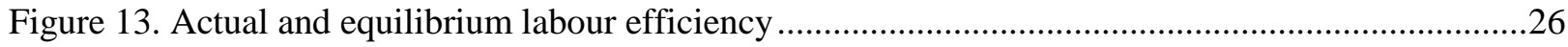

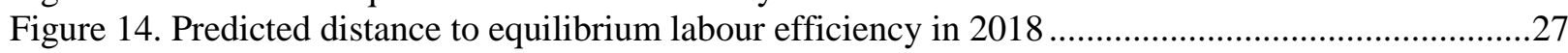

Figure 15. Trend labour efficiency growth under no-policy-change assumptions .................................28 


\title{
A REVISED APPROACH TO PRODUCTIVITY CONVERGENCE IN LONG-TERM SCENARIOS
}

\author{
By Yvan Guillemette, Alexandre Kopoin, David Turner and Andrea de Mauro ${ }^{1}$
}

\section{Introduction}

1. Since the early 1990s, the OECD has sought to extend the short-term projection horizon of the OECD Economic Outlook (EO) to peer into medium and long-term trends and describe different possible scenarios. The long-term projections have proven to be a popular product, ostensibly because they can address a range of issues - fiscal sustainability, the consequences of demographic change, the effects of structural reforms, the catch-up of emerging economies, etc. - which play out over a long horizon. But producing coherent long-term scenarios for a wide range of countries is fraught with many challenges, and the current methodology can and should be improved in many ways.

2. In standard growth theory, in the long run, all of the gains in living standards are driven by productivity growth. The equation that determines the evolution of productivity is thus a central plank of the long-term model, one on which much of the rest of the model is anchored, and the first place to look for possible improvements. Other papers will describe revisions to other parts of the model that determine the other components of potential output, as well as saving, investment, current account balances, fiscal accounts, interest rates, exchange rates and international linkages, but any revisions to these other parts are likely to be more incremental than transformative.

3. It should be noted at the outset that this paper's primary aim is not to contribute to the alreadylarge literature on the determinants of growth. The main goal is instead to select a parsimonious set of variables to underpin the evolution of productivity in a simulation model and arrive at reasonable magnitudes for their influence. One possibility would have been to pluck coefficient estimates from existing empirical studies, but this would have run the risk of combining effects estimated in different and possibly inconsistent frameworks, and of double counting given the high correlation between typical productivity determinants. Instead, the empirical work starts from a widely recognised framework in the literature, namely Robert Barro's work on income convergence in GDP per capita, and gradually adapts the estimation to move from GDP per capita to labour productivity and finally to labour efficiency, all the while focusing on the variables deemed most interesting in the context of long-term scenarios. In this way, an attempt is made to estimate many of the relevant effects together simultaneously in a coherent framework. Still, data limitations and econometric challenges mean that judgement is sometimes required and some effects nevertheless need to be imposed from external studies.

4. The paper is structured as follows: section 2 briefly describes the computation of historical estimates of labour efficiency, the productivity concept used in the long-term model (more on this below), as these serve as starting points for the long-run projections. Section 3 presents the estimation work carried out to inform the new productivity equation, and section 4 presents a few preliminary simulations based on the new equation. Section 5 concludes.

1. The authors are members of the OECD Economics Department's Macroeconomic Analysis Division. They would like to thank Alain de Serres, Balázs Égert, Rauf Gonenc, Catherine Mann, Jean-Luc Schneider and Jan Strasky for comments and discussions; and Veronica Humi for editorial support (all from the OECD Economics Department). The paper also benefited from discussions at Economics Department seminars as well as meetings of Working Party No. 1 of the OECD's Economic Policy Committee. 


\section{Historical estimates of labour efficiency and the framework for projections}

5. This section briefly summarises how trend labour efficiency is estimated for the historical period and then projected over the EO short-term horizon, which as of writing extends to 2018. This short-term projection serves as the starting point for the long-run simulations.

\subsection{Historical labour efficiency estimates and short-run projections}

6. Historical trend labour efficiency estimates are produced as part of estimating potential output for the twice-yearly EO. Potential output is based on an aggregate production function approach using trend input components, namely a constant-returns-to-scale Cobb-Douglas specification with Harrod-neutral labour-augmenting technical progress. Using real GDP (GDPV); total employment (ET, the national account measure where available otherwise a labour force survey based measure); estimates of wholeeconomy productive capital stock (KPTV); and assuming that the share of national income accruing to labour $(\alpha)$ is 0.67 in all countries ${ }^{2}$, the following expression is formed in which only labour efficiency $(E F F L A B)$ is unknown:

$$
G D P V_{t}=\left(E F F L A B_{t} \cdot E T_{t}\right)^{\alpha} K T P V_{t}^{1-\alpha}
$$

Labour efficiency is calculated as a residual using the above production function for the decomposition. ${ }^{3}$ To alleviate any end-point bias before filtering, the raw series is cyclically adjusted using business cycle measures external to the production function methodology. ${ }^{4}$ Trend labour efficiency is then computed by filtering the cyclically-adjusted series with a Hodrick-Prescott (HP) filter. It is extended forward over the short-run EO horizon using an average growth rate of the two to three previous years on the basis that a trend growth measure should by definition be roughly stable over a short horizon.

7. At the time when the previous long-term projection model was developed, the production function underlying potential output had human capital entering explicitly as a factor of production. The labour efficiency measure obtained by decomposition was thus purged of the human capital influence on the basis of a specific assumption on how this factor contributed to production. Human capital stock estimates are fraught with uncertainties, however, and different estimates can yield very different historical labour efficiency profiles for a given country (OECD, 2015; Égert, 2015). ${ }^{5}$ Moreover, as this labour efficiency measure was the basis for the estimation of policy effects and convergence speed, any uncertainty or bias in in it was reflected in the estimation results, which also served as a basis for projections. Some time ago, the EO moved away from using a labour efficiency measure that attempts to strip away the influence of human capital and the revised long-term model adopts this same convention. To capture quality-of-labour effects, a measure of human capital will instead be included among the regressors that determine the long-run level of labour efficiency in the estimated convergence equation.

2. This parameter roughly corresponds to the wage share in advanced economies and has proven to be quite stable in time. This is less true of emerging economies, however, and future work could consider the consequences of allowing the wage share to vary across country, through time, or both.

3. In this framework, labour efficiency $(E F F L A B)$ and total factor productivity $(T F P)$ - that part of output not explained by factor inputs - are closely related but distinct concepts: TFP $=E F F L A B^{\alpha}$.

4. See Turner et al. (2016) for details on this cyclical adjustment procedure and for more on potential output estimation in general.

5. Measures of labour efficiency, or similarly total factor productivity (TFP), can vary according to various assumptions relating to the measurement of the capital stock, the use of alternative deflators and whether human capital is included or excluded. 


\subsection{The conditional convergence framework and the old method for labour efficiency projections}

8. While there is no single theory of economic growth, there is wide support for an analytical framework in which each country converges to its own steady-state trajectory of GDP per capita, determined by the interface between global technological progress and country-specific structural conditions and policies (Barro, 1991; Barro and Sala-i-Martin, 1992; Mankiw, Romer and Weil, 1992). In this so-called conditional convergence framework, all countries eventually grow at the same long-run rate, determined by the worldwide rate of technological progress, but cross-country GDP per capita gaps remain, mainly reflecting differences in technology levels, capital intensity, human capital and demographics. These in turn partly depend on differences in structural conditions and policies. In this framework, two forces can act to reduce cross-country GDP per capita gaps in the long run. First, countries initially below their steady-state level of GDP per capita 'catch up' to this level, principally as a result of accumulating different kinds of capital (human and physical) and efficiency improvements driven by technology adoption and innovation. Second, cross-country differences in steady-state GDP per capita are evened out as some structural conditions converge (e.g. due to globalisation) and best policy practices disseminate, affecting in turn factor accumulation and efficiency improvements.

Figure 1. Conditional convergence in labour efficiency

A. In levels

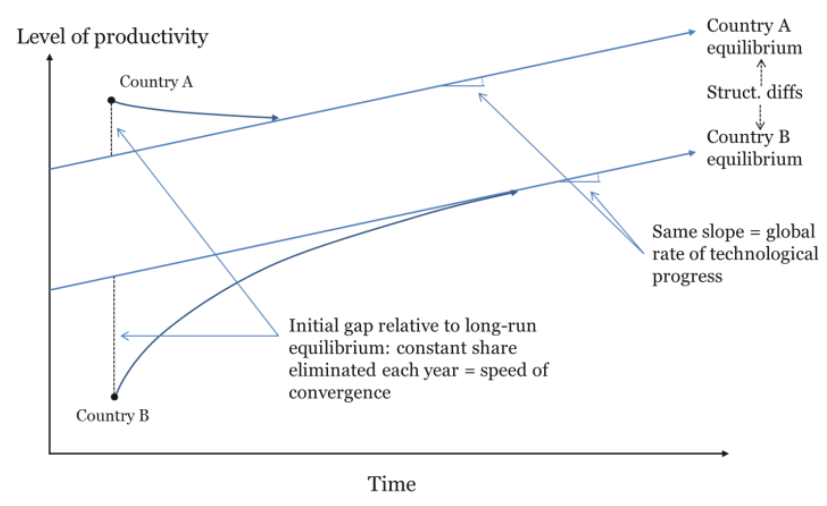

B. In growth rates

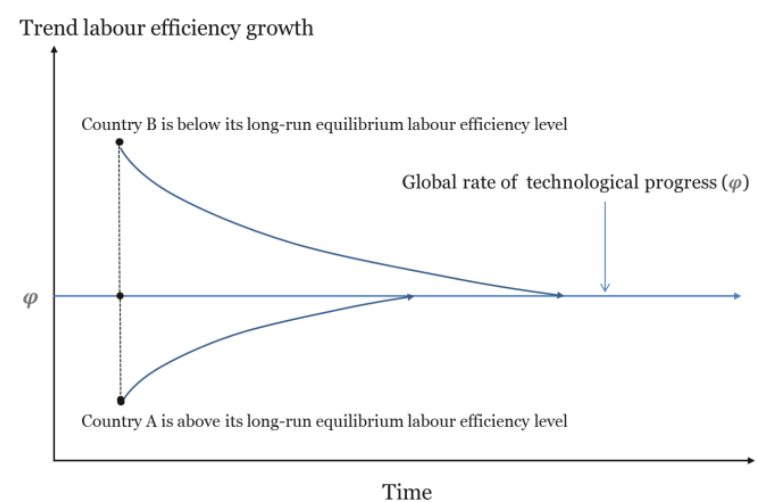

9. In the long-term model, the conditional convergence framework is applied directly to the labour efficiency component of potential output, and the future evolution of potential employment and the capital stock are determined separately. Conditional convergence in labour efficiency is represented graphically below for two hypothetical countries (Figure 1). In this example, country A's structural conditions are superior to country B's and, all else equal, so are living standards. However, labour efficiency growth is expected to be lower in country A going forward because it is above its long-run equilibrium (as represented by the vertical distance between its initial position and the diagonal line that represents the long-run equilibrium), while the reverse is true of country B. Also, both countries could boost labour efficiency by improving their structural conditions, which graphically would shift the 'equilibrium' diagonal lines upward. After such a shift, labour efficiency growth rates would rise relative to a no-change scenario, but only temporarily until the new equilibria are reached.

\section{Estimating a new labour efficiency convergence equation}

10. This section describes the various estimations done and the decisions made along the way to arrive at a final specification that will be used as the basis for the labour efficiency projection equation in the long-term model. For comparison, a summary description of the previous productivity convergence equations is in Appendix 1. The main goal of the revision is to add more institutional and policy variables 
to explain the convergence process. A GDP-per-capita equation is estimated first, before switching the dependent variable to labour productivity (GDP per worker) and finally to labour efficiency. To maximise country and time coverage, the data for the various dependent variables are sources from the Penn World Tables (PWT), version 8.1 (Figure 2).

Figure 2. GDP per capita, labour productivity and labour efficiency

Average log values for the last period used in estimation (2006 to 2010)

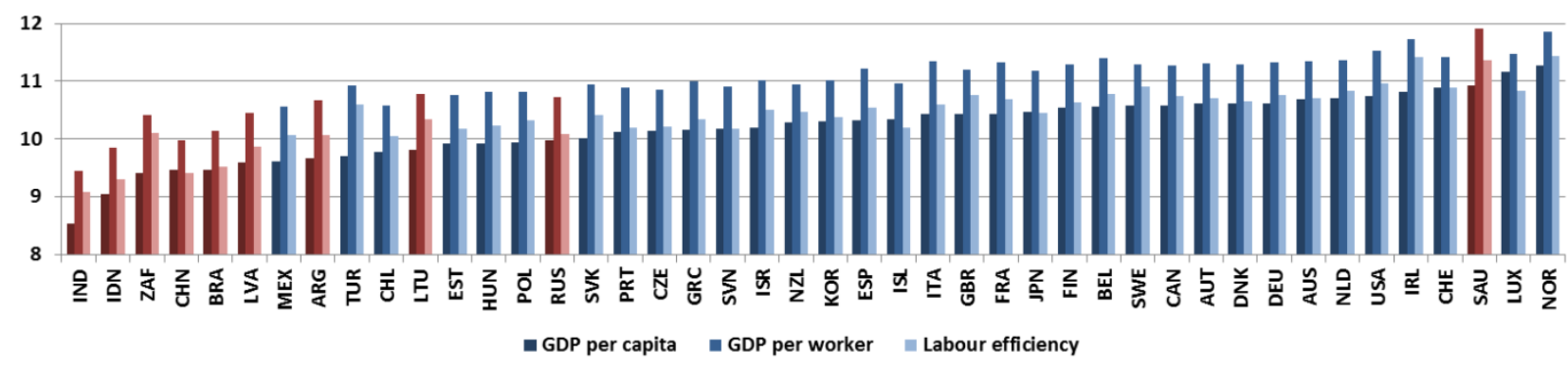

Source: Penn World Tables v8.1. Labour efficiency is obtained by decomposition using a Cobb-Douglas production function with a fixed wage share of two thirds, following EO methodology. See Figure A2.1 for all countries in the final regression sample.

\subsection{The main explanatory variables considered}

11. The main determinants of the economic convergence process considered in the estimations below are inspired from the existing empirical growth literature, and include the following:

1. The initial level of income. This is the most important and robust factor, so conditional convergence is the most robust empirical fact in the data.

2. Governance and institutions. The economic history of the past two centuries, and much recent work on the economics of institutions, has established a strong theoretical and empirical case that the quality of governance and institutions matters a great deal for growth (see Hall and Jones, 1999; Acemoglu et al., 2001; Acemoglu et al., 2005). Free markets, protection for property rights and respect for the rule of law are fundamental conditions for growth. For instance, a legal environment that allows entrepreneurs to protect their intellectual and physical property and appropriate a significant fraction of the revenues generated by their innovations should encourage innovative investments and productivity growth.

3. Macro environment. The quality of macroeconomic management is thought to be important in setting the conditions for investment and growth. This can include fiscal and various other policy areas, but the growth literature has found that low and stable inflation is particularly important.

4. Human capital. Despite the important role often attributed to human capital in growth theory, empirical evidence has long been mixed (for an overview see Hanushek and Woessmann, 2010). Cross-country growth studies usually measure human capital as average schooling attainment in the working-age population, and often find a weak impact on growth. Some authors have had stronger results when using quality-adjusted measures, for instance using average scores on standardised tests to measure quality (e.g. Islam et al., 2014; Barro and Lee, 2015).

5. Regulation. Numerous studies suggest that economies with relatively light product market regulation that fosters competition tend to grow faster (Arnold et al., 2008; Bouis et al., 2011; Bourlès et. al, 2013; Cette et al., 2013 and 2014; Conway et al., 2006; Nicoletti and Scarpetta, 
2005). Unfortunately, reliable and comparable indicators of the quality of regulation are hard to come by for a wide spectre of countries. In the estimations below, the aggregate OECD Product Market Regulation (PMR) indicator is used when available and a proxy measure is constructed for countries and years where the OECD PMR is not available (see Appendix 4). Labour market regulation is not considered as little data on such regulation are available for non-OECD countries and recent OECD work has found that labour market policies do not have a robust empirical relation to total factor productivity (Égert and Gal, 2017).

6. Openness. Trade is a well-documented channel for technology transfers and spillovers between countries, so more open economies are expected to catch up more quickly to the technology frontier (Saia et al., 2015). More open economies also tend to grow faster as stronger external competition and a higher threat of entry tends to encourage innovation by incumbent firms. By this logic, openness should benefit small countries to a greater extent than large ones as the latter already have internal markets big enough to breed competition and achieve economies of scale. For this reason, the openness variable used in the estimations below is a population-adjusted measure.

\subsection{Using Barro (2015) as a starting point}

12. The ultimate objective is to estimate an equation for the long-run conditional convergence of labour efficiency levels across countries. However, most of the existing empirical work uses GDP per capita as the dependent variable instead of some measure of productivity. So, to provide a recognisable point of reference, a panel equation for GDP per capita is estimated first (Table 1).

13. The specification chosen comes from a framework developed by Barro (1991, 1997, 2003, 2015), a leading scholar in growth empirics. A particular focus is the specification in Table 1 reported in Barro (2015) in which convergence of real GDP per capita in a large panel of countries is explained by a linear regression model with the annual average growth rate of GDP per capita as the dependent variable and measures of institutions relating to governance, proxied by indicators for the rule of law (Figure 3 ) and democracy, as key explanatory variables, together with life expectancy, the fertility rate, average years of schooling, the ratios of investment and government consumption to GDP, inflation and trade openness. Descriptive statistics for all variables appearing in the estimations are in Table A2.1 in Appendix 2. For reasons of consistency with other OECD work (e.g. Égert, 2016), and to provide a better indicator as explained above, openness is a population-adjusted measure calculated using OECD methodology (Figure 4 and Appendix 3). Because a lagged dependent variable is included to capture the initial income level, the estimated panel equation can be expressed in error-correction form as follows:

$$
\Delta y_{i, t}=\gamma_{t}+\rho\left(y_{i, t-1}-\alpha-\sum_{k=1}^{K} \boldsymbol{\beta}_{k} \boldsymbol{X}_{i, t-1, k}\right)+\varepsilon_{i, t}
$$

where $\Delta$ is the first-difference operator, $y_{i, t}$ is the log of GDP per capita for country $i$ in year $t, \gamma_{t}$ are time fixed effects, $\rho$ is the convergence speed (which should take a negative value), $\alpha$ is a constant, $\boldsymbol{X}$ is a vector containing $K$ explanatory variables, $\boldsymbol{\beta}$ is its vector of coefficients, and $\varepsilon$ is the error term. To minimize the influence of economic cycles, and following Barro (2015), the equation is estimated using non-overlapping 5-year period averages. The actual equation estimated is a transformed version of the ECM specification which is linear in the coefficients. It is estimated using Ordinary Least Squares (OLS). ${ }^{6}$

6. Coefficient estimates from this specification are possibly biased by the endogeneity of essentially all of the right-hand side variables (structural indicators). However, it has typically proven difficult in growth studies to find valid instruments for these variables. Also, when trying a two-stage regression setup with longer or additional lags of the regressors as instruments, Barro (2015) finds that coefficient estimates change little, in particular the convergence speed. On this basis, this paper uses OLS for all equations. 
The errors are clustered at the country level to allow for correlation among observations within the same country over time. After estimation, the long-term effects of the explanatory variables $\left(\widehat{\boldsymbol{\beta}}_{k}\right)$ can be recovered by dividing their estimated coefficients by the negative of the estimated speed of convergence $\left(\widehat{\boldsymbol{b}}_{k} /-\hat{\rho}\right)$.

Table 1. Replicating Barro's regressions for conditional convergence in GDP per capita

Dependent variable: Annual growth rate of GDP per capita in USD at fixed PPPs averaged over five-year periods

\begin{tabular}{|c|c|c|c|c|}
\hline & (1) & $(2)$ & (3) & (4) \\
\hline Country fixed effects & No & Yes & No & Yes \\
\hline log(Lagged GDP per capita) & $\begin{array}{l}-0.0005 \\
(0.0012)\end{array}$ & $\begin{array}{c}-0.0401^{* * *} \\
(0.0061)\end{array}$ & $\begin{array}{c}-0.0176^{* * *} \\
(0.0021)\end{array}$ & $\begin{array}{c}-0.0661^{* * *} \\
(0.0075)\end{array}$ \\
\hline 1 / (Life expectancy at birth) & $(0.00-2)$ & $(0.0001)$ & $\begin{array}{c}-3.2080^{* * *} \\
(0.5541)\end{array}$ & $\begin{array}{l}-1.4180 \\
(1.0414)\end{array}$ \\
\hline $\log$ (Fertility rate) & - & - & $\begin{array}{c}-0.0138^{* * *} \\
(0.0049)\end{array}$ & $\begin{array}{c}-0.0546^{* * *} \\
(0.0109)\end{array}$ \\
\hline Rule of law & - & - & $\begin{array}{c}0.0083^{* * *} \\
(0.0025)\end{array}$ & $\begin{array}{l}0.0167^{* *} \\
(0.0083)\end{array}$ \\
\hline Investment ratio & - & - & $\begin{array}{l}0.0929 * * * \\
(0.0216)\end{array}$ & $\begin{array}{l}0.0920^{* *} \\
(0.0359)\end{array}$ \\
\hline Female total school years & - & - & $\begin{array}{c}0.0025 \\
(0.0017)\end{array}$ & $\begin{array}{c}0.0029 \\
(0.0054)\end{array}$ \\
\hline Male total school years & - & - & $\begin{array}{c}-0.0041^{* *} \\
(0.0020)\end{array}$ & $\begin{array}{c}-0.0068 \\
(0.0052)\end{array}$ \\
\hline Government consumption ratio & - & - & $\begin{array}{l}-0.0223 \\
(0.0248)\end{array}$ & $\begin{array}{l}-0.0373 \\
(0.0328)\end{array}$ \\
\hline Population - adjusted openness & - & - & $\begin{array}{c}0.0084^{*} \\
(0.0043)\end{array}$ & $\begin{array}{l}0.0248^{* * *} \\
(0.0089)\end{array}$ \\
\hline Terms of trade growth & - & - & $\begin{array}{c}0.0342 \\
(0.0299)\end{array}$ & $\begin{array}{c}0.0300 \\
(0.0318)\end{array}$ \\
\hline Democracy indicator & - & - & $\begin{array}{c}0.0546^{*} \\
(0.0288)\end{array}$ & $\begin{array}{c}0.0464 \\
(0.0388)\end{array}$ \\
\hline Democracy squared & - & - & $\begin{array}{l}-0.0387 \\
(0.0257)\end{array}$ & $\begin{array}{l}-0.0384 \\
(0.0349)\end{array}$ \\
\hline Inflation Rate & - & - & $\begin{array}{c}-0.0032^{* *} \\
(0.0014)\end{array}$ & $\begin{array}{c}-0.0032^{* *} \\
(0.0013) \\
\end{array}$ \\
\hline Countries & 163 & 163 & 129 & 129 \\
\hline Observations & 1395 & 1395 & 896 & 896 \\
\hline $\mathrm{R}^{2}$ & 0.0902 & 0.3638 & 0.2968 & 0.5563 \\
\hline Longest Time Series & $1966-2010$ & $1966-2010$ & $1976-2010$ & $1976-2010$ \\
\hline
\end{tabular}

Notes: Asterisks $\left({ }^{*},{ }^{* *},{ }^{* *}\right)$ indicate the statistical significance level $(10 \%, 5 \%, 1 \%)$ of the coefficients. Figures in parentheses are robust standard errors, calculated by allowing errors to be correlated over time within countries. The equations are estimated over non-overlapping five-year periods. The dependent variable is expressed in USD at fixed 2010 PPPs. GDP per capita, the reciprocal of life expectancy at birth, the total fertility rate and female and male schooling attainment for persons aged 15 and over are lagged one period (five years). Other variables are five-year moving averages. All equations are estimated with OLS and include time fixed effects. See Table A2.1 in Appendix 2 for data sources.

Figure 3. Rule of law

Index for the last period used in estimation (2006 to 2010), higher is better

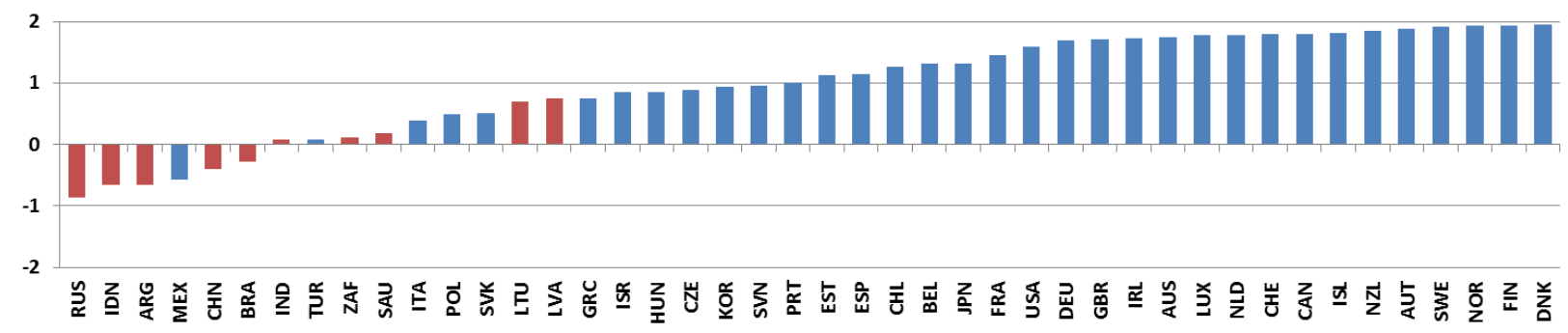


Source: World Bank Worldwide Governance Indicators database. See Figure A2.2 for all countries in the final regression sample and Appendix 7 for why this indicator was chosen among the various governance variables that exist.

Figure 4. Population-adjusted trade openness

Index for the last period used in estimation (2006-10), positive values mean that a country trades more than predicted by its population size

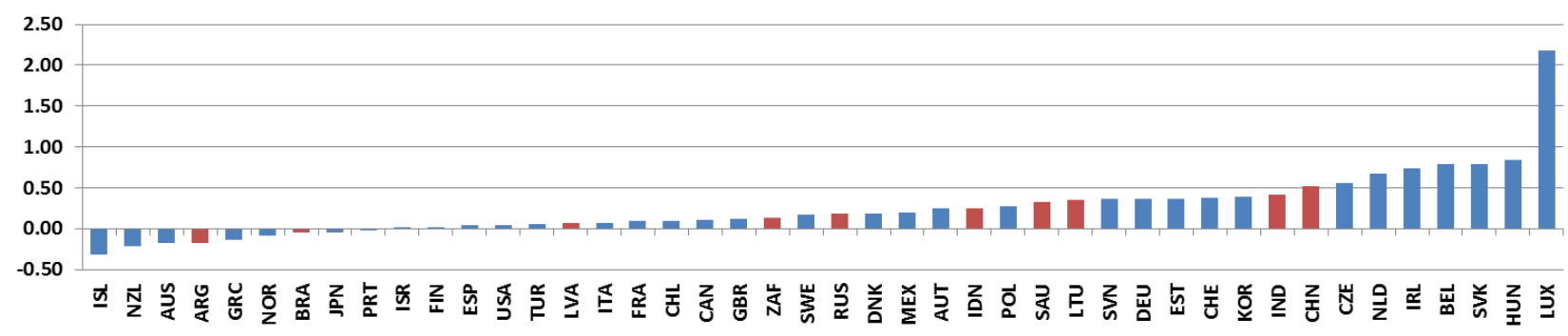

Source: Penn World Tables v8.1 (see Appendix 2).

14. The replication of Barro's results is not exact because of some differences in country coverage and variable definitions and because of a somewhat shorter estimation period, but the results are similar. The explanatory variables that have the highest statistical significance in both Barro's equations and the replications are mostly the same, and often larger in the latter, in particular life expectancy, rule of law, openness, inflation and the investment ratio. Variables found to be less significant in both versions, such as government consumption and democracy indicators, are also closely replicated. Most notably, the estimated equations replicate one of the main findings of much of Barro's recent work on growth: the existence of an 'iron-law' for the speed of convergence of about $2 \%$, as seen from the coefficient on the lagged dependent variable in model 3. The finding mentioned above, that the convergence speed is substantially overestimated when country fixed effects are included in the regression, is apparent when comparing models 3 and 4 .

\subsection{Switching the dependent variable to labour productivity}

15. From a theoretical perspective, in standard growth models (e.g. the Solow-Swan growth model) the capital-to-output ratio eventually stabilises and long-run gains in living standards become entirely driven by productivity growth. From an empirical perspective, even differences in capital intensity levels across countries are relatively minor. As Jones (2015) shows, “...the capital-output ratio is remarkably stable across countries" and "...differences in physical capital contribute almost nothing to differences in GDP per worker across countries." Therefore, conditional convergence in GDP per capita should imply conditional convergence in labour efficiency. Before fitting a labour efficiency model, however, the next stage in the analysis is an incremental shift from explaining GDP per capita (as in Barro's specification) to labour productivity (GDP per worker), which makes it easier to understand why estimated coefficients change as the productivity concept changes (Table 2). Then, a series of further tests are conducted for the inclusion of additional variables which are thought to be desirable given their policy relevance. Country fixed effects are not used in the main specifications for the reasons discussed previously, but Appendix 6 on robustness presents the results of some specifications with fixed effects. ${ }^{7}$

7. Given that the exclusion of country fixed effects constitutes an omitted variable misspecification, one should keep in mind that the convergence rates estimated below may be slightly downward-biased. 
ECO/WKP(2017)17

Table 2. Regressions for conditional convergence in labour productivity

Dependent variable: Annual growth rate of GDP per employee in USD at fixed PPPs averaged over five-year periods

\begin{tabular}{|c|c|c|c|c|c|c|c|}
\hline & $(1)$ & $(2)$ & (3) & $(4)$ & $(5)$ & (6) & $(7)$ \\
\hline log(Lagged labour productivity) & $\begin{array}{l}-0.019^{\star \star \star} \\
(0.0020)\end{array}$ & $\begin{array}{l}-0.012^{\star \star \star} \\
(0.0020)\end{array}$ & $\begin{array}{l}-0.015^{\star \star \star} \\
(0.0020)\end{array}$ & $\begin{array}{l}-0.015^{\star \star \star} \\
(0.0020)\end{array}$ & $\begin{array}{l}-0.015^{\star \star \star} \\
(0.0020)\end{array}$ & $\begin{array}{l}-0.020^{\star \star *} \\
(0.0019)\end{array}$ & $\begin{array}{c}-0.019^{* * *} \\
(0.0019)\end{array}$ \\
\hline $1 /$ (Life expectancy at birth) & $\begin{array}{c}-4.792^{\star \star \star} \\
(0.7408)\end{array}$ & & & & & & \\
\hline Investment ratio & $\begin{array}{l}0.075^{\star * *} \\
(0.0200)\end{array}$ & $\begin{array}{l}0.098^{* * *} \\
(0.0219)\end{array}$ & $\begin{array}{l}0.100^{\star * *} \\
(0.0213)\end{array}$ & $\begin{array}{l}0.097^{* * *} \\
(0.0211)\end{array}$ & $\begin{array}{l}0.097^{\star * *} \\
(0.0214)\end{array}$ & $\begin{array}{l}0.081^{* * *} \\
(0.0198)\end{array}$ & $\begin{array}{l}0.083^{\star * *} \\
(0.0189)\end{array}$ \\
\hline Rule of law & $\begin{array}{l}0.005^{\star * *} \\
(0.0016)\end{array}$ & $\begin{array}{l}0.008^{* * *} \\
(0.0016)\end{array}$ & $\begin{array}{c}0.004^{\star *} \\
(0.0018)\end{array}$ & $\begin{array}{c}0.003^{*} \\
(0.0019)\end{array}$ & $\begin{array}{c}0.002 \\
(0.0021)\end{array}$ & $\begin{array}{l}0.096^{* * *} \\
(0.0131)\end{array}$ & $\begin{array}{l}0.074^{* *} \\
(0.0175)\end{array}$ \\
\hline Population-adjusted openness & $\begin{array}{l}0.007^{* * *} \\
(0.0028)\end{array}$ & $\begin{array}{c}0.007^{\star *} \\
(0.0035)\end{array}$ & $\begin{array}{c}0.008^{* *} \\
(0.0029)\end{array}$ & $\begin{array}{c}0.007^{\star \star} \\
(0.0028)\end{array}$ & $\begin{array}{c}0.006^{\star \star} \\
(0.0029)\end{array}$ & $\begin{array}{l}0.006^{\star * *} \\
(0.0021)\end{array}$ & $\begin{array}{c}0.068^{*} \\
(0.0360)\end{array}$ \\
\hline Human capital & & & $\begin{array}{l}0.014^{\star * *} \\
(0.0037)\end{array}$ & $\begin{array}{l}0.015^{* * *} \\
(0.0038)\end{array}$ & $\begin{array}{l}0.014^{* * *} \\
(0.0039)\end{array}$ & $\begin{array}{l}0.014^{* * *} \\
(0.0037)\end{array}$ & $\begin{array}{l}0.013^{* * *} \\
(0.0036)\end{array}$ \\
\hline Low and stable inflation & & & & $\begin{array}{c}0.001^{*} \\
(0.0006)\end{array}$ & $\begin{array}{c}0.001^{*} \\
(0.0007)\end{array}$ & $\begin{array}{l}0.002^{* * *} \\
(0.0006)\end{array}$ & $\begin{array}{c}0.001^{* *} \\
(0.0006)\end{array}$ \\
\hline Product market regulation & & & & & $\begin{array}{c}-0.003 \\
(0.0029)\end{array}$ & $\begin{array}{c}-0.005^{\star} \\
(0.0025)\end{array}$ & $\begin{array}{l}-0.006^{* *} \\
(0.0026)\end{array}$ \\
\hline $\begin{array}{l}\text { Rule of law * } \\
\text { log(Lagqed labour productivity) }\end{array}$ & & & & & & $\begin{array}{l}-0.009^{* * *} \\
(0.0012)\end{array}$ & $\begin{array}{l}-0.007^{* * *} \\
(0.0017)\end{array}$ \\
\hline $\begin{array}{l}\text { Population-adjusted openness * } \\
\text { log(Lagged labour productivity) }\end{array}$ & & & & & & & $\begin{array}{l}-0.006^{*} \\
(0.0033)\end{array}$ \\
\hline Longest time period & $1966-2010$ & $1966-2010$ & $1966-2010$ & $1966-2010$ & $1966-2010$ & $1966-2010$ & $1966-2010$ \\
\hline Adjusted R-squared & 0.313 & 0.233 & 0.262 & 0.266 & 0.266 & 0.329 & 0.334 \\
\hline Observations & 722 & 722 & 722 & 722 & 722 & 722 & 722 \\
\hline Countries & 121 & 121 & 121 & 121 & 121 & 121 & 121 \\
\hline
\end{tabular}

Notes: Asterisks $\left({ }^{*},{ }^{* *},{ }^{* * *}\right)$ indicate the statistical significance level $(10 \%, 5 \%, 1 \%)$ of the coefficients. Figures in parentheses are standard errors (White) robust to arbitrary heteroskedasticity and within-country serial correlation. All equations are estimated over non-overlapping five-year periods and all variables are period averages (NAs are not propagated) except for the (lagged) level of labour productivity which is the end-of-period value. The dependent variable is expressed in USD at fixed 2010 Purchasing Power Parity. All equations are estimated with OLS and include time fixed effects but no country fixed effects other than dummy variables for Norway and Russia. A test (Kao) for cointegration between the level of labour productivity and its determinants rejects the null hypothesis of no cointegration at the $1 \%$ level in all equations. See Table A2.1 in Appendix 2 for data sources.

16. In column 1, the variables from Barro's original specification that were found to be consistently statistically significant and robust - life expectancy, rule of law, ${ }^{8}$ the investment share and openness - are kept. They all retain large and statistically significant effects on labour productivity, which is not surprising, except perhaps in the case of life expectancy. A shorter average lifespan intuitively leads to lower GDP per capita if it disproportionately affects prime-age workers and thus the size of the workforce relative to the total population (e.g. AIDS in South Africa). However, that shorter lives should affect productivity of the average worker is less clear. A less healthy workforce may well be less productive and have lower life expectancy, but then life expectancy would affect productivity only insofar as it proxies for general health. Further estimations (not shown) reveal that the life expectancy effect is driven partly by the highly non-linear form (reciprocal) in which the variable enters the equation, but mostly by the several countries in the sample with relatively low life expectancies. When assuming a linear effect and removing from the sample countries with fewer than 60 years of life expectancy (so removing about 20 countries), the estimated effect becomes statistically indistinguishable from zero. Furthermore, according to column 1, increasing life expectancy in a very poor country from 50 to 51 would be estimated to boost long-run productivity by $10 \%$, but the same one-year increase in an OECD country where life expectancy is already

8. The World Bank rule of law indicator is closely correlated with other World Bank governance indicators (Langbein and Knack, 2010); however Kaufmann and Kraay (2002) use it as a preferred measure of governance in estimations because it corresponds most closely to the concept of protection of property rights which has been widely used in the literature. See Appendix 7 for more details. 
around 80 years would raise long-run productivity by less than $4 \%$. Given that the long-term model in which the estimated equation will be inserted includes only one country with less than 60 years of life expectancy (South Africa), this variable is dropped from subsequent specifications. As can be seen from column 2, removing life expectancy from the regressors increases the size of the rule of law effect and lowers the estimated speed of convergence.

\subsubsection{A different measure of human capital}

17. Given the importance of human capital in much of the theoretical literature, the absence of any statistically significant and reasonably-sized effect from years of schooling is a disappointing result in much of the empirical literature on growth, including in Barro's results as replicated above. The reasons for this are unclear, but may be related to measurement issues, including the difficulty of assessing the quality, as well as the quantity, of schooling (de la Fuente and Doménech, 2000; Pritchett, 2000). Some further experimentation reveals that a measure of human capital based on average educational attainment in the population but featuring decreasing marginal returns to additional years of schooling (Figure 5 and Appendix 5) is the most successful in producing correctly-signed and statistically significant effects in the labour productivity equations. When added in column 3 , this human capital measure is correctly signed and highly statistically significant. Together with the assumed transformation of years of schooling into human capital, the coefficient in column 3 implies that a one-year increase in average schooling attainment from the sample mean of 8.5 years to 9.5 years would boost long-run labour productivity by $22 \%$. In the old framework where human capital entered the production function explicitly as a factor of production, the impact would have been $38 \%$.

Figure 5. Measure of human capital based on educational attainment

Index for the last period used in estimation (2006 to 2010), higher is better

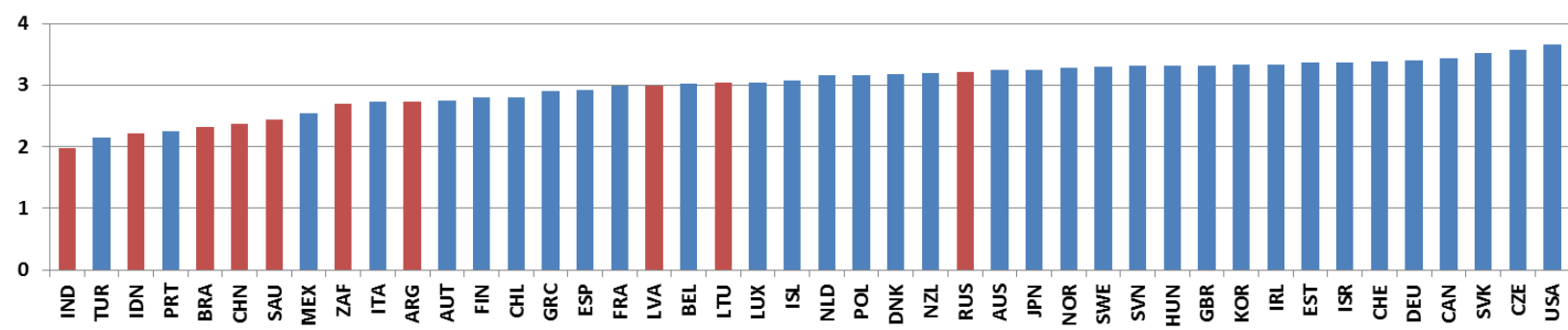

Source: Barro and Lee (2013) based on Morrison and Murtin (2010) (see Appendix 5).

\subsubsection{A different measure of inflation}

18. The regressions replicating Barro's in Table 1 used a simple measure of consumer price inflation and found that higher inflation is associated with worse long-term outcomes, which is not surprising given the large amount of evidence for the benefits of low inflation underpinning the mandates of most central banks in the OECD. Most macroeconomists would agree that in addition to a low average rate, it is also helpful if inflation is as stable as possible, as predictability helps households and firms to make intertemporal trade-offs with a greater degree of certainty. To capture both features of the macroeconomic environment, an index for low and stable inflation was constructed giving equal weighs to both features of the inflation process. More specifically, a low-inflation index is calculated using the following formula:

$$
\text { Index }=\frac{V_{\max }-\left|\pi_{t}-2\right|}{V_{\max }-V_{\min }} \cdot 10
$$

where $\pi_{t}$ is the annual rate of inflation using the consumer price index (CPI) and $V_{\min }$ and $V_{\max }$ are set at $0 \%$ and $50 \%$, respectively. This formula produces a rating between zero and 10 . Countries with exactly $2 \%$ 
inflation earn a rating of 10 . As the inflation rate moves toward 50\%, the rating moves toward zero. A zero rating is assigned to all countries with an inflation rate of $50 \%$ or more. Inflation below $2 \%$ is penalised symmetrically. A similar formula is applied to derive an index for the stability of inflation, except that the second term in the numerator of [3] is a five-year moving average of the standard deviation of inflation and $V_{\min }$ and $V_{\max }$ are set at $0 \%$ and $25 \%$, respectively. A perfect 10 results when there is no variation in the rate of inflation over the five-year period. The rating declines toward zero as the standard deviation of inflation approaches $25 \%$. The overall index for low and stable inflation used in the regressions is then computed as an equally-weighted average of the two sub-indices and varies between 0 and 10 (Figure 6). When the variable is added in column 4, it has a positive effect as expected. A one-point increase in the index would boost labour productivity by about $7 \%$ once full convergence is achieved.

Figure 6. Low and stable inflation

Index for the last period used in estimation (2006-10), higher is better

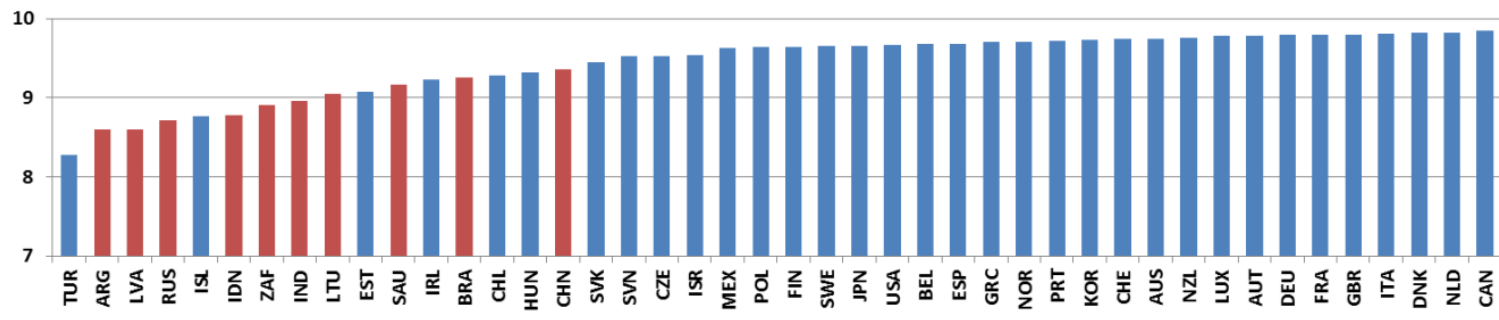

Source: World Bank World Development Indicators database. See Figure A2.4 for all countries used in the final regression sample.

\subsubsection{Adding a measure of product market regulation}

19. A key area of interest to the work of the Economics Department is the role of product market regulation and competition on productivity. No such variable is included in Barro's regressions, probably because of the unavailability of a time series covering both a long-enough time-span and a sufficiently large number of countries. Previous OECD work has sometimes used an indicator of regulation in the network industries (Electricity, Transport and Communications, ETCR) as a proxy for product market regulation given its availability over a long time span, but this indicator is only available for OECD countries. Because including a product market regulation measure in the estimations necessitates the construction of proxy indicators for many countries and years no matter which indicator is used, the superior OECD Product Market Regulation (PMR) indicator is chosen for the current estimation work. Official estimates are used when available and proxy measures are constructed for missing years and countries using a prediction model (Figure 7). The prediction equation correlates official PMR measures with the World Bank's Regulatory Quality indicator for countries and years when both are available, and is used to predict PMR when only Regulatory Quality is available (Appendix 4). When the resulting variable is added in column 5, its estimated coefficient is correctly signed but not statistically significant. Its size indicates that a one-point fall in the PMR indicator would boost long-run labour productivity by roughly $20 \%$ after full convergence. 
Figure 7. Product Market Regulation

Official and proxy indices for the last period used in estimation (2006-10), higher value means more stringent regulation

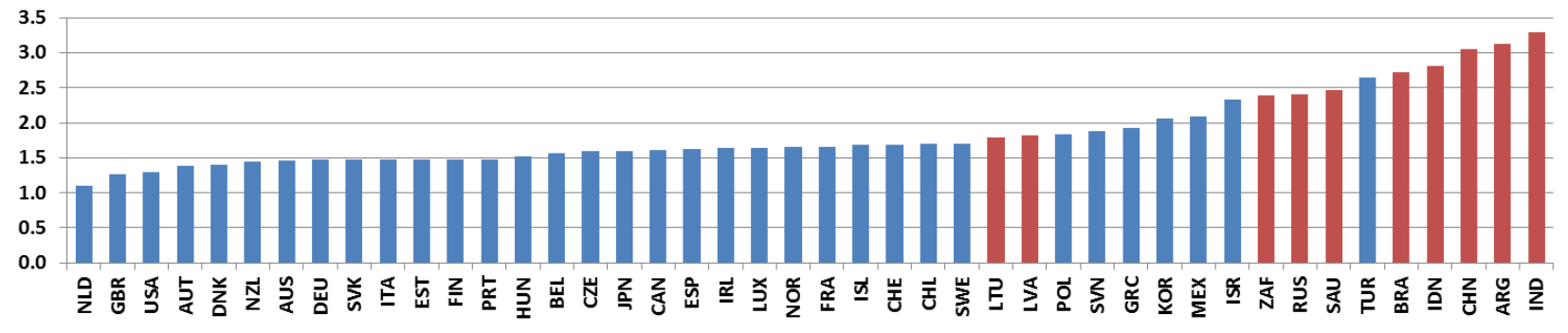

Source: OECD Product Market Regulation database (see Koske et al., 2015) (see Appendix 4).

\subsubsection{Checking if policy indicators affect the speed of convergence}

20. An important question is whether the speed at which conditional convergence happens is the same across countries or is influenced by policy settings. Already, the previous labour efficiency convergence equation in [2] made the speed of convergence a function of openness. Moreover, Westmore (2013) and Andrews and Westmore (2014) augment this equation and show that an economy's speed of convergence is an increasing function of two enabling factors: managerial quality and business R\&D expenditure. Limited data availability prevents these two particular indicators from being tested in the current estimation framework. ${ }^{9}$ Still, among the variables used so far in the estimations, rule of law and openness might plausibly influence the convergence speed. Better protection of property rights and more easily-enforceable contracts in general could make countries better able to absorb existing technology and thus speed up convergence. Similarly, countries that are more open and exposed to foreign technology and competition might have both greater incentives and opportunities to move up the technology ladder.

21. While recognising the difficulty of empirically disentangling equilibrium level effects from speed of convergence effects, the existence of such effects can be tested by adding interaction effects to the original estimation equation in [2]. The new equation can be expressed in error-correction form as:

$$
\Delta y_{i, t}=\gamma_{t}+\left(\rho_{1}+\sum_{j=1}^{J} \rho_{j} \boldsymbol{X}_{i, t-1, j}\right)\left(y_{i, t-1}-\alpha-\sum_{k=1}^{K} \widehat{\boldsymbol{\beta}}_{k} \boldsymbol{X}_{i, t-1, k}\right)+\varepsilon_{i, t}
$$

where $\rho_{1}$ is the base speed of convergence and $\rho_{j}$ measures the effect of indicator $j$ on this speed, with $J \subseteq K$. Columns 6 and 7 of Table 2 report the results of estimating [4] with rule of law and openness influencing the speed of convergence. ${ }^{10}$ The negative and statistically significant coefficients on the interaction effect between rule of law and the lagged dependent variable in column 6 , and between both rule of law and openness and the lagged dependent variable in column 7, provide some evidence that better adherence to the rule of law and greater openness speed up convergence. For a country with a strong rule

9. Data on business R\&D spending is available from the Science and Technology directorate (STI) for only about 30 countries, and this variable was not found to be statistically significant when tested within the current framework. Also, the data on managerial quality used by Andrews and Westmore (2014) are available for only 20 countries.

10. In these equations, the indicators being interacted with lagged labour efficiency were de-meaned to prevent the estimated base speed of convergence $\left(\hat{\rho}_{1}\right)$ from being re-scaled. This estimated base speed now corresponds to the convergence speed that would occur if interaction effects were zero (i.e. at the sample means for rule of law and openness). 
of law (represented by an indicator value of 1.5, which is typical of OECD countries) the convergence speed would be $3.4 \%$, whereas for a country with a weaker rule of law (an indicator value of zero, more typical of the BRICS countries) the convergence speed would be $2 \%$, using the results of column 6 .

22. These results are supported by a two-step estimation procedure: first estimating the long-term relationship and recovering the associated residuals, corresponding to the expression in the second set of parentheses in [4], and then estimating speed-of-convergence effects in a second-stage regression. This alternative method has the advantage of keeping long-term effects $\left(\widehat{\boldsymbol{\beta}}_{k}\right)$ independent of any interaction terms on the speed of convergence, thus providing a robustness check on the one-step method. Estimation results from the two-step method are broadly consistent with those from the one-step procedure. The only notable difference is that openness has a smaller effect on the equilibrium level of productivity in the first stage, but a larger effect on the speed of convergence in the second stage.

\subsection{Switching the dependent variable to labour efficiency}

23. After GDP per capita and labour productivity, the final step in the progression through dependent variables is to use labour efficiency, the productivity concept to which the estimated equation will apply in the long-term model. However, historical estimates of labour efficiency are produced by the Economics Department, following the method outlined in section 2.1, only for the 46 countries included in the longterm model. To have as large a sample as possible, the labour efficiency estimates used in this section are obtained following the same decomposition methodology but sourcing the data from the PWT (v8.1), the same source that was used for GDP per capita and labour productivity in the estimations above. The downside is that the PWT series end in 2011 and do not perfectly match the EO estimates, an issue that will be taken up below when discussing the transition from an estimated equation to a projection equation for the long-term model.

24. Column 1 in Table 3 uses the same specification as column 7 in Table 2, except that the dependent variable is now labour efficiency growth. Reassuringly, the coefficient estimates are little changed, except for the investment ratio's, which falls by a factor between two and three and is no longer statistically significant. This finding is intuitive: if workers are given more capital to work with, labour productivity is expected to increase, but not labour efficiency as it is purged of the effect of capital intensity. While investment might embody recent technical progress and so boost labour efficiency, little robust empirical evidence supports this effect. Column 2 therefore drops the investment ratio from the list of regressors, and other coefficient estimates barely change. This equation provides a basis for testing two different measures of innovation and one measure of income inequality. As the time and country coverage of the new variables are limited relative to the other regressors and to ensure coherence with the influence of variables estimated on the full sample, the coefficient estimates of the variables with a wider coverage are constrained to remain as estimated in column 2. 
Table 3. Regressions for conditional convergence in labour efficiency

Dependent variable: Annual growth rate of labour efficiency in USD at fixed PPPs averaged over five-year periods

\begin{tabular}{|c|c|c|c|c|c|c|}
\hline & $(1)$ & $(2)$ & (2a) & (2b) & $(2 \mathrm{c})$ & (3) \\
\hline log(Lagged labour efficiency) & $\begin{array}{l}-0.024^{* * *} \\
(0.0022)\end{array}$ & $\begin{array}{l}-0.024^{\star * *} \\
(0.0022)\end{array}$ & -0.024 & -0.024 & -0.024 & $\begin{array}{l}-0.019^{* * *} \\
(0.0025)\end{array}$ \\
\hline Investment ratio & $\begin{array}{c}0.031 \\
(0.0221)\end{array}$ & & & & & \\
\hline Rule of law & $\begin{array}{l}0.085^{\star * *} \\
(0.0161)\end{array}$ & $\begin{array}{l}0.090^{\star \star *} \\
(0.0156)\end{array}$ & 0.090 & 0.090 & 0.090 & $\begin{array}{c}0.004 \\
(0.0023)\end{array}$ \\
\hline Population-adjusted openness & $\begin{array}{c}0.076^{*} \\
(0.0390)\end{array}$ & $\begin{array}{l}0.080^{* *} \\
(0.0387)\end{array}$ & 0.080 & 0.080 & 0.080 & $\begin{array}{l}0.011^{* * *} \\
(0.0023)\end{array}$ \\
\hline Human capital & $\begin{array}{l}0.017^{\star * *} \\
(0.0042)\end{array}$ & $\begin{array}{l}0.017^{* * *} \\
(0.0042)\end{array}$ & 0.017 & 0.017 & 0.017 & $\begin{array}{l}0.018^{* \star *} \\
(0.0044)\end{array}$ \\
\hline Low and stable inflation & $\begin{array}{l}0.002^{* * *} \\
(0.0007)\end{array}$ & $\begin{array}{l}0.002^{* * *} \\
(0.0007)\end{array}$ & 0.002 & 0.002 & 0.002 & $\begin{array}{l}0.002^{* *} \\
(0.0008)\end{array}$ \\
\hline Product market regulation & $\begin{array}{l}-0.006^{\star *} \\
(0.0027)\end{array}$ & $\begin{array}{l}-0.006^{\star *} \\
(0.0027)\end{array}$ & -0.006 & -0.006 & -0.006 & $\begin{array}{l}-0.005 \\
(0.0032)\end{array}$ \\
\hline R\&D expenditures, $\%$ of GDP & & & $\begin{array}{c}-0.002 \\
(0.0015)\end{array}$ & & & \\
\hline Patent applications per 1000 pop & & & & $\begin{array}{l}-0.000 \\
(0.0000)\end{array}$ & & \\
\hline Income inequality (GINI index) & & & & & $\begin{array}{l}-0.0003^{\star *} \\
(0.00014)\end{array}$ & \\
\hline $\begin{array}{l}\text { Rule of law* } \\
\text { log(Lagged labour efficiency) }\end{array}$ & $\begin{array}{l}-0.008^{* * *} \\
(0.0016)\end{array}$ & $\begin{array}{l}-0.009^{\star * *} \\
(0.0016)\end{array}$ & -0.009 & -0.009 & -0.009 & \\
\hline $\begin{array}{l}\text { Population-adjusted openness * } \\
\text { log(Lagged labour efficiency) }\end{array}$ & $\begin{array}{l}-0.007^{*} \\
(0.0037) \\
\end{array}$ & $\begin{array}{l}-0.007^{*} \\
(0.0037) \\
\end{array}$ & -0.007 & -0.007 & -0.007 & \\
\hline Longest time period & $1966-2010$ & $1966-2010$ & $1996-2010$ & $1966-2010$ & $1981-2010$ & $1966-2010$ \\
\hline Adjusted R-squared & 0.300 & 0.298 & 0.306 & 0.293 & 0.292 & 0.241 \\
\hline Observations & 722 & 722 & 244 & 627 & 373 & 722 \\
\hline Countries & 121 & 121 & 99 & 104 & 108 & 121 \\
\hline
\end{tabular}

Notes: Asterisks $\left({ }^{*},{ }^{* *},{ }^{* * *}\right)$ indicate the statistical significance level $(10 \%, 5 \%, 1 \%)$ of the coefficients. Figures in parentheses are standard errors (White) robust to arbitrary heteroskedasticity and within-country serial correlation. All equations are estimated over non-overlapping five-year periods and all variables are period averages (NAs are not propagated) except for the (lagged) level of labour efficiency which is the end-of-period value. The dependent variable is expressed in USD at fixed 2010 Purchasing Power Parity. All equations are estimated with OLS and include time fixed effects but no country fixed effects other than dummy variables for Norway and Russia. Coefficients in italics were imposed rather than estimated. A test (Kao) for cointegration between the level of labour efficiency and its determinants rejects the null hypothesis of no cointegration at the $1 \%$ level in all equations. See Table A2.1 in Appendix 2 for data sources.

\subsubsection{Adding a measure of innovation}

25. The great bulk of economic growth at any point in time is due to replication of established technologies and best practices. Replication happens through the accumulation of capital embodying existing technologies as well as through the diffusion of best practices and methods in management, organisation, etc. Such replication and diffusion is thought to be one of the primary ways in which developing economies catch-up with those at the frontier (Rodrik, 2011). Nevertheless, innovation at the frontier is vital to sustaining gains in productivity and standards of living in the long-run. Two different measures of innovation intensity are tested in columns $2 \mathrm{a}$ and $2 \mathrm{~b}$. The first is total R\&D expenditures as a share of GDP (Figure 8) and the second is the total number of patent applications by residents and nonresidents per 1000 population (Figure 9). Neither measure has an effect on labour efficiency that is statistically distinguishable from zero in the estimated models. 
Figure 8. Measure of innovation based on R\&D expenditures

Total R\&D expenditures as \% of GDP in the last estimation period (2006-10)

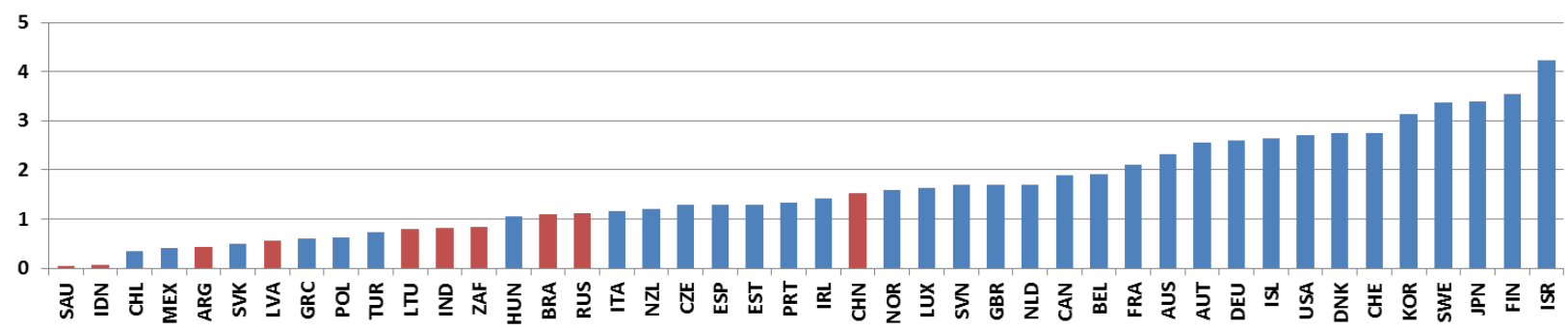

Source: World Bank's World Development Indicators (WDI). See Figure A2.5 for all countries in the sample.

Figure 9. Measure of innovation based on patent applications

Total patent applications by residents and non-residents per thousand population in the last estimation period (2006-10), log scale

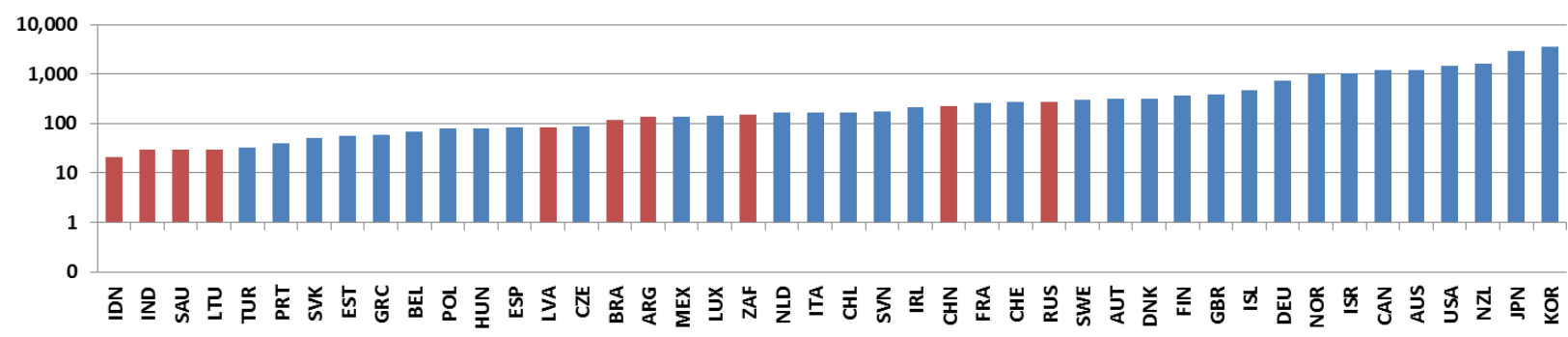

Source: World Bank's World Development Indicators (WDI). See Figure A2.6 for all countries in the sample.

26. One reason for this finding may be that innovation does not matter everywhere equally. Indeed, innovation ought to become more important for productivity growth as countries get richer and closer to the global technology frontier. Such countries have fewer opportunities for catch-up, because the low-lying apples of replication have already been seized. They have more to gain from pushing the frontier outward by innovating at the frontier. Égert (2016) indeed finds suggestive evidence that innovation intensity takes on greater importance for more developed countries: in a range of regression models on different samples, he finds that the coefficient on some innovation measures almost doubles when the sample is narrowed down from the 34 OECD countries to a subset of the most developed economies. To account for distance to the frontier, both measures of innovation were interacted with the ratio of a country's labour efficiency level to that of the United States in the relevant year (measured at purchasing power parity). But results (not shown) were no better than with the raw measures. Other variables based on public and private R\&D spending, as well as other data sources on patents, were tried (results not shown) but did not yield statistically significant effects, and typically cut down the sample size even more.

27. Another reason why the innovation indicators tested do not perform well could be that they are flow measures, whereas it seems more intuitive that it should be the accumulated stock of technology that matters for labour efficiency. Moreover, as the replication argument makes clear, countries do not just draw on internally-generated technologies to improve their prospects, they can also draw on a large foreign stock of technologies. The role of the innovation process in driving labour efficiency convergence is therefore incorporated into the long-term simulation model via accumulation equations for the stock of domestic and foreign technologies. Specifically, data on R\&D expenditures as a share of GDP in country $i$ 
and year $t\left(R D_{-} E_{i, t}\right)$ are used to construct a domestic stock of $\mathrm{R} \& \mathrm{D}$ capital $\left(R D_{-} K_{i, t}\right)$ according to the usual stock-flow equation:

$$
R D_{-} K_{i, t}=(1-\delta) R D_{-} K_{i, t-1}+R D_{-} E_{i, t}
$$

where $\delta$ is the depreciation rate, assumed to be $5 \%$, a figure at the upper end of the range estimated using direct observations by Rassenfosse and Jaffe (2017), but at the lower end of previous estimates. For simplicity, and because R\&D expenditure series have short histories for many countries, stocks are initialised for the simulations by assuming that they are in a steady-state, given the assumed depreciation rate and a moving average of the last few observations on R\&D expenditures. In other words, initial stocks are set so that observed $R \& D$ expenditures just cover depreciation. Hence, initial stocks are proportional to recent average levels of $R \& D$ spending across countries. Then, a global stock of $R \& D$ is constructed by summing domestic stocks across countries, all measured in USD at 2010 PPPs. Both stock variables are then added to the estimated long-run labour efficiency equation, with elasticities drawn from a recent metaanalysis of the effects of R\&D capital on productivity (Donselaar and Koopmans, 2016). They are 0.135 for the (log) domestic R\&D stock and 0.154 for the $(\log )$ global stock. ${ }^{11}$ These productivity elasticities imply output elasticities not far from the 0.11 reported in Bom and Ligthart's (2014) literature review for an increase in public capital, and indeed R\&D can be thought of as public capital.

28. This implementation ensures that a country's equilibrium labour efficiency level increases when innovation intensity rises above the level needed to cover depreciation. An increase in a small country's R\&D stock, if it is maintained through continued investment, boosts that country's equilibrium labour efficiency level, but as it contributes little to raising the global R\&D stock, foreign economies are not much affected. On the other hand, the global stock of R\&D can rise noticeably when a large economy raises its domestic R\&D capital stock, with externalities on smaller countries' labour efficiency levels. R\&D spending is thus the only variable that will affect both a country's own equilibrium labour efficiency level as well as those of other countries. At the mean initial level of R\&D spending across countries in the model (1.7\% of GDP), the average domestic R\&D capital stock comes out to $34.3 \%$ of GDP. A permanent increase in R\&D spending of 1 percentage point of GDP, which also corresponds to the standard deviation of R\&D spending intensities across the countries in the model, would raise the equilibrium R\&D capital stock by $60 \%$ ( $0.47 \log$ points). Multiplied by the assumed elasticity, this translates into a $6 \%$ gain in equilibrium labour efficiency. A temporary increase in R\&D spending in this setup would only have a transitory effect on labour efficiency growth, first raising it and then depressing it relative to the baseline, with no change in the long-run level.

\subsubsection{Adding a measure of income inequality}

29. A rapidly-expanding body of work suggests that, in addition to being undesirable for its own sake, rising income inequality, at least beyond a certain threshold, may also be bad for growth (Cingano, 2014; Ostry et al., 2014; Dabla-Norris et al., 2015). The mechanisms through which this growth effect would occur are not well understood, but could include health effects on the poor, economic or financial instability, or declining public confidence in policies that boost growth, such as trade openness. The measure of inequality used in column 2c of Table 3 is the World Bank's GINI coefficient (Figure 10). Given limited data coverage, as for the innovation indicators, the effect of this variable on labour efficiency is estimated while constraining coefficients for the other variables to their magnitudes in column 2. Unlike for the R\&D indicators, however, the effect of income inequality is statistically significant and suggests that a 10-point increase in the GINI index would lower long-run labour efficiency by about $13 \%$. Given the estimated speed of convergence, this corresponds to a fall in the average growth

11. The particular elasticities cited come from the subsection of the meta-analysis that uses macro-level studies only (there are 15 such studies). 
rate of GDP by about a fifth of a percentage point per year over the first 25 years. This effect is about six times smaller than that estimated by Cingano (2014). ${ }^{12}$

Figure 10. Measure of income inequality

GINI index used in the last estimation period (2006-10), higher index means greater income inequality

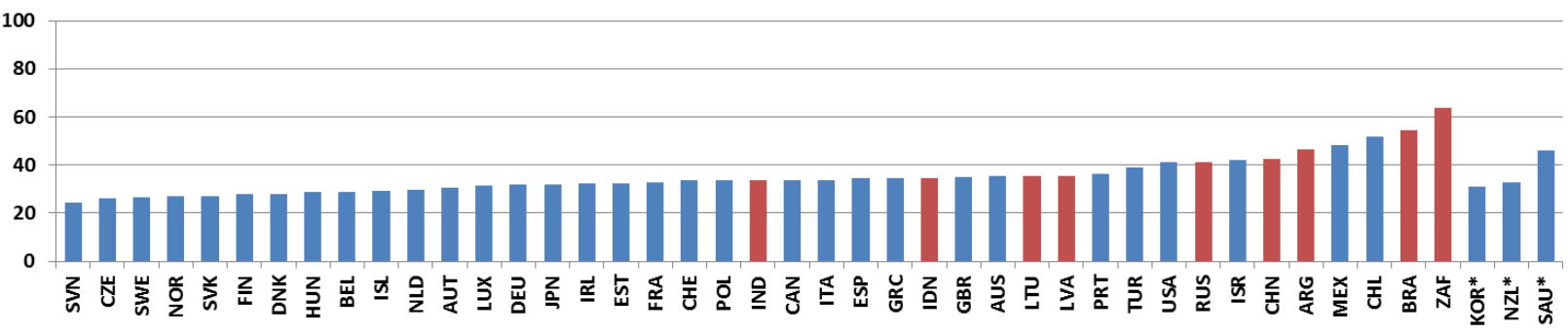

\begin{abstract}
* These indices are from different datasets and years and are not directly comparable to other countries'. The New Zealand and Korean indices are calculated from the Standardized World Income Inequality Database. The index for Saudi Arabia is from the online $\mathrm{CIA}$ World Factbook and refers to 2013. The indices for these three countries were not used in estimation (Table 3) but they will be necessary to initialise the long-term simulations.
\end{abstract}

Sources: World Bank's World Development Indicators (WDI), Standardized World Income Inequality Database and CIA World Factbook. See Figure A2.7 for all countries in the sample.

\title{
3.4.3 A final equation
}

30. For the long-term simulation model, the preferred specification would appear to be column $2 \mathrm{c}$ of Table 3, which is basically column 2 but supplemented by the estimated effect of income inequality on the smaller sample. To this equation would be added the domestic and global R\&D capital stocks as described above, with their associated elasticities. As suggested previously, the coefficient estimates on the terms interacting rule of law and openness with lagged labour efficiency would be interpreted solely as speed-ofconvergence effects, while the long-term effects of structural indicators would be the same no matter the initial level of labour efficiency. A one-standard deviation improvement in the rule of law would raise the convergence speed by 0.9 percentage points (from $2.4 \%$ to $3.3 \%$ per annum) while the corresponding increase in openness would raise it by 0.7 percentage points.

\subsection{Other variables tested and robustness of the preferred equation}

31. As hinted previously, besides the variables appearing in Tables 1 to 3, a large number of other variables were tested in the regression framework. These include most sub-indices from the Fraser Institute's Economic Freedom of the World (EFW) index (including labour market regulation indicators), as well as the World Bank's World Development Indicators (WDI) and Doing Business indicators. Most of these indicators were not retained because they were intuitively wrongly signed, not statistically significant

12. Cingano (2014) finds that a 3-point increase in the GINI index lowers GDP per capita growth by 0.35 percentage point per year on average in the first 25 years. Other estimations (not shown) confirm that the result in column $2 c$ is robust to using different sources for the GINI data. One other source is the Standardized World Income Inequality Database, which has GINI measures for both market income (pretax and transfers) and net income (post-tax and transfers). Counterintuitively, using these measures in column $2 \mathrm{c}$ in place of the World Bank measure yields a larger negative impact for market-income inequality $(-0.00042 * * *)$ than for net-income inequality $\left(-0.00025^{* *}\right)$. The effect estimated using the World Bank's measure (-0.00032**) falls in-between. Also interestingly, the difference between the market and net measures of the GINI index does not have a statistically significant effect, suggesting that the extent of redistribution does not affect growth convergence. 
at conventional levels, or of economically insignificant magnitudes. Often, the lack of a significant correlation may be due to a high level of collinearity between the different variables present in the specification (see Annex Table A2.2). For instance, many indicators of regulatory quality are strongly correlated with the already-included rule of law variable. This is why such a variable is best seen as proxying for a wide range of related institutional characteristics which tend to co-evolve (see Appendix 7). In addition, many variables are available for only a small number of countries, or with limited history, thus shrinking the sample too much for their inclusion in the regression model. Exceptions were made only for the innovation and income inequality indicators. Their inclusion was considered important enough that they were estimated on a small sample, constraining other coefficients to be the same as they were in the large-sample model to insure consistency.

32. One set of indicators that were tried, but ultimately not retained, concerns the age structure of the population. Some studies have found a negative link between the age structure of the population or workforce and an economy's productivity, independent of labour supply effects (Feyrer, 2007 and 2008; Maestas et al., 2016). Such findings would portend some drag on productivity growth in the decades ahead in many countries as the proportion of older workers rises. Other studies have disputed these findings, arguing that productivity effects related to aging are likely to be negligible (National Research Council, 2012; Burtless, 2013). The possible effects of aging were tested in the current framework by adding a set of variables that measure the proportion of the workforce in each ten-year age group from 15-24 to 65-74. They were not found to be economically or statistically significant in explaining labour efficiency growth, and thus were not retained for the preferred equation.

33. Robustness tests for the preferred equation are presented in Appendix 6. Estimated coefficients are reasonably robust to using different estimators. When performing separate regressions on OECD and non-OECD countries, however, the rule of law and human capital effects are different, presumably because OECD countries have generally performed well on both indicators in the sample period and the OECDonly sample therefore exhibits too little cross-country and time variation for identification. Based on some regressions that include country fixed effects, Appendix 6 also further justifies the choice of not including such effects in the equation and explains why the estimated coefficient on the rule of law should be interpreted as reflecting the general quality of institutions and not just the legal environment.

\subsection{Long-term policy effects}

34. The results reported in the regression tables above are not easy to interpret in an intuitive sense. A better way to express them is to calculate the long-term effect of a change in each determinant of interest, that is, the effect on the level of labour efficiency once full convergence has been achieved. To obtain an economically-relevant comparison, it is also useful to calculate these effects for one-standard deviation changes in the different structural indicators, with standard deviations calculated in the crosssectional dimension for the most recent estimation period (2006-2010, see the rightmost columns of Table A2.1 in Appendix 2). These long-term effects illustrate the relative importance of the structural indicators in explaining observed differences in labour efficiency levels across countries (Figure 11, Panel A). But while human capital, for instance, is able to explain a large share of productivity differences across countries, it is not realistic to expect that a given country could improve its human capital by one standard deviation over a short time frame, and likewise for the other productivity determinants. So another useful way to express the relative impacts of improvements in structural indicators is to show the long-term effects of 'typical' changes in these determinants along the time dimension, calculated here as the mean absolute five-year change within countries (Figure 11, Panel B). Except for the inflation indicator, these effects are much smaller than those calculated based on standard deviations across countries. 
Figure 11. Relative influence of productivity determinants

Per cent increase in equilibrium labour efficiency following an improvement in the determinants calibrated on...

A. ...standard deviation across countries

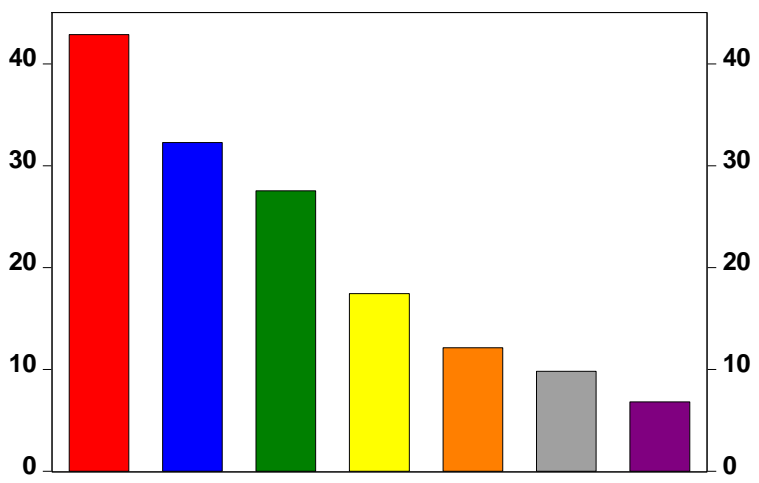

B. ...mean absolute 5-year change within countries

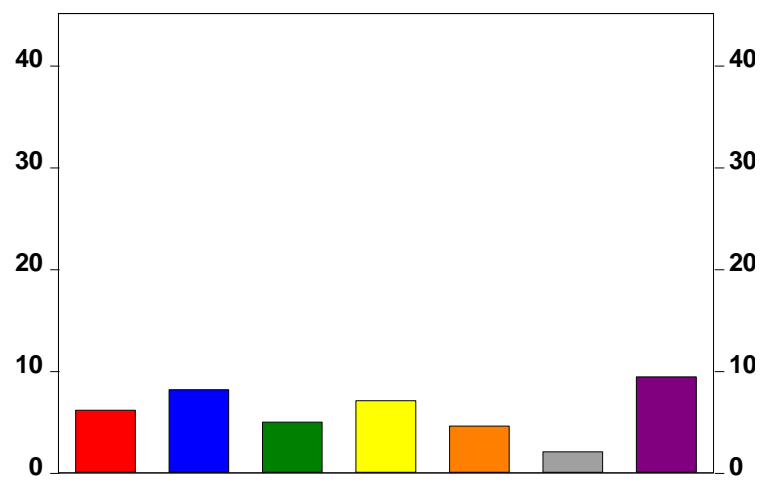

Note: The effects are calculated from the estimates in column $2 c$ of Table 3.

35. Given the low convergence speed, the long-term effects shown in Figure 11 take a long time to be fully phased in. But the near and medium-term effects of shocks are not negligible. Taking the PMR effect as an example, the same-size shock as shown in Figure 11 Panel B (fall of 0.27 points) would immediately raise labour efficiency growth by 0.17 percentage points (Figure 12, Panel A). This growth effect declines gradually thereafter but persists for decades. A third of the full long-term level effect would manifest within 15 years, and half within 30 years. Given the influence of rule of law and openness on the speed of convergence, the dynamics are conditional on the values of these indicators. A weak rule of law for instance could cut the near-term positive effects by a third; and vice-versa for a strong one (Figure 12, Panel B).

Figure 12. Differences from baseline labour efficiency following PMR reform (fall of 0.27 points)

A. With av erage rule of law and openness

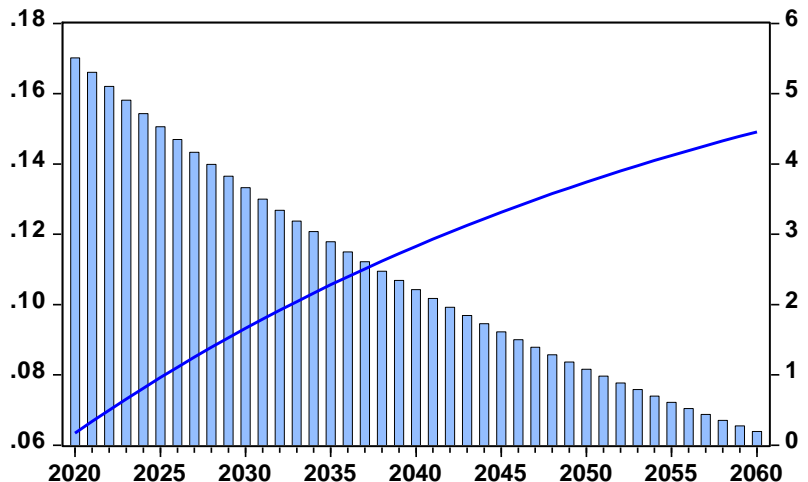

Grow th rate, percentage point (left axis) Level, per cent (right axis)
B. With different rule of law strenghts

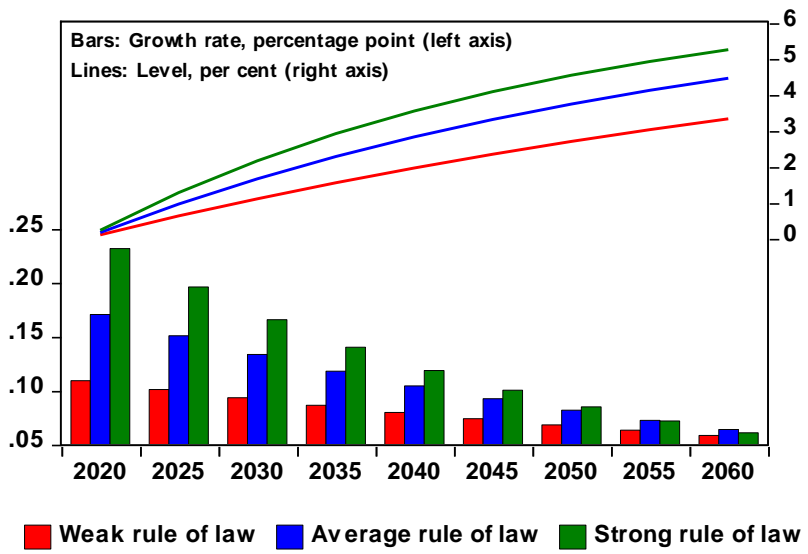

Note: The effects are calculated from the estimates in column $2 \mathrm{c}$ of Table 3. In Panel B, rule of law is lowered by one point relative to the sample average for the 'weak' scenario; and raised by one point for the 'strong' scenario. 


\subsection{Comparison and consistency with other recent OECD work on productivity convergence}

36. Égert (2016) similarly studies the determinants of labour efficiency at the macroeconomic level. He regresses labour efficiency on a set of long-term drivers, including product and labour market regulations, trade openness and innovation intensity. His estimates are also used in the new framework for the quantification of structural reforms (Égert and Gal, 2017). The time period covered is similar. The main difference with the present paper is that he uses data on the 34 OECD countries only. The narrower country coverage has the advantage of allowing a larger number of policy channels to be considered because of greater data availability. The present study, being interested in the factors driving long-term convergence between poor and rich economies, considers a larger set of countries, but at the cost of using a narrower set of productivity determinants. The other main difference is that Égert (2016) includes country fixed effects in most of his estimations. As pointed out above, the inclusion of country fixed effects probably biases the estimated speed of convergence upward, but more importantly, it means that the effects of productivity determinants are identified mostly from variation along the time dimension. As the productivity determinants considered typically exhibit much more cross-country variation than time variation, smaller estimated effects are to be expected, especially for slow-moving variables. Nevertheless, the frameworks are similar enough that the results for the productivity determinants that overlap between the two studies can be roughly compared, keeping in mind the caveats just mentioned, as well as differences in country coverage, estimation periods and the general difficulty of identifying precise and robust effects in panel regression frameworks.

37. The work on quantification of structural reforms uses ETCR to measure product market regulation rather than PMR but, after suitable transformation ${ }^{13}$, the long-run semi-elasticity of labour efficiency to a change in PMR is roughly two to two-and-half times larger in column 2c of Table 3 than reported in Égert and Gal (2017). On the other hand, Andrews and Westmore (2014) obtain effects that are about $60 \%$ larger than estimated here in their baseline model using PMR. The wide dispersion of estimates shows the large uncertainty around effects of PMR reforms on long-run productivity.

38. Other effects that can be compared across OECD productivity convergence studies include those from human capital, population-adjusted openness and innovation. Human capital, based in a similar way on years of schooling, has a positive and statistically significant effect in only a few of Égert's baseline specifications. When it does, the estimates imply that a one-standard deviation increase in human capital raises the long-run level of labour efficiency by about $20 \%$, but this finding is not very robust. The estimate in the preferred equation above implies a $43 \%$ long-run boost. On openness, the results from the work on quantification of structural reforms are much more robust and imply that a one-standard deviation increase raises long-run labour efficiency by between $10 \%$ and $15 \%$. The results above suggest an effect two to three times as large. And regarding innovation, a one-standard deviation increase in Égert's preferred innovation measure (business expenditures on R\&D financed by industry) lifts long-run labour efficiency by between $3 \%$ and $4 \frac{1}{2}$ per cent, whereas the econometric estimates above were not statistically significant. But the assumed elasticity implies a comparable $6 \%$ increase in long-run labour efficiency for a permanent one-standard deviation increase in $R \& D$ spending.

\section{Preliminary labour efficiency projections}

39. This section presents preliminary trend labour efficiency projections based on the equation developed in previous sections. They are preliminary in the sense that methodologies for projecting some of the structural indicators have yet to be developed. From the point of view of the simulation model, most of these variables will be exogenous over the projection period. Two types of simulations are carried out

13. The estimated PMR effect is translated into an ETCR-equivalent effect by assuming that $\triangle P M R=$ $0.45 * \triangle E T C R$, which is based on a simple linear regression between official estimates of both indicators. 
below, first with no change in the explanatory variables, and then with some simple shocks to the main variables of interest. Before moving to projections, however, it is necessary to choose an assumption for the future exogenous global rate of technical progress, corresponding to the first constant $\left(\gamma_{t}\right)$ in [3]. Selecting a value for this parameter is not straightforward and essentially boils down to arbitrating the ongoing debate between Gordon (2016), who argues that the rate of innovation slowed down decades ago and will keep future trend growth in check, and Brynjolfsson and McAfee (2014), who argue that breakthrough technologies will continue to propel economies forward at a healthy clip.

\subsection{The global rate of technological progress}

40. In the old vintage of the long-term model, the rate of labour efficiency growth to which all countries eventually converged was set at $1.3 \%$, corresponding to the average rate of labour efficiency growth observed among advanced economies over the period 1996-2006. ${ }^{14}$ This assumption seems optimistic, for two reasons. First, the average rate observed over history would have included some catchup effects from countries below their long-run equilibriums (which presumably outnumber those above), and not just 'pure' efficiency gains. Second, the conditional convergence framework links the long-run equilibrium to structural characteristics and policies that have generally been improving over time and therefore account for some of the observed historical trend growth. These two caveats suggest that the historical rate is somewhat below $1.3 \%$.

41. In principle, it should be possible to use the estimated time fixed effects to calculate the historical global rate of technical progress which is not explicable by the rest of the model. In practice, however, the fixed effects do not show an intuitive pattern, probably because they also capture any residual cyclical variation in the dependent variable left over after taking five-year period averages, as well as other idiosyncratic time effects.

42. Instead, as is often done in this type of exercise, the global rate of technical progress is calibrated based on historical data for the United States (e.g. Cette, Lecat and Ly-Marin, 2016). OECD estimates suggest that US trend labour efficiency growth has been around $1.1-1.2 \%$ per annum since the crisis, compared to an average of 13/4 per cent over the period 1985-2000. As argued previously, taking recent US growth as the basis for future growth of technical progress could be over-optimistic if, instead of being driven only by technological improvements, it has been driven by improvements in US-specific structural factors. In practice, however, improvements in the structural variables which were found to be most significant in the previous empirical exercise have been very modest over the last decade or more in the United States: the improvement in human capital has averaged less than $0.1 \%$ per annum for the last two decades; openness is around the same level as it was a decade ago; and there is little evidence of improvement in product market regulation or the rule of law. This suggests a neutral baseline assumption for technologically-driven labour efficiency growth slightly below the current trend, about $1 \%$ per annum. The steady-state global rate of technological progress in the long-term model is thus exogenously set at this value. It should be noted that the parameter has little bearing on questions relating to the relative performance of countries, as it affects all countries and scenarios equally.

43. To allow a policy link between research and development spending and technological progress, the global rate of technological growth $\left(\varphi_{t}\right)$ could also be endogenised to the aforementioned global stock of $\mathrm{R} \& \mathrm{D}$ capital $\left(R D_{-} K_{t}^{G}\right)$, with the use of the following equation:

$$
\varphi_{t}=\varphi^{e x o}+\varepsilon \cdot \Delta \log \left(R D_{-} K_{t}^{G}\right)
$$

14. It should be noted however that the labour efficiency concept was different as it was based on a production function that included human capital explicitly as a factor of production (see previous discussion). 
where $\varphi^{\text {exo }}$ is the exogenous assumption just discussed and $\varepsilon$ the assumed elasticity of available technology to the global stock of R\&D (measured as a share of world output). In the steady state, this stock is stable, so the technological growth rate would be the same as in the exogenous case. However, changes in $\mathrm{R} \& \mathrm{D}$ spending intensities, whether permanent or temporary, would make the R\&D stock's growth rate deviate from zero temporarily, thus affecting the global rate of technological progress. Setting $\varepsilon=0.15$, similar to the elasticities discussed previously for the influence of $R \& D$ stocks on productivity levels, would seem reasonable. By way of illustration, a permanent 1 percentage point of GDP increase in R\&D spending in the United States would make the growth rate of the domestic stock of R\&D capital jump to $13 / 4$ per cent immediately and remain above $1 \%$ for the following decade. Simultaneously, the growth rate of the global stock of R\&D would jump to $0.6 \%$ and remain above $0.3 \%$ during the same decade (seeing as the United States is about one fifth of the world total). With the proposed elasticity of 0.15 , this boost to the global stock of knowledge would raise the growth rate of technological progress by 0.08 percentage points at first, and less in the following years.

\subsection{Initial gaps to equilibrium labour efficiency and growth residuals}

44. In the absence of much of the information required to update them, initial gaps relative to country-specific equilibrium labour efficiency levels at the start of the simulation period are assumed equal to what they were at the end of the estimation sample (2006-2010). These gaps correspond to the vertical distances between actual labour efficiency and that predicted by the estimated constant and the structural indicators (Figure 13). Most countries are within plus or minus 50\% (or approximately $0.5 \mathrm{log}$ points on the chart) of their predicted equilibriums (Figure 14). Most OECD countries, as well as China, India and Indonesia, lie below, while several other non-OECD G20 countries, notably Turkey and Argentina, lie above.

Figure 13. Actual and equilibrium labour efficiency

A. At end of estimation period (2006-2010)

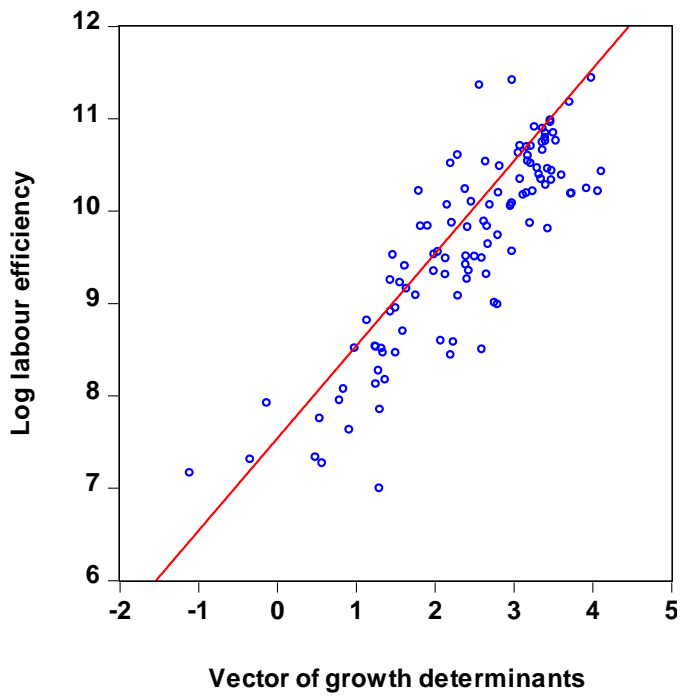

B. At start of long-term projections (2018)

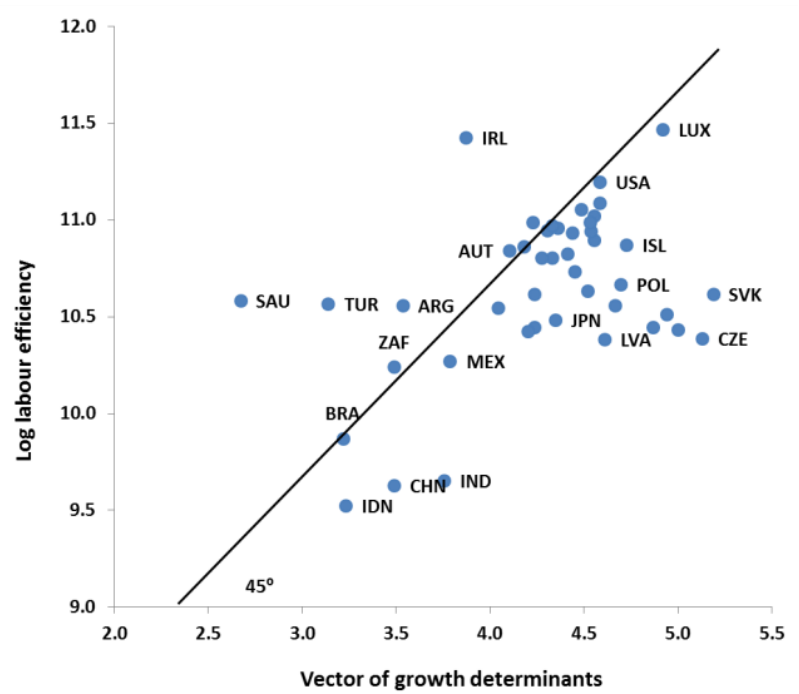

Notes: Panel A shows actual (dots) and equilibrium (line) labour efficiency for the 121 countries in the estimation sample. Panel B shows the same information in the period that initialises the long-term simulations, but only for the countries included in the model. The distance between dots in panel B and the line are the same as in panel A, but values on both the $x$ - and $y$-axes are different for several reasons: First, while Penn World Tables and Economic Outlook measures of labour efficiency are strongly correlated, a fairly systematic level difference exists between the two measures and large discrepancies exist for some individual countries. Second, the last period used in estimation (2006-2010) does not correspond with the starting point of the simulations (2018). Third, additional factors not part of the original estimated equation, namely the domestic and global stocks of R\&D capital, were added post-estimation to the vector of structural indicators. 
Figure 14. Predicted distance to equilibrium labour efficiency in 2018

In log labour efficiency (measured in USD at 2010 PPPs)

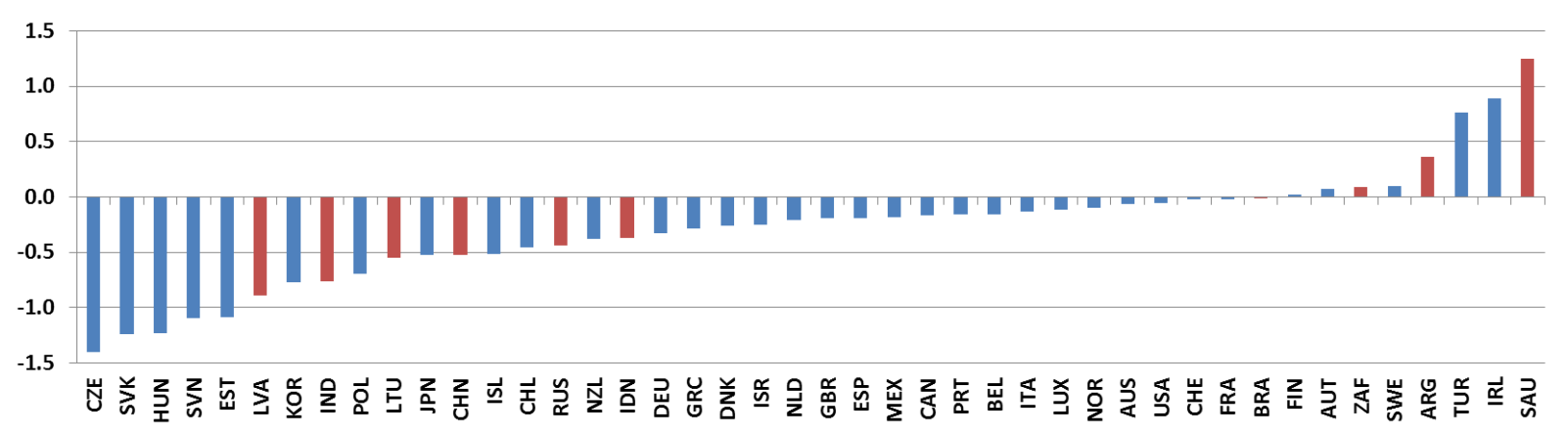

45. The preferred estimated equation's imperfect fit (the $R^{2}$ is only about 0.3 ) means that some part of trend labour efficiency growth rates at the start of the simulations is explainable neither in terms of the assumed global rate of technical progress, nor in terms of catch up to the country-specific equilibrium levels, given observations on the structural indicators and estimated coefficients. In the first period of the long-term projections, these growth residuals have to be dealt with in some way. Setting them to zero would yield very abrupt changes in growth rates in some countries, namely those where the estimated model does not fit well. Instead, gradually eliminating the residuals over several years ensures a smooth path for labour efficiency growth rates. Implicitly, the assumption is that any special factor not captured by the model and influencing trend growth rates taper off to zero over time. ${ }^{15}$ Specifically, $5 \%$ of the previous period's residual is eliminated each period.

46. The equation's less-than-perfect fit also means that it - and more generally the long-term simulation model that it anchors - should primarily be used to illustrate the impact of changes to productivity determinants on outcomes relative to a baseline path. But when it comes to tracing out the baseline itself, for instance the near-term evolution of trend labour efficiency growth rates, results must be interpreted with care, as a large part of this evolution will be driven by the gradual elimination of initial residuals. Naturally, this problem is most serious where the growth residuals are largest, as in the case of rapidly developing countries like China and India. Some of the large residuals for these countries are no doubt attributable not only to weaknesses in the estimation, but also to the difficulty of estimating trend labour efficiency with poor quality data (especially on capital stocks) and to the assumption of fixed factor shares when such shares are changing rapidly. ${ }^{16}$

\subsection{Simulations with no change in explanatory variables}

47. Simulations with no change in explanatory variables show trend labour efficiency growth rates slowly converging to the assumed rate of global technical progress of $1 \%$ (Figure 15). These projections are unrealistic because all of the explanatory variables used in estimation, except (lagged) labour efficiency itself, are assumed to remain constant at their last observed values. Nevertheless, they illustrate the extent

15. This technical solution is not unlike the practice of gradually eliminating estimated fixed effects in the old estimated convergence equation. However, it is conceptually better as residuals are expected to average zero over a long-enough period, unlike fixed effects.

16. For instance, according to Penn World Tables estimates, the labour share in China has declined noticeably since the mid-1990s. Accounting for this trend in the productivity decomposition would yield lower labour efficiency growth rates than using fixed factor shares. Incorporating variable factor shares in the methodology is a potentially interesting avenue but is left to future work as it would need to be done jointly with a revision of the EO's potential output methodology. 
to which large initial residuals can drive much of the short and medium-term evolution of trend labour efficiency growth. In the case of China and India, the elimination of large positive trend labour efficiency growth residuals, together with the convergence process, bring labour efficiency growth rates down into the low single digits. In the case of Japan, trend labour efficiency growth rises noticeably through much of the projection period as large negative initial growth residuals are eliminated. And in the case of Brazil and the United States, which only have small growth residuals at the start of the projection period, and virtually no level disequilibria to eliminate via convergence, trend labour efficiency growth hugs $1 \%$ throughout the projection period.

Figure 15. Trend labour efficiency growth under no-policy-change assumptions

Projections over 2019-60 period (shaded area), selected countries

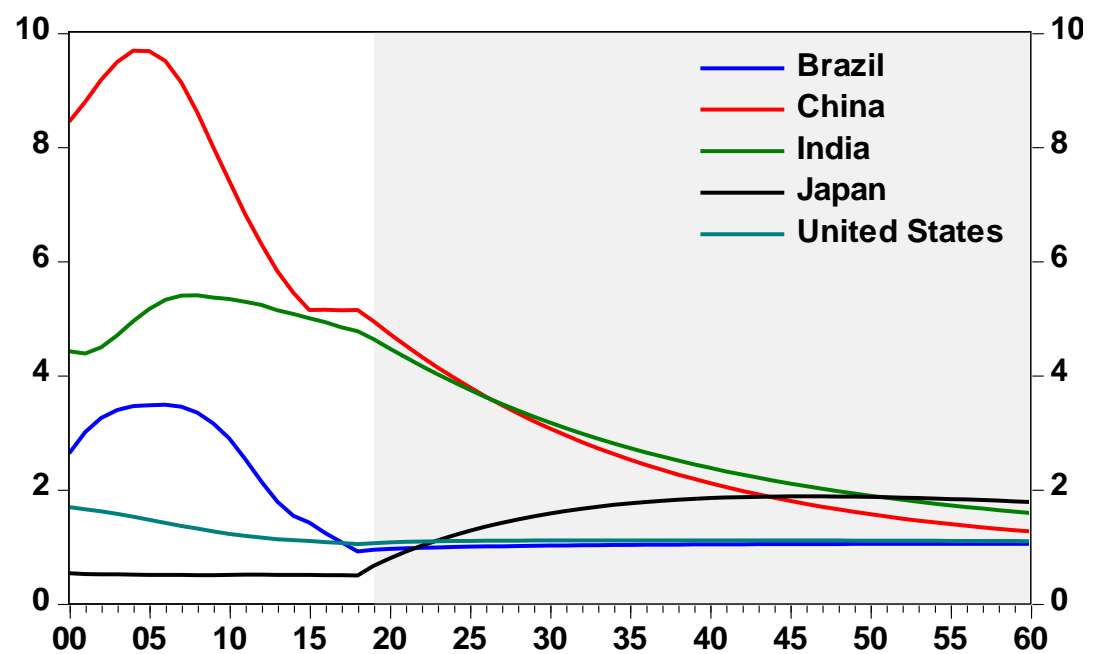

\section{Conclusion}

48. This paper has sought to start from the well-accepted idea of conditional convergence, as well as the best possible empirical starting point in the recent growth literature, to arrive at an equation that could underpin labour efficiency projections in the revised long-term simulation model. After trying a plethora of potential explanatory variables and many different specifications, the preferred equation explains at best a quarter to a third of differences in trend labour efficiency growth rates across a wide range of countries, illustrating that the mechanisms behind productivity gains remain largely a mystery to economists. Furthermore, the equation does not amount to a claim that causation runs only from structural characteristics and policies to growth. It no doubt also runs the other way. In other words, a stronger rule of law, better health and education, well-designed regulations, etc., are normal goods. Richer societies want and tend to buy themselves more of them. The correlations measured above to some extent capture this reverse-causation effect.

49. The explanatory power of the selected structural indicators is much higher when considered from a level perspective, that is, to explain cross-country differences in equilibrium labour efficiency levels. So although the equation developed in this paper is a relatively poor guide to the near-term evolution of trend labour efficiency growth in an unconditional sense, it is more useful to illustrate the likely co-evolution of a country's equilibrium labour efficiency level with its structural characteristics, and to compare scenarios conditional on differences in certain structural conditions and policies, which for the most part will be fed exogenously to the model. While plausible projections for some indicators, like human capital, are available, establishing projections for indicators like rule of law and inflation stability is more difficult. Building plausible and coherent scenarios for the evolution of these 'exogenous' variables will be a necessary part of the next set of long-term scenarios. 


\section{REFERENCES}

Acemoglu, D., S. Johnson and J.A. Robinson (2001), “The Colonial Origins of Comparative Development: An Empirical Investigation”, American Economic Review, No. 91, pp. 1369-1401.

Acemoglu, D., S. Johnson and J.A. Robinson (2002), "Reversal of Fortune: Geography and Institutions in the Making of the Modern World Income Distribution", The Quarterly Journal of Economics, Vol. 117, No. 4 (Nov., 2002), pp. 1231-1294.

Acemoglu, D., S. Johnson and J.A. Robinson (2005), "Institutions as a Fundamental Cause of Long-Run Growth" in P. Aghion and S.N. Durlauf (eds.), Handbook of Economic Growth, Volume 1A, North Holland: Elsevier B.V.

Acemoglu, D. and J.A. Robinson (2012), Why Nations Fail: The Origins of Power, Prosperity, and Poverty, New York: Crown Business.

Andrews, D. and B. Westmore (2014), "Managerial capital and business R\&D as enablers of productivity convergence", OECD Economics Department Working Papers, No. 1137, OECD Publishing, Paris. DOI: http://dx.doi.org/10.1787/5jxx3d441knr-en

Arnold, J., G. Nicoletti and S. Scarpetta (2008), "Regulation, allocative efficiency and productivity in OECD countries: industry and firm-level evidence", OECD Economics Department Working Papers, No. 616, OECD Publishing, Paris. DOI: http://dx.doi.org/10.1787/241447806226

Barro, R. J. and J. W. Lee (2013), "A New Data Set of Educational Attainment in the World, 1950-2010", Journal of Development Economics, 104, September, 184-98.

Barro, R. J. and J. W. Lee (2015), Education Matters - Global Schooling Gains from the 19th to the 21st Century, New York: Oxford University Press.

Barro, R. J. and X. Sala-i-Martin (1992), "Convergence”, Journal of Political Economy, Vol. 100, No. 2, pp. 223-251.

Barro, R. J. (1991), "Economic Growth in a Cross-Section of Countries”, Quarterly Journal of Economics, Vol. 106 (2), pp. 407-43.

Barro, R. J. (1997), “Determinants of Economic Growth: A Cross-Country Empirical Study”, Cambridge, MA: The MIT Press.

Barro, R. J. (2003), "Determinants of Economic Growth in a Panel of Countries”, Annals of Economics and Finance, 4, 231-274.

Barro, R.J. (2015), “Convergence and modernisation”, The Economic Journal, Vol. 125 (June), pp. 911942. 
Bom, P.R.D. and J.E. Ligthart (2014), "What Have We Learned From Three Decades Of Research On The Productivity Of Public Capital?", Journal of Economic Surveys, Vol. 28, No. 5, pp. 889-916.

Bouis, R., R. Duval and F. Murtin (2011), "The policy and institutional drivers of economic growth across OECD and non-OECD economies: new evidence from growth regressions", OECD Economics Department Working Papers, No. 843, OECD Publishing, Paris. DOI: http://dx.doi.org/10.1787/241447806226

Bourlès, R. et al. (2013), "Do product market regulations in upstream sectors curb productivity growth? Panel data evidence for OECD countries", The Review of Economics and Statistics, Vol. 95, No. 5, pp. $1750-1768$.

Brynjolfsson, E. and A. McAfee (2014), The Second Machine Age: Work, Progress, and Prosperity in a Time of Brilliant Technologies, W.W. Norton \& Company.

Burtless, G. (2013), "The impact of population aging and delayed retirement on workforce productivity", Center for Retirement Research at Boston College Working Papers, No. 2013-11.

Cette, G., J. Lopez and J. Mairesse (2013), "Upstream product market regulations, ICT, R\&D and productivity”, NBER Working Papers, No. 19488.

Cette, G., J. Lopez and J. Mairesse (2014), "Product and labour market regulations, production prices, wages and productivity", NBER Working Papers, No. 20563.

Cette, G., R. Lecat and C. Ly-Marin (2016), "Long-term growth and productivity projections in advanced countries", Mimeo.

Cingano, F. (2014), "Trends in income inequality and its impact on economic growth", OECD Social, Employment and Migration Working Papers, No. 163, OECD Publishing, Paris. DOI: http://dx.doi.org/10.1787/618282870448

Conway, P. et al. (2006), "Regulation, competition and productivity convergence", OECD Economics Department Working Papers, No. 509, OECD Publishing, Paris. DOI: http://dx.doi.org/10.1787/431383770805

Dabla-Norris, E. et al. (2015), "Causes and Consequences of Income Inequality: A Global Perspective", IMF Staff Discussion Note, No. 15/13.

de la Fuente, A. and R. Doménech (2000), "Human Capital in Growth Regressions : How Much Difference does Data Quality Makes?", UFAE and IAE Working Papers.

de Rassenfosse, G. and A.B. Jaffe (2017), "Econometric Evidence on the R\&D Depreciation Rate", NBER Working Papers, No. 23072.

Donselaar, P. and C. Koopmans (2016), "The fruits of R\&D: Meta-analyses of the effects of Research and Development on productivity", Research Memorandum 2016-1, Vrije University, Amsterdam.

Égert, B. and P. Gal (2017), "The Quantification of Structural Reforms in OECD Countries: A New Framework", OECD Economics Department Working Papers, No. 1354, OECD Publishing, Paris. DOI: http://dx.doi.org/10.1787/2d887027-en 
Égert, B. (2015), “Aggregate multi-factor productivity: measurement issues in OECD countries”, OECD Economics Department, mimeo.

Égert, B. (2016), "Regulation, Institutions, and Productivity: New Macroeconomic Evidence from OECD Countries", American Economic Review: Papers and Proceedings, Vol. 106, No. 5, pp. 109-113.

Feenstra, R.C., R. Inklaar and M.P. Timmer (2015), "The Next Generation of the Penn World Table", American Economic Review, Vol. 105, No. 10, pp. 3150-82, available for download at www.ggdc.net/pwt

Feyrer, J. (2008), “Aggregate evidence on the link between age structure and productivity", Population and Development Review, Vol. 34 (supp), pp. 78-99.

Feyrer, J. (2007), "Demographics and productivity", The Review of Economics and Statistics, Vol. 89, No. 1, pp. 100-109.

Gordon, R.J. (2016), The Rise and Fall of American Growth: The U.S. Standard of Living since the Civil War, Princeton University Press.

Hall, R. and C. Jones (1999), "Why Do Some Countries Produce so Much More Output per Worker than Others?”, The Quarterly Journal of Economics, No. 114, pp. 83-116.

Hanushek, E.A. and L. Woessmann (2010), "Education and Economic Growth", in D.J. Brewer and P.J. McEwan, Economics of Education, pp. 60-67, Amsterdam: Elsevier.

Hurwicz, L. (1950), "Least-Squares Bias in Time Series", in T.C. Koopman (ed.), Statistical Inference in Dynamic Economic Models, pp. 363-83, New York: Wiley.

Islam, M.R., J.B. Ang and J.B. Madsen (2014), "Quality-Adjusted Human Capital and Productivity Growth”, Economic Inquiry, Vol. 52, No. 2, pp. 757-777.

Johansson, Å. et al. (2013), "Long-term growth scenarios", OECD Economics Department Working Papers, No. 1000, OECD Publishing, Paris. DOI: http://dx.doi.org/10.1787/5k4ddxpr2fmr-en

Jones, C.I. (2015), “The Facts of Economic Growth”, NBER Working Papers, No. 21142.

Kaufmann, D. and A. Kraay (2002), "Growth without Governance", World Bank Policy Research Paper, No. 2928, November.

Kaufmann, D. and A. Kraay (2008), “Governance Indicators: Where are we, where should we be going?", World Bank Research Observer, Spring.

Kaufmann, D., A. Kraay and M. Mastruzzi, (2010), "The Worldwide Governance Indicators”, World Bank Policy Research Working Papers, No. 5430, September.

Koske, I. et al. (2015), "The 2013 update of the OECD's database on product market regulation: Policy insights for OECD and non-OECD countries", OECD Economics Department Working Papers, No. 1200, OECD Publishing, Paris. DOI: http://dx.doi.org/10.1787/5js3f5d3n2vl-en

Langbein, L. and S. Knack (2010), “The Worldwide Governance Indicators; Six, One or None?”, The Journal of Devlopment Studies, Vol. 46, No. 2 (February). 


\section{ECO/WKP(2017)17}

Maestas, N., K.J. Mullen and D. Powell (2016), “The effect of population aging on economic growth, the labour force and productivity", NBER Working Papers, No. 22452.

Mankiw, N.G., D. Romer and D. Weil (1992), "A Contribution to the Empirics of Economic Growth," Quarterly Journal of Economics, Vol. 107, No. 2, pp. 407-438.

Morisson, C. and F. Murtin (2010). "The Kuznets Curve of Education: A Global Perspective on Education Inequalities", Centre for Economics of Education Discussion Papers, No. 116, London School of Economics.

National Research Council of the National Academies (2012), Aging and the Macroeconomy: Long-Term Implications of an Older Population, Washington, D.C.: The National Academies Press.

Nicoletti, G. and S. Scarpetta (2005), "Regulation and economic performance: product market reforms and productivity in the OECD", OECD Economics Department Working Papers, No. 460, OECD Publishing, Paris. DOI: http://dx.doi.org/10.1787/726517007575

OECD (2016), OECD Economic Surveys: Turkey 2016, OECD Publishing, Paris. DOI: http://dx.doi.org/10.1787/eco_surveys-tur-2016-en

Ostry, J.D., A. Berg and C.G. Tsangarides (2014), "Redistribution, Inequality and Growth", IMF Staff Discussion Note, No. 14/02.

Pritchett, L. (2000), “Where has all the Education Gone?”, World Bank Policy Research Papers, No. 1581.

Rodrik, D. (2011), “The Future of Convergence”, HKS Faculty Research Working Paper Series, No. RWP11-033, John F. Kennedy School of Government, Harvard University.

Saia, A., D. Andrews and S. Albrizio (2015), "Productivity spillovers from the global frontier and public policy: industry level evidence", OECD Economics Department Working Papers, No. 1238, OECD Publishing, Paris. DOI: http://dx.doi.org/10.1787/5js03hkvxhmr-en

Turner, D. et al. (2016), "An investigation into improving the real-time reliability of OECD output gap estimates", OECD Economics Department Working Papers, No. 1294, OECD Publishing, Paris. DOI: http://dx.doi.org/10.1787/18151973

Westmore, B. (2013), "R\&D, patenting and growth: the role of public policy", OECD Economics Department Working Papers, No. 1047, OECD Publishing, Paris. DOI: http://dx.doi.org/10.1787/5k46h2rfb4f3-en 
ECO/WKP(2017)17

\section{APPENDIX 1. THE PREVIOUS PRODUCTIVITY CONVERGENCE EQUATIONS}

1. The previous labour efficiency convergence equations were as follows (see Johansson et al. 2013, especially Appendix 7):

$$
\begin{gathered}
\Delta a_{i, t}=\rho_{i, t}\left(a_{i, t}^{*}-a_{i, t-1}\right) \\
a_{i, t}^{*}=\partial_{i}+g_{t}+\beta P M R_{i, t} \\
\rho_{i, t}=h\left(O_{i, t}\right)
\end{gathered}
$$

where $a_{i, t}$ is labour efficiency for country $i$ and year $t ; a^{*}$ is the long-run equilibrium labour efficiency level and $\rho$ is the convergence speed, which in turn is a function $(h)$ of a country's openness at a particular point in time $(O)$. Equilibrium labour efficiency was assumed to depend on the OECD's Product Market Regulation $(P M R)$ indicator. These equations were estimated with both time $\left(g_{t}\right)$ and country $\left(\partial_{i}\right)$ fixed effects using about 350 data points from 40 countries. In this set up, the future evolution of labour efficiency is essentially driven by:

- The exogenous assumption about future technological growth $\left(g_{t}\right)$. This rate was set at $1.3 \%$ per year, probably too high seeing as it is supposed to measure technical progress in the absence of policy and structural improvements.

- Assumptions about the evolution of the PMR indicator. This indicator's estimated effect was very large, probably because it was the only variable explaining the long-run equilibrium labour efficiency level. The paucity of links between structural conditions and long-run productivity (and living standards) is a major weakness of the old framework. So one important objective of the model revision is to build in more effects from structural conditions on productivity.

- The rate at which the estimated fixed country effects are phased out over the projection. The inclusion of country fixed effects in estimation can be useful to pick up the influence of omitted variables. But it is unclear how to treat the estimated fixed effects in the context of a long-term projection. In practice, these effects are large, especially for poor countries, and how they are handled over the projection horizon has a big influence on the results. However, any such handling is necessarily ad hoc. Moreover, the relevant literature has found that including country fixed effects generates a large upward bias in the estimated speed of convergence. ${ }^{17}$ Therefore, the revised model is based on a long-run convergence equation that eschews country fixed effects. This requires incorporating more determinants of long-run convergence in productivity levels into the estimation.

- Openness and its projected evolution, which affects the speed of convergence. In the previous model, a separate equation was estimated to relate openness to its determinants, including living standards, the (trade-weighted) living standards of trade partners, population, trade regulation and the real effective exchange rate. Despite some of these variables being endogenously determined in the long-term model, they did not feed into the openness measure. Openness had been projected once, when the model was designed, and those projections entered the model exogenously.

17. This is referred to in the literature as the Hurwicz-type bias (Hurwicz, 1950), see also Barro (2015). 
APPENDIX 2. DESCRIPTIVE STATISTICS FOR THE EXPLANATORY VARIABLES

Table A2.1 Descriptive statistics for the variables used in estimation

\begin{tabular}{|c|c|c|c|c|c|c|c|c|c|}
\hline \multirow{2}{*}{ Variable description } & \multirow{2}{*}{ Source } & \multicolumn{5}{|c|}{ All sample, 1961-2010 } & \multicolumn{3}{|c|}{ Cross-section, last period } \\
\hline & & Obs. & Mean & Std. Dev. & Min & Max & Obs. & Mean & Std. Dev. \\
\hline Real GDP per capita (in USD at 2010 PPPs) & PWT v8.1 & 1093 & 14552 & 21910 & 257 & 295032 & 121 & 20397 & 24938 \\
\hline $\begin{array}{l}\text { Labour productiviy (real GDP per worker in USD } \\
\text { at } 2010 \text { PPP) }\end{array}$ & PWT v8.1 & 1043 & 37010 & 57266 & 661 & 1047962 & 121 & 43923 & 43407 \\
\hline Labour efficiency (in USD at 2010 PPP) & PWT v8.1 & 1043 & 25795 & 76363 & 332 & 1719656 & 121 & 26601 & 28749 \\
\hline Government consumption ratio & PWT v8.1 & 1044 & 0.19 & 0.09 & 0.01 & 0.63 & 128 & 0.18 & 0.07 \\
\hline $\begin{array}{l}\text { Terms-of-trade change (growth rate over five } \\
\text { years of export prices relative to import prices) }\end{array}$ & IMF and WDI & 1044 & 1.04 & 0.42 & 0.14 & 7.87 & 128 & 1.07 & 0.17 \\
\hline Employment ratio & PWT v8.1 & 1356 & 0.39 & 0.09 & 0.13 & 0.74 & 121 & 0.43 & 0.09 \\
\hline Inflation rate & PWT v8.1 & 1044 & 0.48 & 4.41 & -0.04 & 117.50 & 128 & 0.05 & 0.10 \\
\hline Investment ratio (to GDP, private and public) & PWT v8.1 & 1491 & 0.20 & 0.10 & -0.10 & 0.74 & 121 & 0.21 & 0.07 \\
\hline Openness (exports plus imports) (\% of GDP) & PWT v8.1 & 1764 & 74.85 & 48.96 & 1.08 & 432.95 & 118 & 91.59 & 59.23 \\
\hline Average years of school attainment for females & Barro and Lee & 1044 & 6.18 & 3.24 & 0.09 & 13.23 & 128 & 8.23 & 3.06 \\
\hline Average years of school attainment for males & Barro and Lee & 1044 & 6.98 & 2.85 & 0.46 & 13.36 & 128 & 8.72 & 2.67 \\
\hline $\begin{array}{l}\text { Average years of school attainment for males and } \\
\text { females }\end{array}$ & Barro and Lee & 1044 & 6.57 & 3.02 & 0.29 & 13.18 & 121 & 8.56 & 2.82 \\
\hline Life expectancy at birth & WDI & 1044 & 65.97 & 10.55 & 31.24 & 82.98 & 121 & 70.28 & 10.05 \\
\hline Fertility rate & WDI & 1043 & 3.67 & 1.93 & 0.97 & 8.67 & 128 & 2.77 & 1.42 \\
\hline Human capital index & See Appendix 4 & 1099 & 2.05 & 0.63 & 1.03 & 3.65 & 121 & 2.53 & 0.62 \\
\hline Population-adjusted openness & See Appendix 2 & 1099 & 0.01 & 0.44 & -0.73 & 3.26 & 121 & 0.23 & 0.53 \\
\hline Democraty, converted from 1 to 7 & EFW & 862 & 4.65 & 2.15 & 1.00 & 7.00 & 127 & 4.83 & 2.09 \\
\hline Rule of Law & WGI & 385 & 0.06 & 1.00 & -2.11 & 1.98 & 121 & 0.14 & 0.99 \\
\hline Product Market Regulation & See Appendix 3 & 1099 & 2.90 & 0.71 & 1.10 & 4.61 & 121 & 2.39 & 0.66 \\
\hline Index of low and stable inflation & WDI & 929 & 8.03 & 2.16 & 0.00 & 9.93 & 121 & 9.02 & 0.74 \\
\hline R\&D expenditures (\% of GDP) & WDI & 260 & 0.92 & 0.92 & 0.01 & 4.23 & 96 & 0.94 & 0.96 \\
\hline $\begin{array}{l}\text { Patent applications (residents and non-residents) } \\
\text { per } 1000 \text { population }\end{array}$ & WDI & 838 & 327 & 673.38 & 0.15 & 7241.97 & 97 & 286.70 & 587.48 \\
\hline
\end{tabular}

Sources and notes: PWT v8.1 refers to the Penn World Tables version 8.1 (see Feenstra et al., 2015); IMF refers to the International Monetary Fund's International Financial Statistics database and/or World Economic Outlook database; WDI refers to the World Bank's World Development Indicators database; Barro and Lee refers to the Educational Attainment Dataset by Robert Barro and Jong-Wha Lee (see Barro and Lee, 2013 and www.barrolee.com); WGI refers to the World Bank's Worldwide Governance Indicators database. These statistics are shown to facilitate interpretation of the coefficient estimates in the estimated models. However, the samples used in this table do not always correspond exactly to those used in Tables 1 to 3. 
Table A2.2 Correlation coefficients for dependent variables and regressors

\begin{tabular}{|c|c|c|c|c|c|c|c|c|c|c|c|c|c|c|c|c|c|}
\hline & $\begin{array}{l}\text { GDP per } \\
\text { capita } \\
\text { growth }\end{array}$ & $\begin{array}{l}\text { GDP per } \\
\text { worker } \\
\text { growth }\end{array}$ & $\begin{array}{l}\text { Labour } \\
\text { efficiency } \\
\text { growth }\end{array}$ & $\begin{array}{l}\text { Log GDP } \\
\text { per capita }\end{array}$ & $\begin{array}{l}\text { Log GDP } \\
\text { per } \\
\text { worker }\end{array}$ & $\begin{array}{c}\log \\
\text { labour } \\
\text { efficiency }\end{array}$ & $\begin{array}{c}\text { Life } \\
\text { expectancy }\end{array}$ & $\begin{array}{l}\text { Employment } \\
\text { ratio }\end{array}$ & $\begin{array}{l}\text { th Investment } \\
\text { ratio }\end{array}$ & $\begin{array}{c}\text { Rule of } \\
\text { law }\end{array}$ & $\begin{array}{l}\text { Population- } \\
\text { adjusted } \\
\text { openness }\end{array}$ & $\begin{array}{l}\text { Human } \\
\text { capital }\end{array}$ & $\begin{array}{c}\text { Low and } \\
\text { stable } \\
\text { inflation }\end{array}$ & $\begin{array}{l}\text { Product } \\
\text { market } \\
\text { regulation }\end{array}$ & $\begin{array}{c}\text { R\&D } \\
\text { expenditure, } \\
\% \text { of GDP }\end{array}$ & $\begin{array}{c}\text { Patent } \\
\text { applications } \\
\text { per } 1000 \text { pop }\end{array}$ & $\begin{array}{c}\text { Income } \\
\text { inequality } \\
\text { (GINI } \\
\text { index) }\end{array}$ \\
\hline GDP per capita growth & 1.000 & & & & & & & & & & & & & & & & \\
\hline GDP per worker growth & 0.896 & 1.000 & & & & & & & & & & & & & & & \\
\hline Labour efficiency growth & 0.885 & 0.951 & 1.000 & & & & & & & & & & & & & & \\
\hline Log GDP per capita & 0.106 & 0.054 & -0.030 & 1.000 & & & & & & & & & & & & & \\
\hline Log GDP per worker & 0.091 & 0.051 & -0.035 & 0.984 & 1.000 & & & & & & & & & & & & \\
\hline Log labour efficiency & 0.110 & 0.066 & -0.026 & 0.967 & 0.985 & 1.000 & & & & & & & & & & & \\
\hline Life expectancy & 0.216 & 0.154 & 0.076 & 0.829 & 0.815 & 0.784 & 1.000 & & & & & & & & & & \\
\hline Employment ratio & 0.092 & 0.065 & 0.035 & 0.364 & 0.195 & 0.174 & 0.298 & & & & & & & & & & \\
\hline Investment ratio & 0.320 & 0.251 & 0.114 & 0.584 & 0.560 & 0.511 & 0.536 & 0.302 & 1.000 & & & & & & & & \\
\hline Rule of law & 0.181 & 0.156 & 0.074 & 0.756 & 0.709 & 0.698 & 0.687 & 0.457 & 0.563 & 1.000 & & & & & & & \\
\hline Population-adjusted openness & 0.214 & 0.149 & 0.118 & 0.286 & 0.263 & 0.251 & 0.274 & 0.206 & 0.324 & 0.184 & 1.000 & & & & & & \\
\hline Human capital & 0.149 & 0.122 & 0.091 & 0.721 & 0.677 & 0.648 & 0.758 & 0.424 & 0.362 & 0.623 & 0.239 & 1.000 & & & & & \\
\hline Low and stable inflation & 0.230 & 0.178 & 0.137 & 0.316 & 0.293 & 0.311 & 0.292 & 0.212 & 0.288 & 0.335 & 0.259 & 0.252 & 1.000 & & & & \\
\hline Product market regulation & -0.204 & -0.172 & -0.108 & -0.739 & -0.686 & -0.663 & -0.711 & -0.475 & -0.496 & -0.772 & -0.332 & -0.723 & -0.367 & 1.000 & & & \\
\hline R\&D expenditure, $\%$ of $G$ & -0.185 & -0.126 & -0.131 & 0.606 & 0.556 & 0.534 & 0.518 & 0.501 & 0.330 & 0.709 & 0.027 & 0.568 & 0.330 & -0.546 & 1.000 & & \\
\hline Patent applications per 1000 pop & 0.028 & 0.040 & 0.011 & 0.446 & 0.398 & 0.388 & & & & 0.515 & & & & -0.371 & 0.583 & 1.000 & \\
\hline Income inequality (GINI index) & -0.151 & -0.247 & -0.194 & -0.257 & -0.229 & -0.213 & -0.293 & -0.240 & -0.207 & -0.377 & -0.191 & -0.339 & -0.244 & 0.277 & -0.412 & -0.256 & 1.000 \\
\hline
\end{tabular}

Note: The sample used is the same as in column 2 of Table 3, with pairwise deletion when one of the variables has a smaller sample than the other.

Figure A2.1 GDP per capita, labour productivity and labour efficiency

Average log values for the last period used in estimation (2006-10)
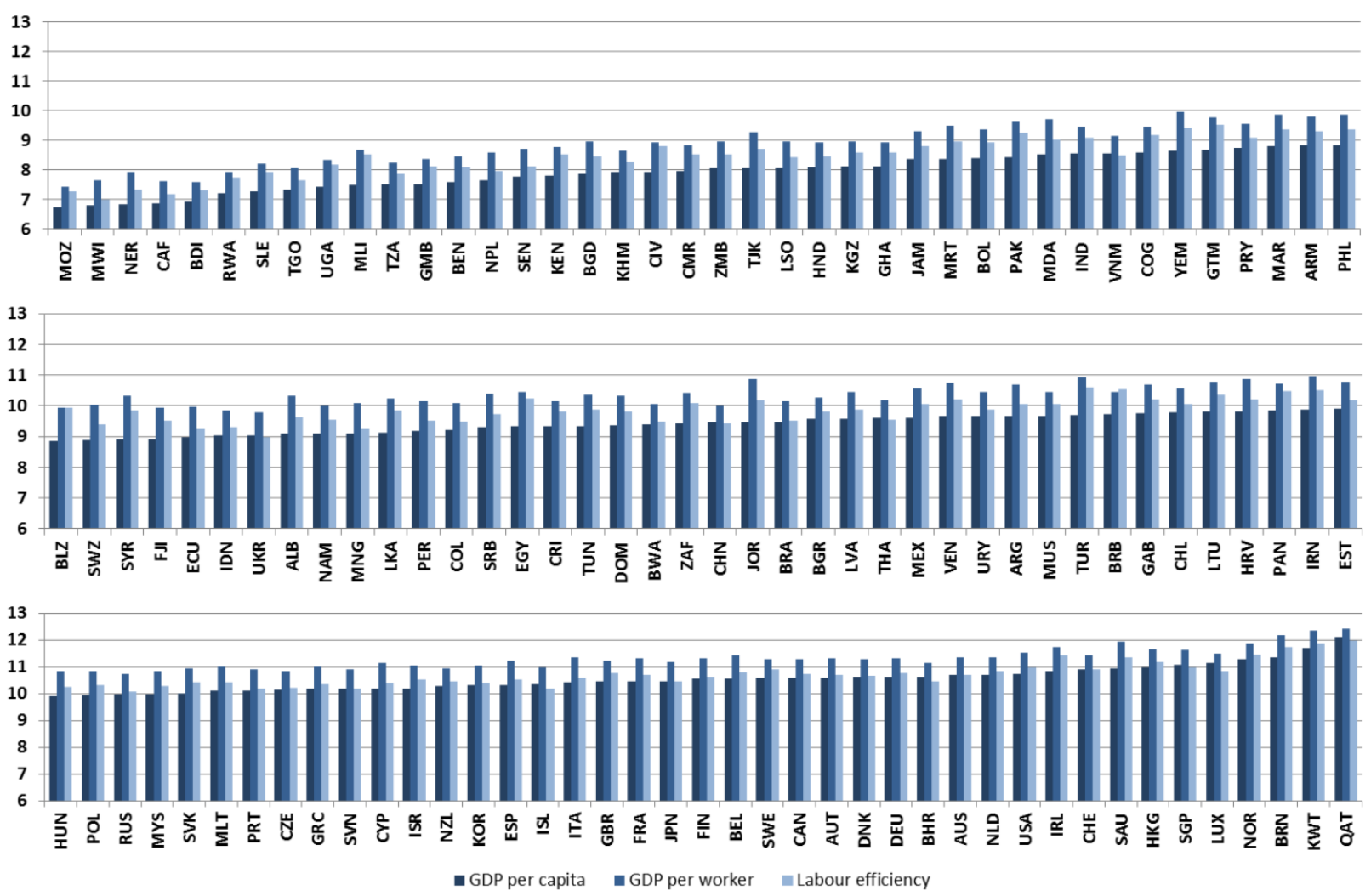

1. The information in the documents with reference to "Cyprus" relates to the southern part of the Island. There is no single authority representing both Turkish and Greek Cypriot people on the Island. Turkey recognizes the Turkish Republic of Northern Cyprus (TRNC). Until a lasting and equitable solution is found within the context of the United Nations, Turkey shall preserve its position concerning the "Cyprus issue".

2. The Republic of Cyprus is recognised by all members of the United Nations with the exception of Turkey. The information in the documents relates to the area under the effective control of the Government of the Republic of Cyprus.

Source: Penn World Tables v8.1. Labour efficiency is obtained by decomposition using a Cobb-Douglas production function with a fixed wage share of two-thirds, following Economic Outlook methodology. 
Figure A2.2 Life expectancy at birth

Expected years of life, average for the last period used in estimation (2006-10)
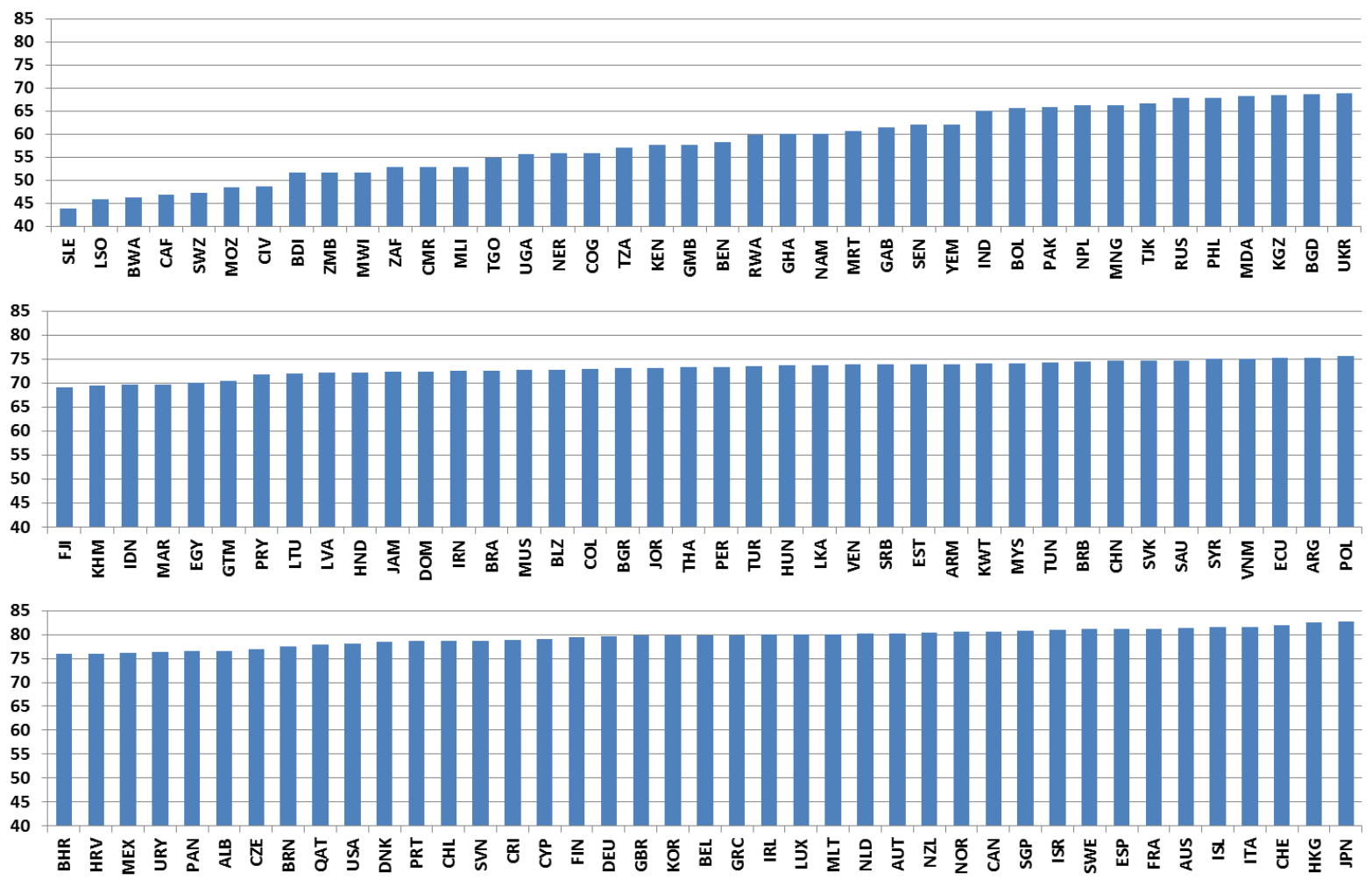

1. The information in the documents with reference to "Cyprus" relates to the southern part of the Island. There is no single authority representing both Turkish and Greek Cypriot people on the Island. Turkey recognizes the Turkish Republic of Northern Cyprus (TRNC). Until a lasting and equitable solution is found within the context of the United Nations, Turkey shall preserve its position concerning the "Cyprus issue".

2. The Republic of Cyprus is recognised by all members of the United Nations with the exception of Turkey. The information in the documents relates to the area under the effective control of the Government of the Republic of Cyprus.

Source: World Bank Worldwide Development Indicators database. 


\section{Figure A2.3 Rule of law}

Average index for the last period used in estimation (2006-10), higher is better
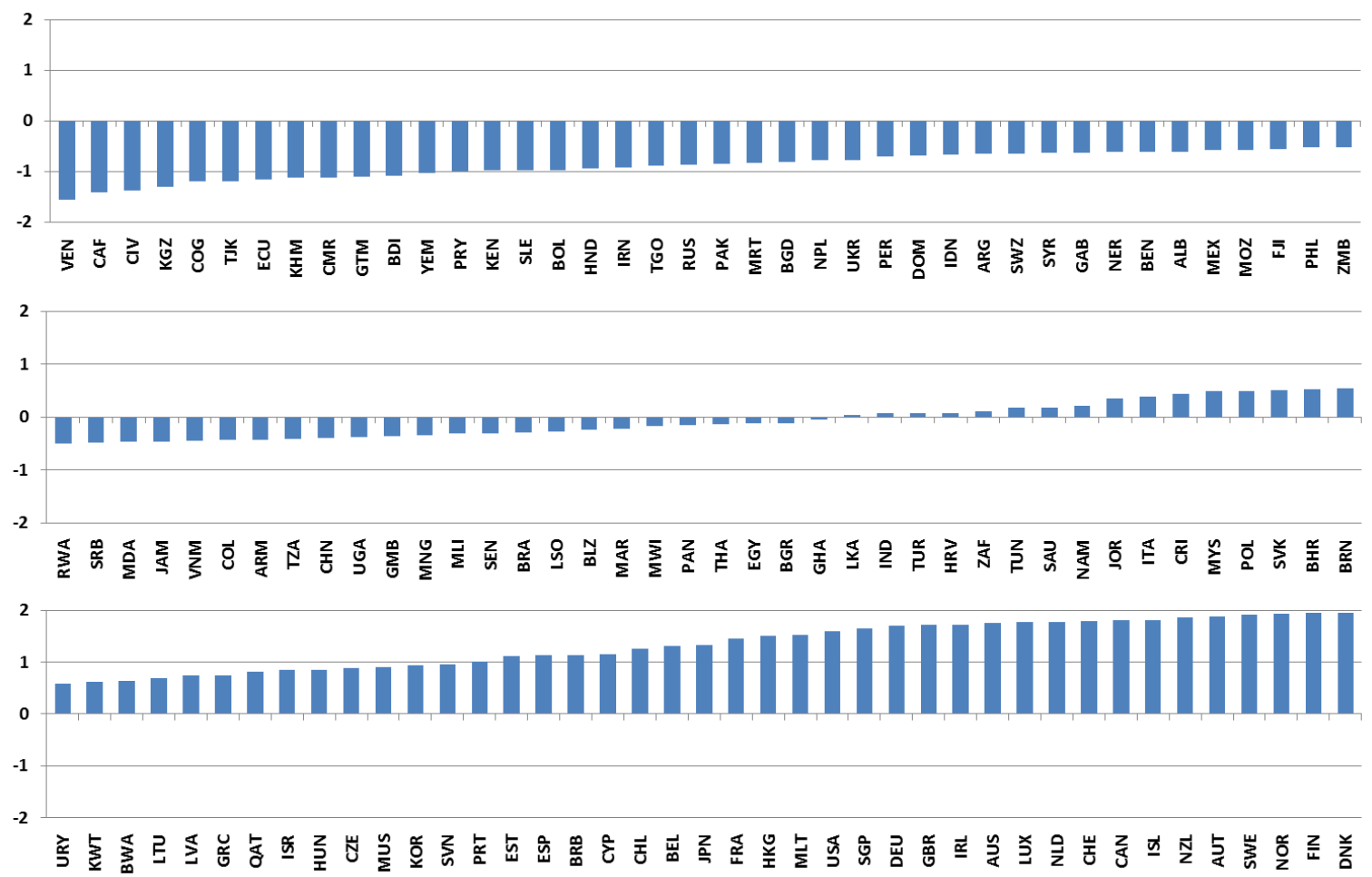

1. The information in the documents with reference to "Cyprus" relates to the southern part of the Island. There is no single authority representing both Turkish and Greek Cypriot people on the Island. Turkey recognizes the Turkish Republic of Northern Cyprus (TRNC). Until a lasting and equitable solution is found within the context of the United Nations, Turkey shall preserve its position concerning the "Cyprus issue".

2. The Republic of Cyprus is recognised by all members of the United Nations with the exception of Turkey. The information in the documents relates to the area under the effective control of the Government of the Republic of Cyprus.

Source: World Bank Worldwide Governance Indicators database. 


\section{Figure A2.4 Low and stable inflation}

Average index for the last period used in estimation (2006-10), higher is better
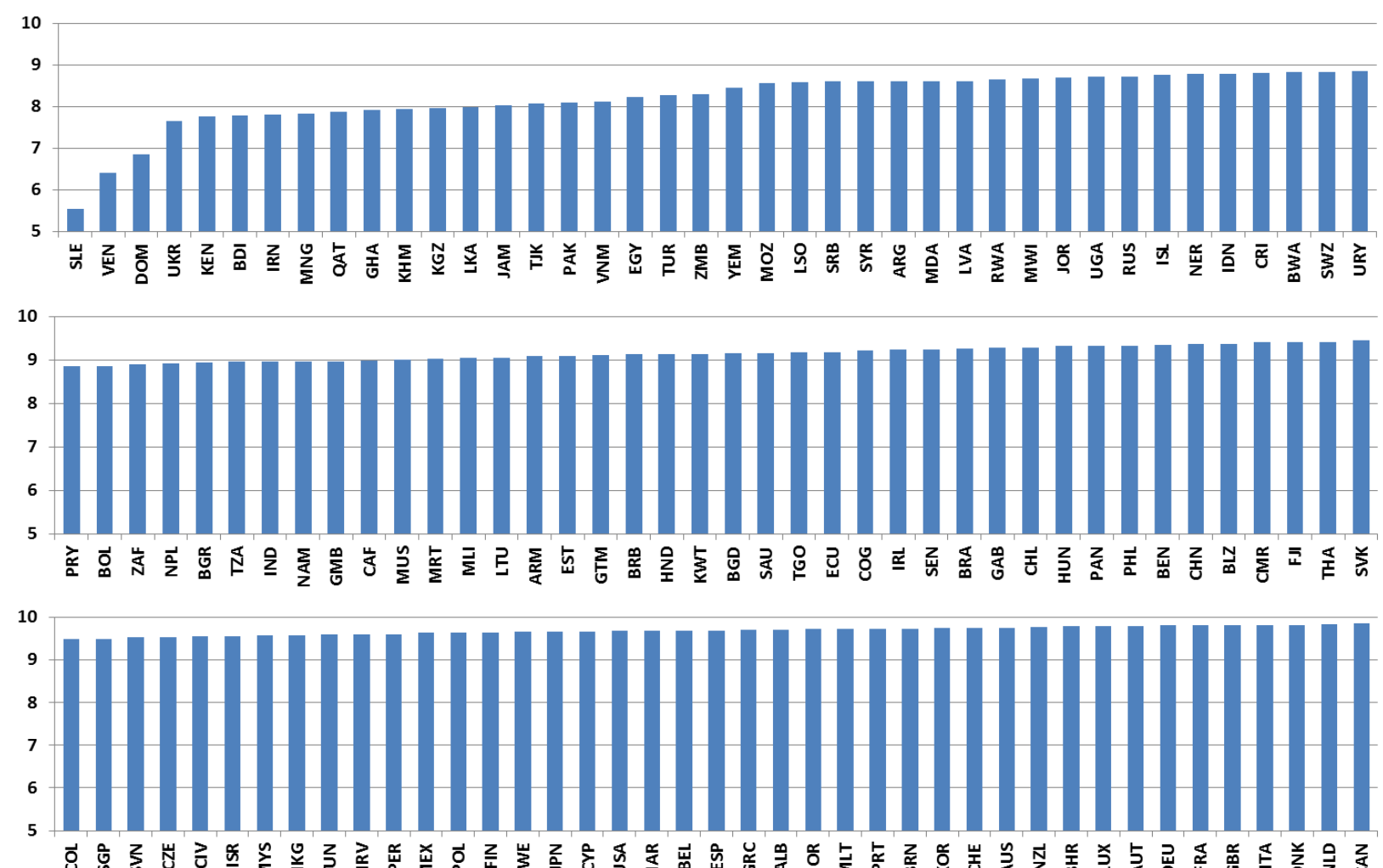

1. The information in the documents with reference to "Cyprus" relates to the southern part of the Island. There is no single authority representing both Turkish and Greek Cypriot people on the Island. Turkey recognizes the Turkish Republic of Northern Cyprus (TRNC). Until a lasting and equitable solution is found within the context of the United Nations, Turkey shall preserve its position concerning the "Cyprus issue".

2. The Republic of Cyprus is recognised by all members of the United Nations with the exception of Turkey. The information in the documents relates to the area under the effective control of the Government of the Republic of Cyprus.

Source: World Bank Worldwide Development Indicators database. 
Figure A2.5 Innovation based on R\&D expenditures

R\&D expenditures as \% of GDP in last period used in estimation (2006-10)
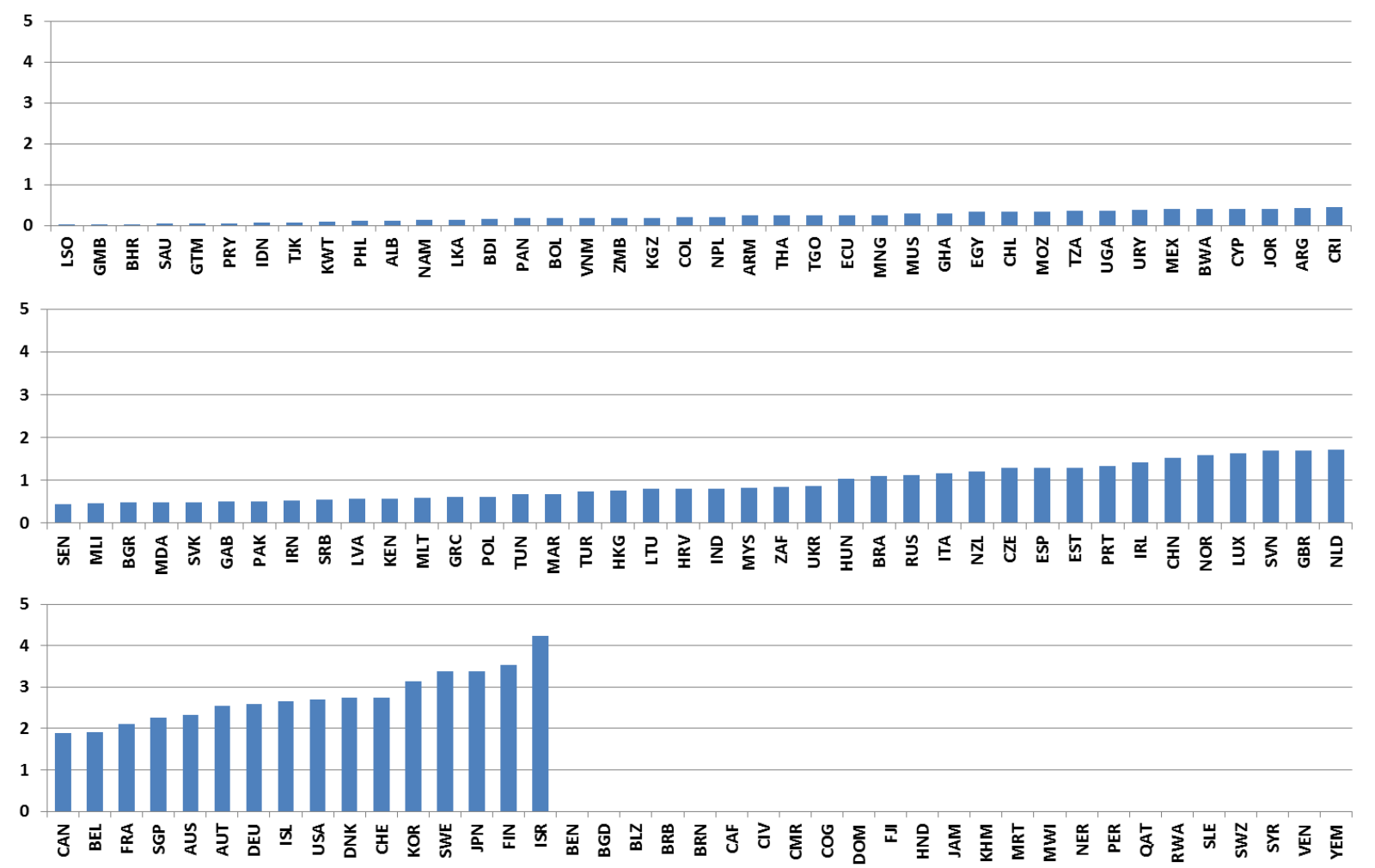

1. The information in the documents with reference to "Cyprus" relates to the southern part of the Island. There is no single authority representing both Turkish and Greek Cypriot people on the Island. Turkey recognizes the Turkish Republic of Northern Cyprus (TRNC). Until a lasting and equitable solution is found within the context of the United Nations, Turkey shall preserve its position concerning the "Cyprus issue".

2. The Republic of Cyprus is recognised by all members of the United Nations with the exception of Turkey. The information in the documents relates to the area under the effective control of the Government of the Republic of Cyprus.

Source: World Bank Worldwide Governance Indicators database. 
Figure A2.6 Innovation based on patent applications

Total patent applications by residents and non-residents per thousand population in the last period used in estimation (2006-10), log scale
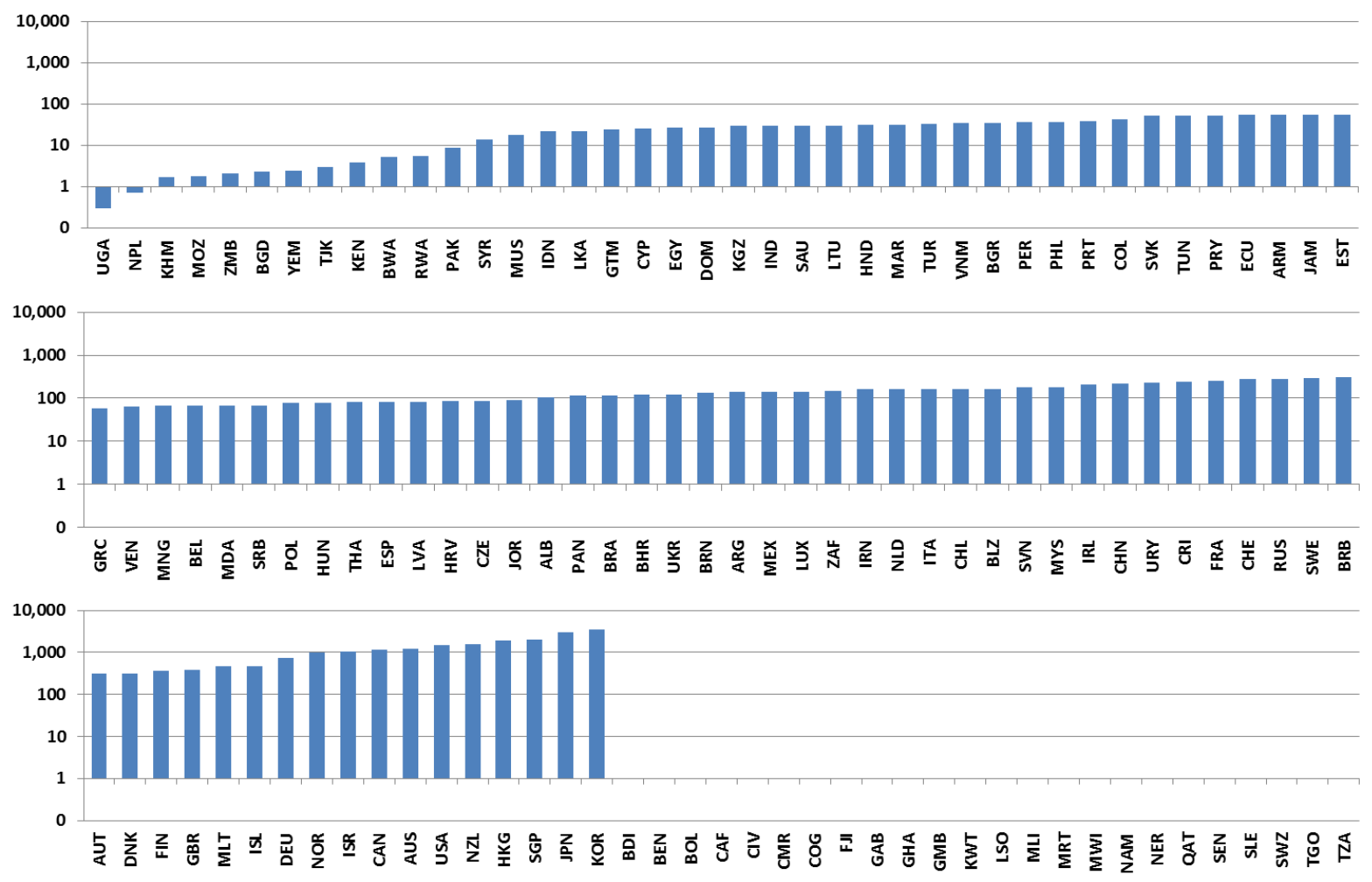

1. The information in the documents with reference to "Cyprus" relates to the southern part of the Island. There is no single authority representing both Turkish and Greek Cypriot people on the Island. Turkey recognizes the Turkish Republic of Northern Cyprus (TRNC). Until a lasting and equitable solution is found within the context of the United Nations, Turkey shall preserve its position concerning the "Cyprus issue".

2. The Republic of Cyprus is recognised by all members of the United Nations with the exception of Turkey. The information in the documents relates to the area under the effective control of the Government of the Republic of Cyprus.

Source: World Bank Worldwide Governance Indicators database, Penn World Tables v8.1. 
Figure A2.7 Measure of income inequality

GINI index used in the last estimation period (2006-10), higher index means greater income inequality
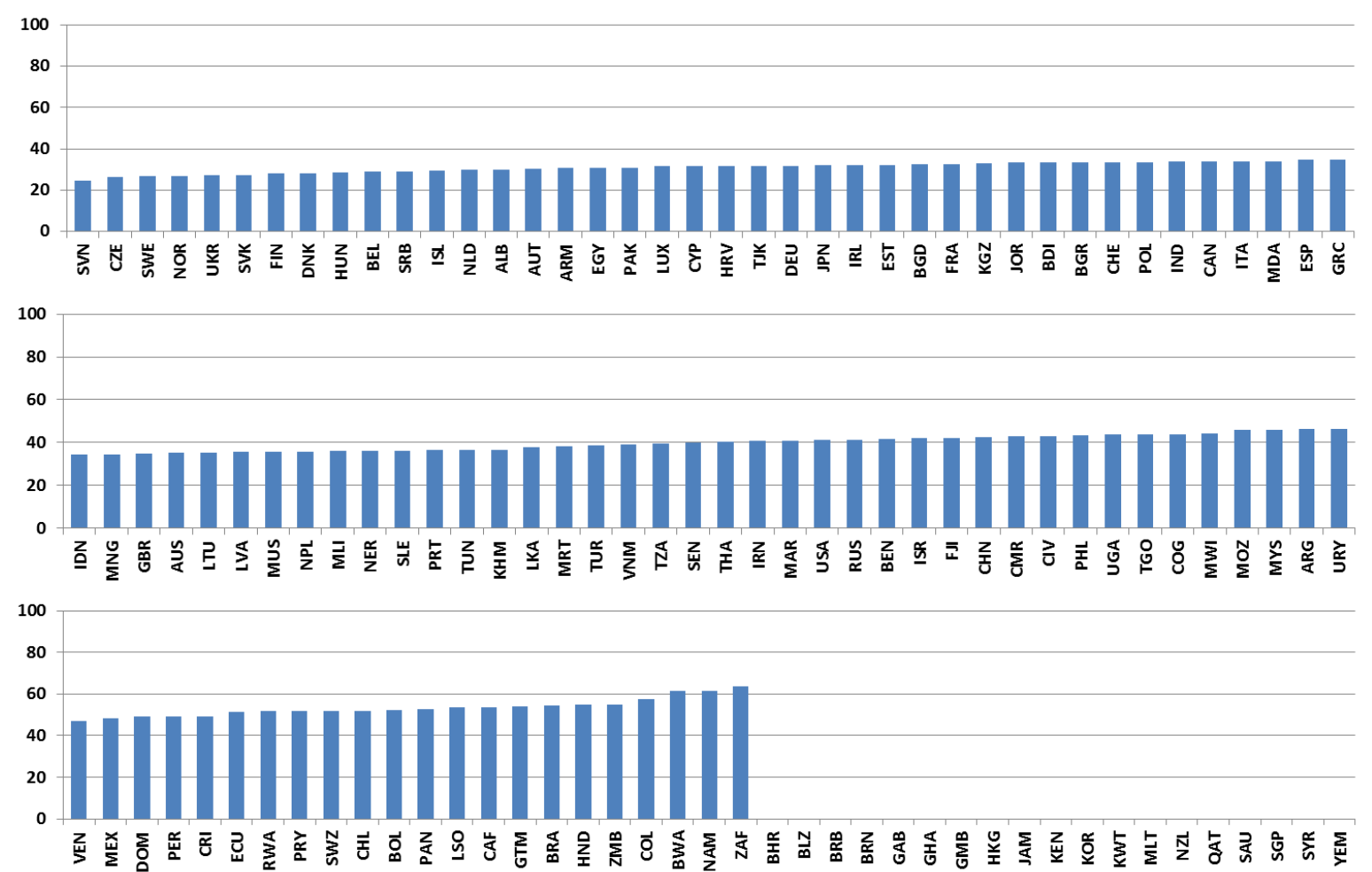

1. The information in the documents with reference to "Cyprus" relates to the southern part of the Island. There is no single authority representing both Turkish and Greek Cypriot people on the Island. Turkey recognizes the Turkish Republic of Northern Cyprus (TRNC). Until a lasting and equitable solution is found within the context of the United Nations, Turkey shall preserve its position concerning the "Cyprus issue".

2. The Republic of Cyprus is recognised by all members of the United Nations with the exception of Turkey. The information in the documents relates to the area under the effective control of the Government of the Republic of Cyprus.

Source: World Bank's World Development Indicators (WDI). 


\section{APPENDIX 3. CONSTRUCTING A POPULATION-ADJUSTED OPENNESS MEASURE}

1. The population-adjusted openness measure is obtained as the difference between the standard openness measure (the sum of exports and imports as a percentage of GDP) and the openness predicted by country size, as measured by population. This adjustment is made to reflect the reality that large countries tend to be less dependent on foreign trade than smaller ones. Trade and GDP data are from the World Bank's World Development Indicators database and population is from the Penn World Tables v8.1.

2. First, the standard openness measure for country $i$ and year $t\left(\right.$ Open $\left._{i, t}\right)$ is regressed on the logarithm of population $\left(P O P_{i, t}\right)$ using the following specification:

$$
\text { Open }_{i, t}=\alpha_{0}+\alpha_{1} \log \left(P O P_{i, t}\right)+\varepsilon_{i, t},
$$

The results indicate that each $1 \%$ increase in population size is associated with a 0.14 percentage points fall in openness $(p$-value $<0.01)$. The residuals from this regression measure the difference between the standard openness measure and 'predicted openness' based on population. These residuals enter the regressions presented in the main text as 'population-adjusted openness'. This measure is above zero for countries that are more open to trade than their size would predict, and below zero for countries that are less open to trade than their size predicts (Figure A3.1). 


\section{Figure A3.1 Population-adjusted openness}

Average index for the last period used in estimation (2006-10). A higher value means that a country is more opened than predicted by its population size
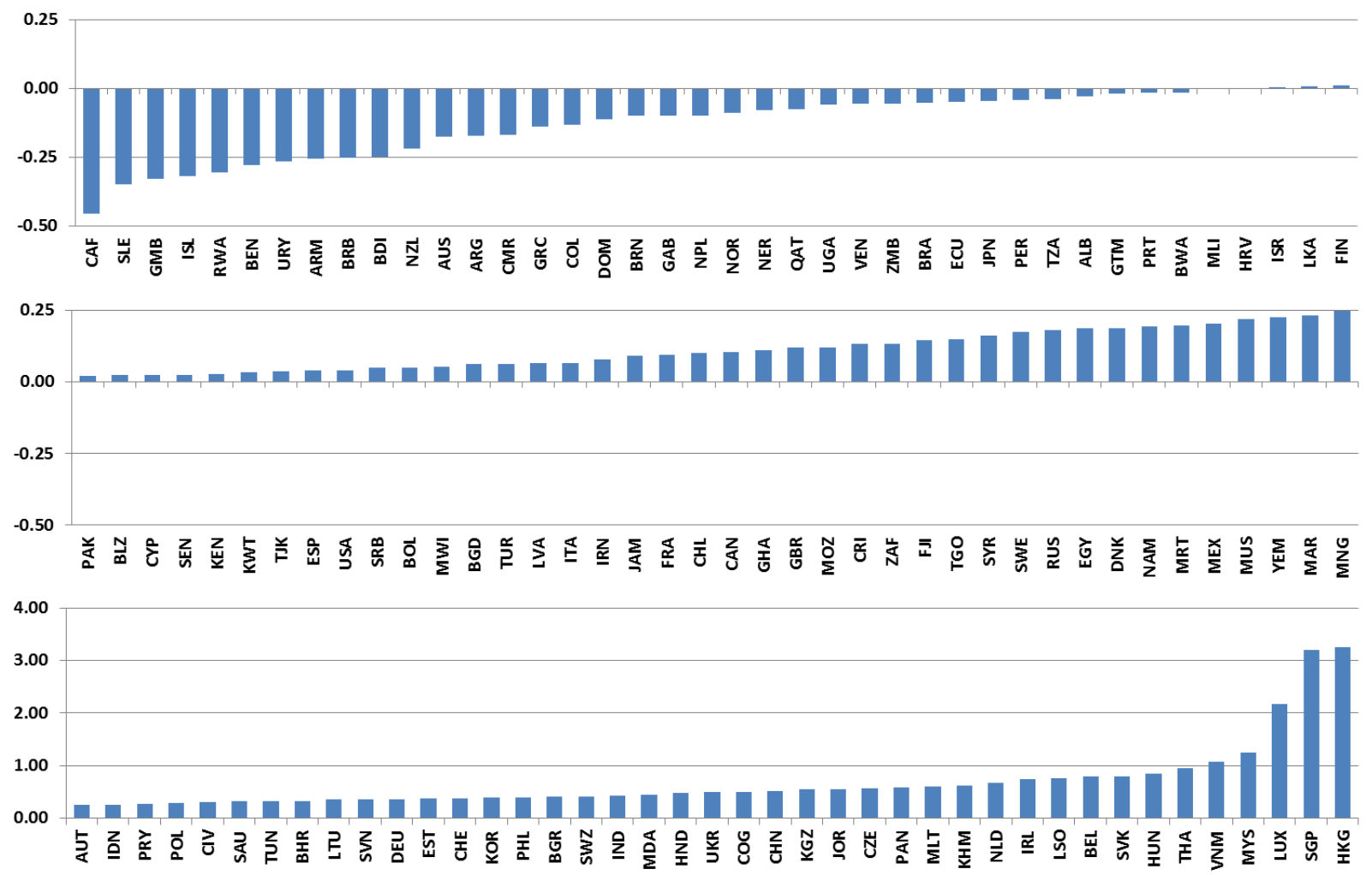

1. The information in the documents with reference to "Cyprus" relates to the southern part of the Island. There is no single authority representing both Turkish and Greek Cypriot people on the Island. Turkey recognizes the Turkish Republic of Northern Cyprus (TRNC). Until a lasting and equitable solution is found within the context of the United Nations, Turkey shall preserve its position concerning the "Cyprus issue".

2. The Republic of Cyprus is recognised by all members of the United Nations with the exception of Turkey. The information in the documents relates to the area under the effective control of the Government of the Republic of Cyprus.

Source: Penn World Tables v8.1. 


\section{APPENDIX 4. CONSTRUCTING PRODUCT MARKET REGULATION MEASURES}

1. Product market regulation (PMR) indices are available in the OECD PMR database only for selected years and countries: 28 OECD countries in the original 1998 vintage, an extra two OECD countries in 2003, all 34 OECD countries and five non-OECD countries in 2008 and an additional 26 nonOECD countries in the latest vintage referring to 2013. For use in the regressions, these official PMR measures are interpolated and backcasted. Moreover, proxy PMR measures are created for non-OECD countries that do not have any official PMR estimates. It is important to note that official PMR measures are always kept when available (i.e. they are not replaced by proxy measures).

\section{Countries with official PMR measures}

2. For countries with two or more official PMR measures, predicted PMR values for years that fall between official estimates are obtained by linear interpolation. Next, the earliest official measure is backcasted using the following equation relating PMR for country $i$ and year $t$ to the World Bank's Worldwide Governance Indicator for regulatory quality $\left(R E G Q_{i, t}\right)$ :

$$
P M R_{i, t}=\beta_{0}+\beta_{1} R E G Q_{i, t}+\varphi_{\mathrm{t}}+\varepsilon_{i, t}
$$

where $\varphi_{\mathrm{t}}$ is a year fixed effect (Table A4.1). As expected, better regulatory quality (higher value) is associated with a better PMR index (lower value). For backcasting, this equation is applied in first difference, including time fixed effects scaled to yearly changes. Applying the equation in first difference avoids any sudden jumps in the composite series. This procedure extends official PMR indices to 1996 at the most, the earliest year for which the regulatory quality index is available.

Table A4.1 Estimated equations to construct PMR proxies

Dependent variable is $P M R_{i, t}$

\begin{tabular}{|c|c|}
\hline Constant & $\begin{array}{l}2.598^{* * *} \\
(0.0572)\end{array}$ \\
\hline Regulatory quality & $\begin{array}{c}-0.708^{* * *} \\
(0.0428)\end{array}$ \\
\hline Countries & 65 \\
\hline Time period & $\begin{array}{l}1998,2003 \\
2008,2013\end{array}$ \\
\hline Period fixed effects & Yes \\
\hline Country fixed effects & No \\
\hline R-squared & $77.2 \%$ \\
\hline Observations & 161 \\
\hline
\end{tabular}

Notes: Equation estimated using panel least squares. Reported (White) standard errors are robust to arbitrary heteroskedasticity and within-country serial correlation. Asterisks $\left.{ }^{* * \star}\right)$ indicate that coefficients are statistically significant at the $1 \%$ level. 


\section{Countries without official PMR measures}

3. For countries (all non-OECD) that do not have any official PMR measure, PMR proxies are obtained based on the regulatory quality index by applying the above equation in levels. A comparison of official versus predicted PMRs for countries and years with both an official PMR and a regulatory quality measure yields a tight-enough relationship to rely on the equation when no PMR exists (Figure A4.1). Applying the equation in levels yields proxy PMRs for years 1998, 2003, 2008 and 2013 when the regulatory quality measure is available. Intervening years are then obtained by linear interpolation.

Figure A4.1 Official versus predicted PMR

Predictions based on the equation in Table A4.1. The dots represent mostly OECD but also some non-OECD countries

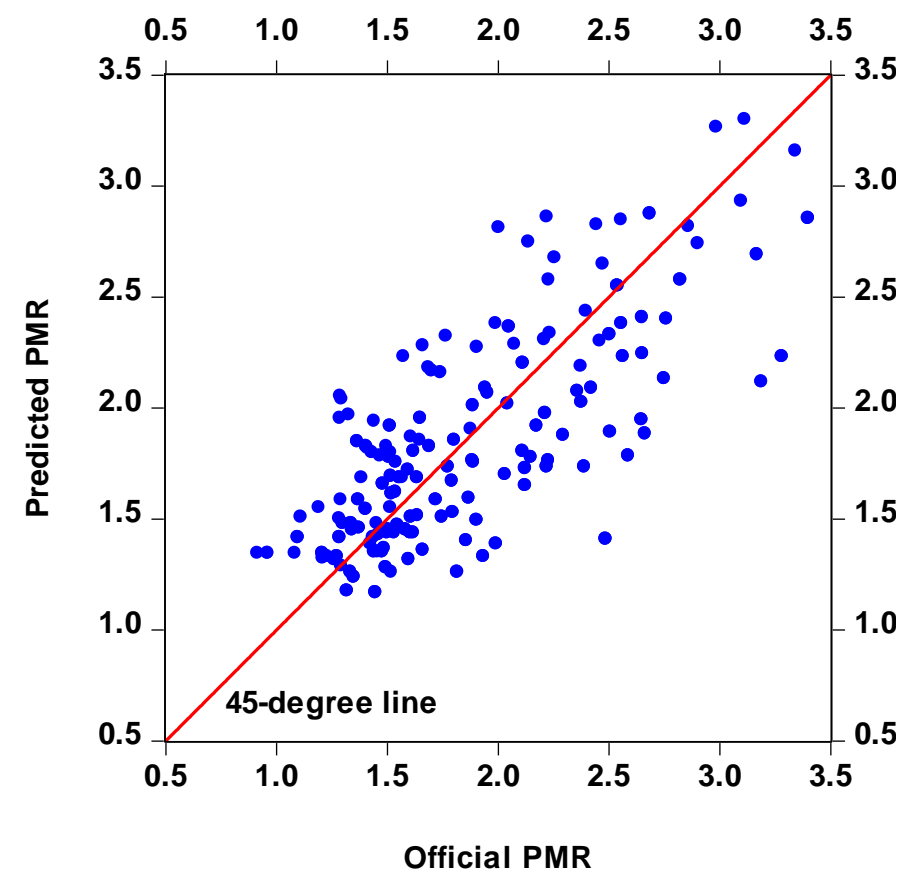

\section{Additional backcasting}

4. The operations described above yield interpolated and proxy PMR estimates back to, at best, 1996. All PMR measures are then backcasted to the beginning of the estimation period (1966) by keeping them constant at their earliest value (usually 1996). Official PMR and proxy PMR indices for 2008 are compared for all countries included in the main text's regressions in Figure A4.2. 


\section{Figure A4.2 Product market regulation}

Average index for the last period used in estimation (2006-10). Includes official and proxy measures. A higher value means more stringent regulation
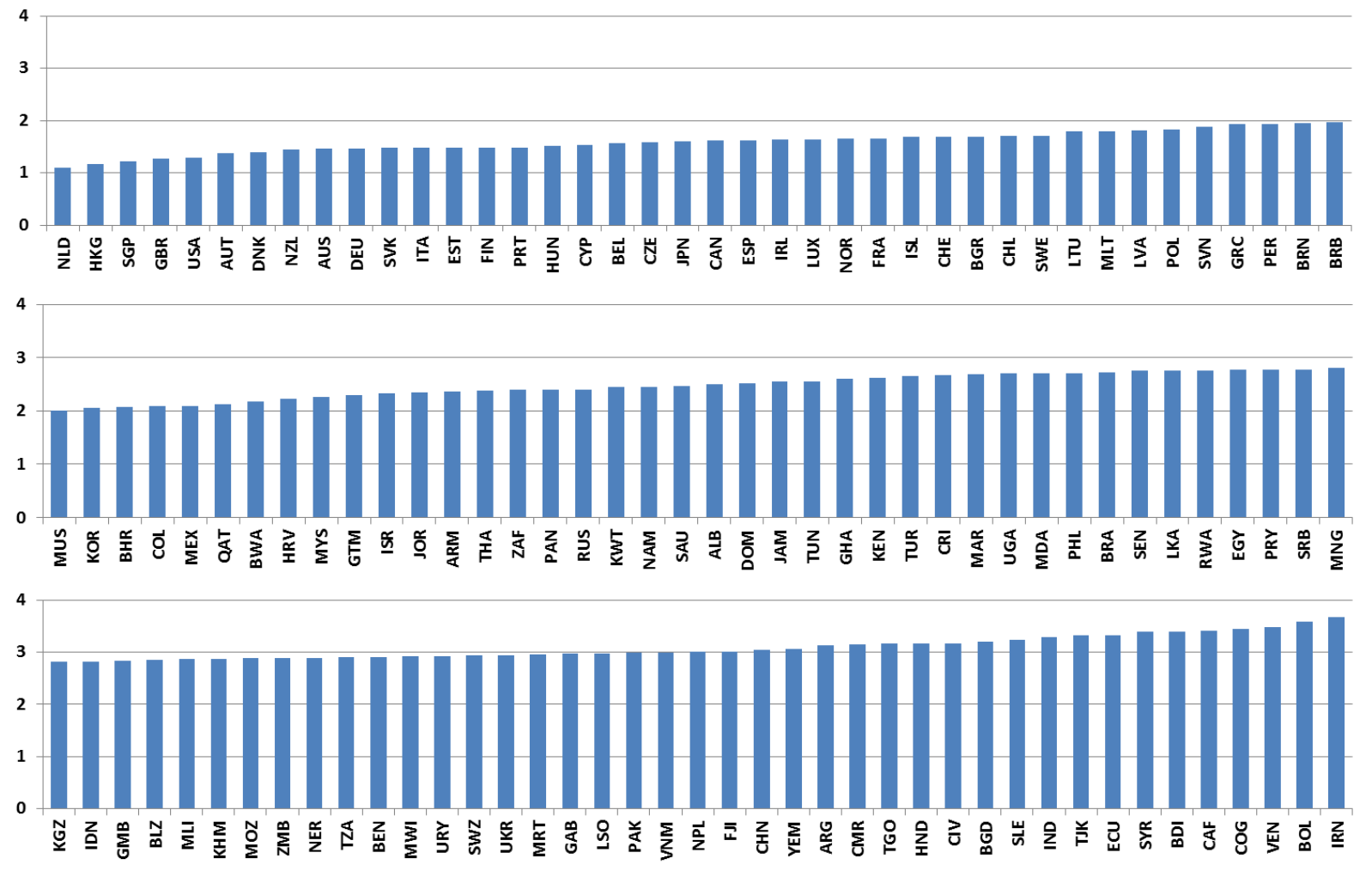

1. The information in the documents with reference to "Cyprus" relates to the southern part of the Island. There is no single authority representing both Turkish and Greek Cypriot people on the Island. Turkey recognizes the Turkish Republic of Northern Cyprus (TRNC). Until a lasting and equitable solution is found within the context of the United Nations, Turkey shall preserve its position concerning the "Cyprus issue".

2. The Republic of Cyprus is recognised by all members of the United Nations with the exception of Turkey. The information in the documents relates to the area under the effective control of the Government of the Republic of Cyprus.

Source: OECD Product Market Regulation database; Koske et al. (2015). 


\section{APPENDIX 5. CONSTRUCTING A HUMAN CAPITAL MEASURE}

1. The human capital index is constructed following a two-step procedure. First, data on average years of schooling in the working-age population are sourced from the international dataset of educational attainment of Barro and Lee (2013). Second, educational attainment measured in years of schooling is converted into a human capital measure by applying the transformation of Morrison and Murtin (2010), which features decreasing marginal returns to education. More specifically, the human capital index is given by:

$$
H_{i, t}=e^{0.1254 * A Y S_{i, t}-0.002 * A Y S_{i, t}^{2}}
$$

where $A Y S_{i, t}$ denotes average years of schooling in country $i$ and year $t$. On this measure, the United States ranks first among the OECD and BRIICS countries, while Turkey and Portugal rank lowest in the OECD area (Figure A5.1). South Africa ranks first among the BRIICS.

Figure A5.1 Measure of human capital based on educational attainment

Average index for the last period used in estimation (2006-10), higher is better
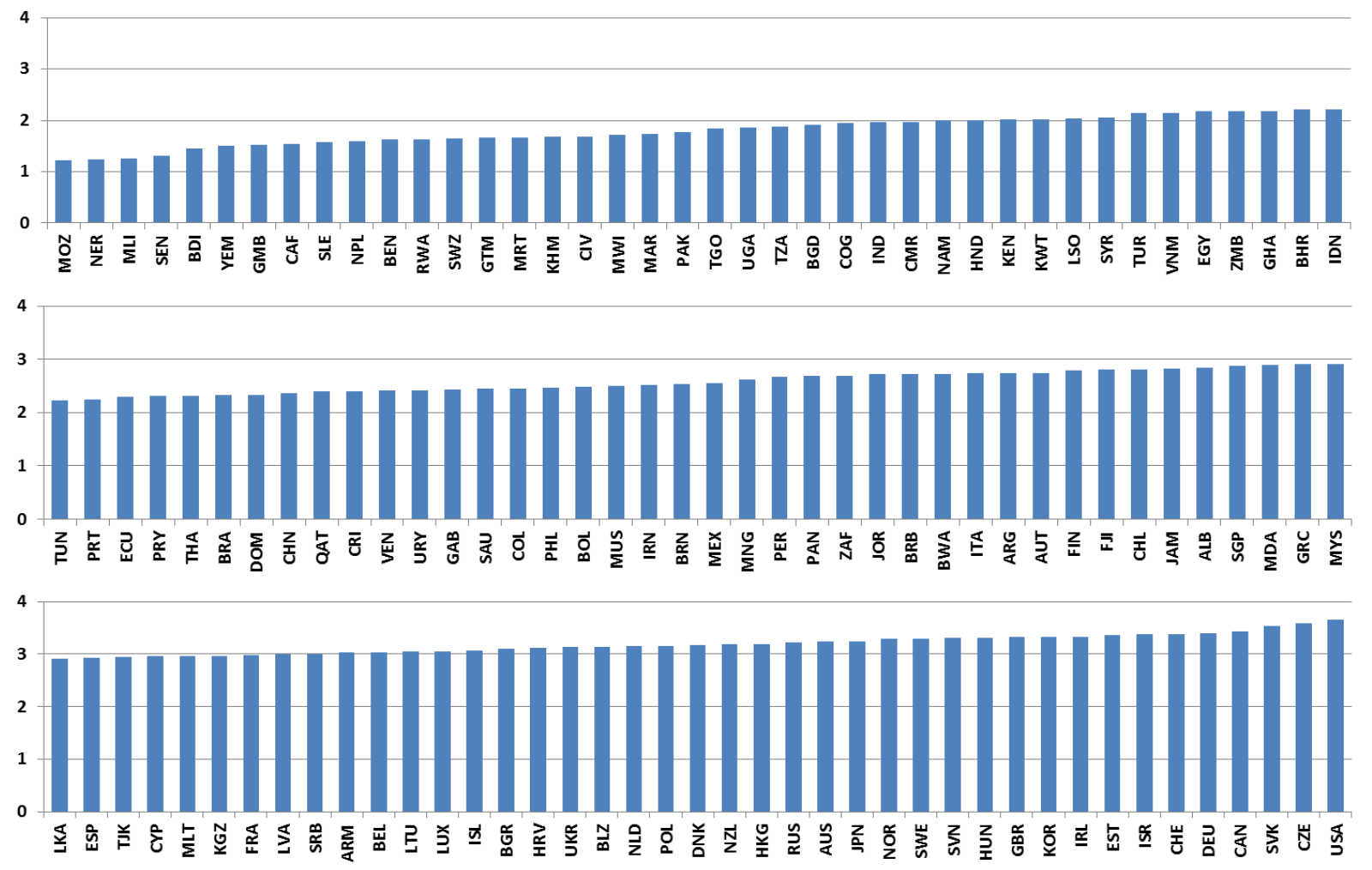

1. The information in the documents with reference to "Cyprus" relates to the southern part of the Island. There is no single authority representing both Turkish and Greek Cypriot people on the Island. Turkey recognizes the Turkish Republic of Northern Cyprus (TRNC). Until a lasting and equitable solution is found within the context of the United Nations, Turkey shall preserve its position concerning the "Cyprus issue".

2. The Republic of Cyprus is recognised by all members of the United Nations with the exception of Turkey. The information in the documents relates to the area under the effective control of the Government of the Republic of Cyprus.

Source: Barro and Lee (2013) based on Morrison and Murtin (2010). 


\section{APPENDIX 6. ROBUSTNESS TESTS}

1. This appendix presents a number of tests of robustness around the preferred equation (column 2 of Table 3 in the main text). For easy reference it is reproduced in column 1 of Table A6.1. This equation does not include the inequality variable estimated in column $2 \mathrm{c}$ of Table 3 as including it cuts the sample size too much. It also does not include the R\&D variables whose effects are taken from an external study as discussed in the main text.

Table A6.1. Robustness of the preferred estimated equation

Dependent variable: Annual growth rate of labour efficiency at fixed PPPs averaged over five-year periods

\begin{tabular}{|c|c|c|c|c|c|c|c|}
\hline & $(1)$ & (2) & (3) & (4) & $(5)$ & (6) & $(7)$ \\
\hline & $\begin{array}{l}\text { Preferred } \\
\text { equation }\end{array}$ & OECD only & $\begin{array}{c}\text { Non-OECD } \\
\text { only }\end{array}$ & $\begin{array}{c}\text { Variable } \\
\text { factor shares }\end{array}$ & GMM & \multicolumn{2}{|c|}{ With country fixed effects } \\
\hline log(Lagged labour efficiency) & $\begin{array}{l}-0.024^{\star * *} \\
(0.0022)\end{array}$ & $\begin{array}{l}-0.032^{* \star *} \\
(0.0055)\end{array}$ & $\begin{array}{l}-0.021^{* * *} \\
(0.0024)\end{array}$ & $\begin{array}{l}-0.032^{* * *} \\
(0.0084)\end{array}$ & $\begin{array}{l}-0.020^{* *} \\
(0.0083)\end{array}$ & $\begin{array}{l}-0.079^{* \star *} \\
(0.0069)\end{array}$ & $\begin{array}{l}-0.079^{* * *} \\
(0.0069)\end{array}$ \\
\hline Rule of law & $\begin{array}{l}0.090 * * * \\
(0.0156)\end{array}$ & $\begin{array}{l}-0.100^{*} \\
(0.0579)\end{array}$ & $\begin{array}{l}0.080^{* * *} \\
(0.0190)\end{array}$ & $\begin{array}{c}0.023 \\
(0.0403)\end{array}$ & $\begin{array}{l}0.102^{\star \star \star} \\
(0.0383)\end{array}$ & $\begin{array}{c}-0.002 \\
(0.0615)\end{array}$ & \\
\hline Population-adjusted openness & $\begin{array}{c}0.080^{* *} \\
(0.0387)\end{array}$ & $\begin{array}{c}0.123 \\
(0.1148)\end{array}$ & $\begin{array}{c}0.070 * \\
(0.0412)\end{array}$ & $\begin{array}{l}0.265^{\star * *} \\
(0.0847)\end{array}$ & $\begin{array}{c}0.178 \\
(0.1326)\end{array}$ & $\begin{array}{c}0.125 \\
(0.0775)\end{array}$ & $\begin{array}{c}0.122^{*} \\
(0.0669)\end{array}$ \\
\hline Human capital & $\begin{array}{l}0.017^{* * *} \\
(0.0042)\end{array}$ & $\begin{array}{c}0.002 \\
(0.0034)\end{array}$ & $\begin{array}{l}0.024^{* * *} \\
(0.0061)\end{array}$ & $\begin{array}{l}0.028^{* * *} \\
(0.0101)\end{array}$ & $\begin{array}{c}0.008 \\
(0.0070)\end{array}$ & $\begin{array}{c}0.011 \\
(0.011)\end{array}$ & $\begin{array}{c}0.011 \\
(0.011)\end{array}$ \\
\hline Low and stable inflation & $\begin{array}{l}0.002^{* * *} \\
(0.0007)\end{array}$ & $\begin{array}{l}0.003^{* * *} \\
(0.0009)\end{array}$ & $\begin{array}{l}0.003^{* * *} \\
(0.0007)\end{array}$ & $\begin{array}{c}0.002 \\
(0.0016)\end{array}$ & $\begin{array}{c}0.001 \\
(0.0012)\end{array}$ & $\begin{array}{l}0.004^{* * *} \\
(0.0008)\end{array}$ & $\begin{array}{l}0.004^{* * *} \\
(0.0007)\end{array}$ \\
\hline Product market regulation & $\begin{array}{l}-0.006^{* *} \\
(0.0027)\end{array}$ & $\begin{array}{c}0.006 \\
(0.0054) \\
\end{array}$ & $\begin{array}{c}-0.007^{*} \\
(0.0038)\end{array}$ & $\begin{array}{c}-0.008 \\
(0.0106) \\
\end{array}$ & $\begin{array}{c}-0.004 \\
(0.0040) \\
\end{array}$ & $\begin{array}{c}-0.002 \\
(0.0118) \\
\end{array}$ & $\begin{array}{c}-0.004 \\
(0.0096) \\
\end{array}$ \\
\hline $\begin{array}{l}\text { Rule of law * } \\
\text { log(Lagged labour efficiency) }\end{array}$ & $\begin{array}{l}-0.009^{* \star *} \\
(0.0016)\end{array}$ & $\begin{array}{c}0.010^{*} \\
(0.0056)\end{array}$ & $\begin{array}{l}-0.008^{* * *} \\
(0.0020)\end{array}$ & $\begin{array}{c}-0.001 \\
(0.0042)\end{array}$ & $\begin{array}{l}-0.010^{* *} \\
(0.0039)\end{array}$ & $\begin{array}{c}0.000 \\
(0.0063)\end{array}$ & \\
\hline $\begin{array}{l}\text { Population-adjusted openness * } \\
\text { log(Lagged labour efficiency) }\end{array}$ & $\begin{array}{l}-0.007^{*} \\
(0.0037) \\
\end{array}$ & $\begin{array}{l}-0.010 \\
(0.0111)\end{array}$ & $\begin{array}{c}-0.006 \\
(0.0040)\end{array}$ & $\begin{array}{l}-0.026^{* * *} \\
(0.0086)\end{array}$ & $\begin{array}{c}-0.017 \\
(0.0129) \\
\end{array}$ & $\begin{array}{c}-0.010 \\
(0.0075)\end{array}$ & $\begin{array}{c}-0.009 \\
(0.0064) \\
\end{array}$ \\
\hline Longest time period & $1966-2010$ & $1966-2010$ & $1966-2010$ & $1966-2010$ & $1971-2010$ & $1966-2010$ & $1966-2010$ \\
\hline Adjusted R-squared & 0.298 & 0.394 & 0.332 & 0.245 & 0.149 & 0.479 & 0.481 \\
\hline Fixed country effects & No & No & No & No & No & Yes & Yes \\
\hline Observations & 722 & 261 & 461 & 652 & 600 & 722 & 722 \\
\hline Countries & 121 & 35 & 86 & 104 & 118 & 121 & 121 \\
\hline
\end{tabular}

Note: Asterisks $\left({ }^{*},{ }^{* *},{ }^{* *}\right)$ indicate the statistical significance level $(10 \%, 5 \%, 1 \%)$ of the coefficients. Figures in parentheses are standard errors (White) robust to arbitrary heteroskedasticity and within-country serial correlation. All equations are estimated over non-overlapping five-year periods and all variables are period averages (NAs are not propagated) except for the (lagged) level of labour efficiency which is the end-of-period value. The dependent variable is expressed in USD at fixed 2010 Purchasing Power Parity. All equations include time fixed effects and all equations except (6) and (7) include dummy variables for Norway and Russia. See the text for an explanation of the different equations and Table A2.1 in Appendix 2 for data sources.

2. Columns 2 and 3 show the results of performing separate regressions on OECD (column 2) and non-OECD (column 3) countries. They show that the estimated speed of convergence in the preferred equation is a weighted average of slower convergence in non-OECD countries and faster convergence among OECD countries. Low and stable inflation and openness both have roughly similar long-run effects whether using the OECD or non-OECD samples. Other variables have little explanatory power on the OECD-only sample, however, whereas their coefficients on the non-OECD sample are close to those obtained on the full sample. This is not surprising considering that non-OECD countries make up most of the overall sample. Also, OECD countries presumably exhibit too little cross-country and time variation on slow-changing measures such as rule of law and human capital to identify precise effects. Including both $\mathrm{OECD}$ and non-OECD countries in the same regression boosts the between-country variation that can be exploited for identification. 
3. Column 4 shows the results of altering the dependent variable by using variable factor shares in the labour efficiency decomposition as opposed to the fixed factor shares (see section 2.1 in the main text). Data on factor shares are from the Penn World Tables v8.1, but they are not available for all countries in the original sample, hence the smaller sample size relative to the preferred equation. ${ }^{18}$ Besides the conceptual change in the labour efficiency measure, some of the differences in results thus come from the change in country coverage. Taking into account the somewhat higher convergence speed, the long-run effect of rule of law is smaller whereas those of human capital and particularly openness are larger than in the preferred model. Other effects are robust to the change in labour efficiency measurement.

4. Column 5 of Table A6.1 and Table A6.2 test the sensitivity of the estimates in the preferred equation to using different estimators.

- Column 5 of Table A6.1 uses the Generalized Method of Moments (GMM) estimator, with two lags of the independent variables as instruments. Apart from a larger openness effect and a smaller human capital effect, other effects appear quite robust to using this different estimator. Again, some of the variation in coefficients is due to the sample size being reduced relative to the preferred equation given the use of lagged values of the regressors as instruments.

- Table A6.2 reports results of the Dynamic Ordinary Least Squares (DOLS) estimator, which are obtained in two stages using annual data (hence the much larger number of observations as compared to Table A6.1). Stage one estimates long-term effects directly: it is essentially the preferred equation with the dependent variable in levels, but with one lead, one lag and the contemporaneous first difference of all regressors added to the specification (coefficient estimates for regressors in first differences are not reported in the table). Because results from this different specification are not directly comparable to those in Table A6.1, Figure A6.1 expresses them along with those of the preferred equation on a comparable basis. The rule of law and especially the PMR effects are similar. Other effects are weaker in the DOLS specification. Stage two estimates speed of convergence effects by regressing the first difference of the dependent variable on the lagged residuals of the long-term equation from stage one, along with interaction effects. The speed of convergence is similar to that estimated in the preferred equation. The rule of law effect on the speed of convergence is not statistically significant but the openness effect is and with a much larger magnitude than in the preferred equation.

\section{Doing away with country fixed effects}

5. The advantage of including country fixed effects in a regression model is that they perfectly pick up all country-specific time-invariant factors. This results in higher overall explanatory power, as exemplified by the higher adjusted $R^{2}$ of the fixed-effect models (columns 6 and 7 of Table A6.1). One disadvantage, however, is that the inclusion of fixed country effects biases the convergence speed upward. This is the Hurwitz bias found by Barro (2015) and mentioned in Appendix 1. Another disadvantage is that the estimated fixed effects say nothing about which important factors they pick up. The higher explanatory power is, in this sense, illusory: the fixed effects are like black boxes. Moreover, the fixed effects not only capture fixed country characteristics, such as geography, but also slow-moving characteristics, such as the quality of a country's institutions. For instance, it is intuitively obvious that better application of the rule of law should influence a country's growth prospects, yet the variable retains no explanatory power when fixed effects are included (column 6), and indeed dropping this variable affects other coefficients very little (column 7).

18. Furthermore, even when available, factor shares in this dataset are constant over certain periods in some countries, most often the beginning and end of the sample. This suggests that they were extended backward and forward at constant values. 
Table A6.2. Dynamic Ordinary Least Squares estimates

Dependent variables: Labour efficiency level (first stage) or growth rate (second stage) at fixed PPPs

\begin{tabular}{|c|c|c|}
\hline & $(1)$ & $(2)$ \\
\hline & $\begin{array}{l}\text { DOLS first } \\
\text { stage }\end{array}$ & $\begin{array}{l}\text { DOLS second } \\
\text { stage }\end{array}$ \\
\hline \multicolumn{3}{|l|}{ Long-term effects } \\
\hline Rule of law & $\begin{array}{l}0.357^{\star * *} \\
(0.1008)\end{array}$ & \\
\hline Population-adjusted openness & $\begin{array}{c}0.145 \\
(0.0927)\end{array}$ & \\
\hline Human capital & $\begin{array}{l}0.451^{* * *} \\
(0.1175)\end{array}$ & \\
\hline Low and stable inflation & $\begin{array}{c}0.016 \\
(0.0201)\end{array}$ & \\
\hline Product market regulation & $\begin{array}{c}-0.256 \\
(0.2024)\end{array}$ & \\
\hline \multicolumn{3}{|l|}{ Speed of convergence effects } \\
\hline Lagged residual from first stage & & $\begin{array}{l}-0.020^{* * *} \\
(0.0031)\end{array}$ \\
\hline Interaction with rule of law & & $\begin{array}{l}-0.0032 \\
(0.0032)\end{array}$ \\
\hline $\begin{array}{l}\text { Interaction with population- } \\
\text { adjusted openness }\end{array}$ & & $\begin{array}{l}-0.027^{\star \star \star} \\
(0.0066)\end{array}$ \\
\hline Longest time period & $1966-2010$ & $1966-2010$ \\
\hline Adjusted R-squared & 0.537 & 0.092 \\
\hline Fixed country effects & No & No \\
\hline Observations & 3621 & 3611 \\
\hline Countries & 120 & 120 \\
\hline
\end{tabular}

Notes: Asterisks $\left({ }^{*},{ }^{* *},{ }^{* * *}\right)$ indicate the statistical significance level $(10 \%, 5 \%, 1 \%)$ of the coefficients. Figures in parentheses are (White) standard errors robust to arbitrary heteroskedasticity and within-country serial correlation. The equations are estimated using annual data. The dependent variable is expressed in USD at fixed 2010 Purchasing Power Parity. The first-stage regression includes dummy variables for Norway and Russia as well as one lead, one lag and the contemporaneous first difference of all other regressors but coefficient estimates for these terms are not reported. The second-stage regression includes time fixed effects. See Table A2.1 in Appendix 2 for data sources.

\section{Figure A6.1. Comparison of Dynamic Ordinary Least Squares estimates with preferred equation}

Percent increase in long-run level of labour efficiency after one standard deviation change in productivity determinant

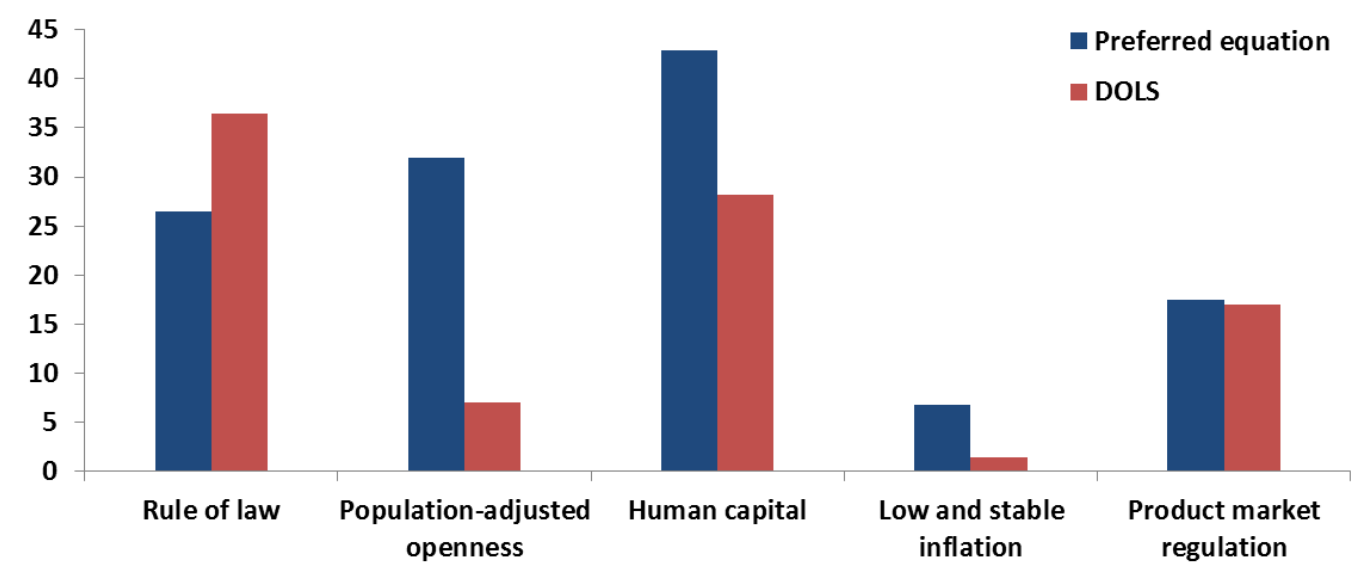


6. The scatter plots in Figure A6.2 are an attempt to peer into the black boxes of the fixed effects extracted from the model in column 8 . These are seen to be most closely correlated to indicators of institutional quality, and less so to variables measuring fixed country characteristics that are potentially important for growth convergence, such as geographical remoteness and average temperature. The correlation coefficients between the fixed effects and each of 'rule of law' and 'legal system and property rights' are around 0.65 , whereas it is around 0.5 for civil liberties and lower than 0.5 for other variables. These results are consistent with more careful studies which find no link between geographical factors and economic development, but a large role for institutions (Acemoglu et al., 2002; Acemoglu and Robinson, 2012).

7. In view of the trade-off between higher overall explanatory power and explicit estimates of the effect of institutions, and in view of ECO experience with the previous productivity convergence equation employing fixed country effects (see Appendix 1), this study proposes not to use them in the revised equation. This means, however, that the rule-of-law coefficient may partially capture the effect of other fixed or slow-moving country characteristics, institutions in particular. Therefore, the estimated rule-of-law effect is better interpreted as a general indicator of institutional quality than a narrow indicator of one aspect of the legal environment (see Appendix 7 for more on the rule of law). 


\section{Figure A6.2. Relationship between estimated fixed effects and time-invariant or slow-moving factors}

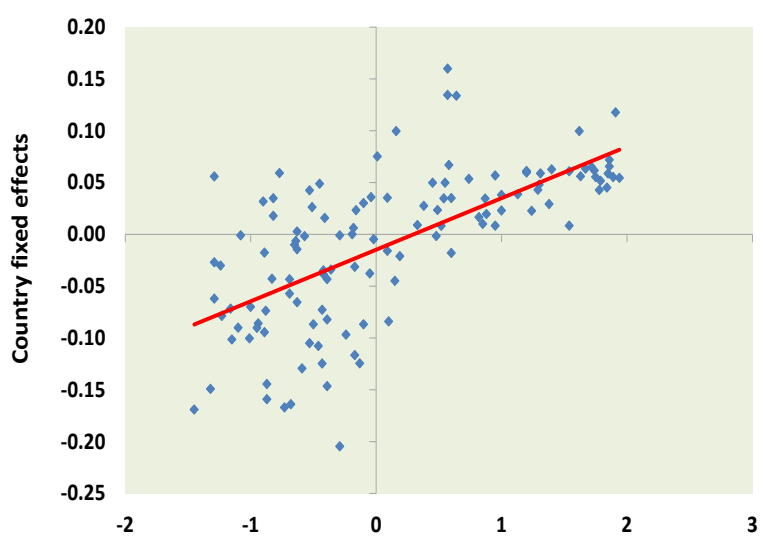

1. Rule of law

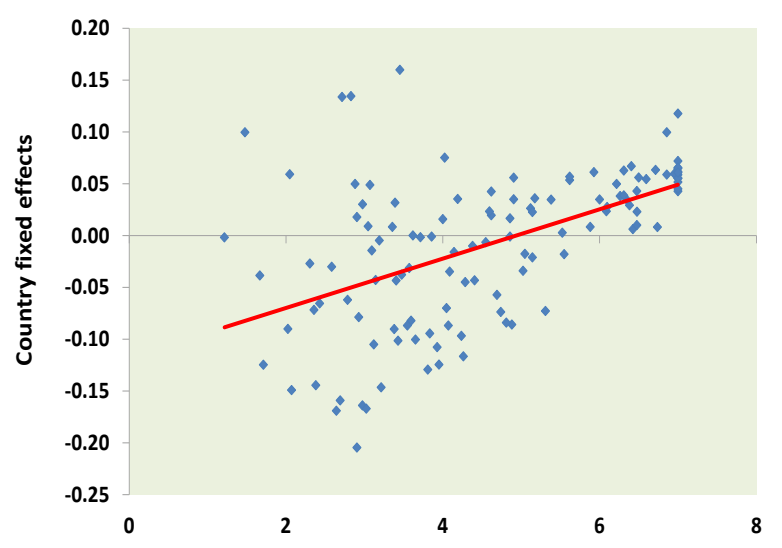

3. Civil liberties

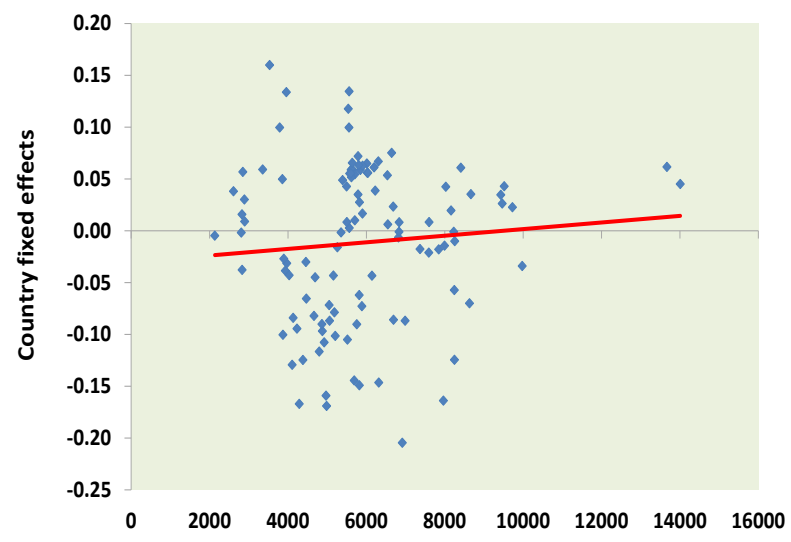

5. Geographical remoteness

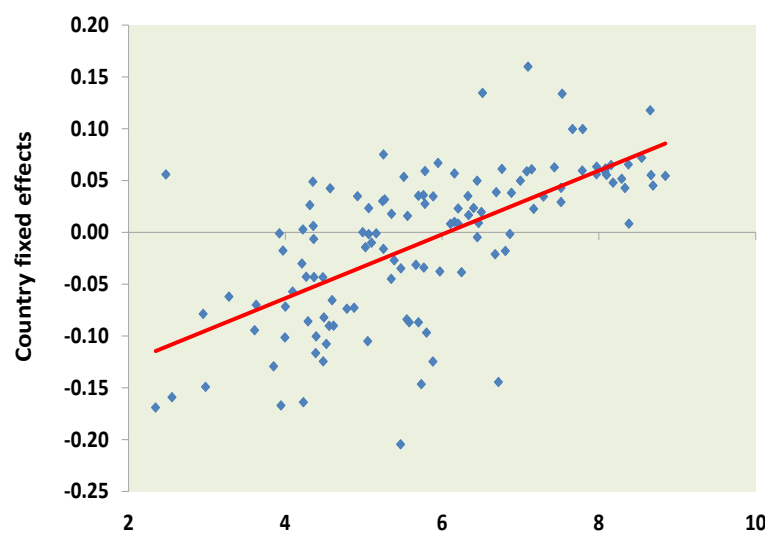

2. Legal system and property rights

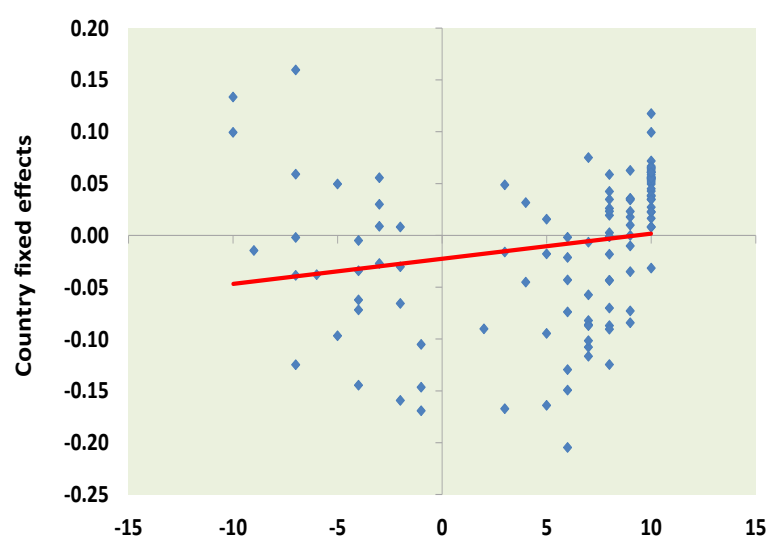

4. Combined polity score

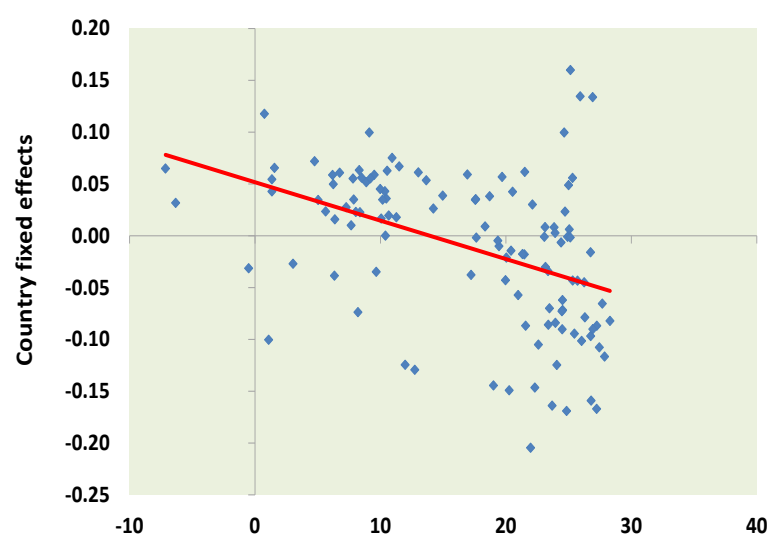

6. Average annual temperature

Sources and notes: The country fixed effects on the $y$-axes are extracted from the equation in column 8 of Table A6.1. 'Rule of law' is from the World Bank governance indicators. 'Legal system and property rights' is from the Fraser Institute's Economic Freedom of the World indices. 'Civil liberties' is from Freedom House. 'Combined polity score' is from the Center for Systemic Peace. 'Geographical remoteness' is from the United Nations Development Policy and Analysis Division. 'Average annual temperature' is from the World Bank Climate Change Knowledge Portal. When $x$-axis variables are time series, data were averaged over the 1966-2010 period to correspond to the fixed effects. 


\section{APPENDIX 7. INTERPRETING THE 'RULE OF LAW’ INDICATOR}

\section{Introduction and summary}

1. This appendix describes the perceptions-based rule of law variable used in the productivity convergence estimations and then goes on to consider the relative merits of alternative rules-based measures, including their usefulness in policy simulations. The main conclusion is that, while more objective rules-based measures can provide a useful focus for discussing the relative strengths and weaknesses of policy settings in a particular country, perceptions-based measures provide a more reliable overall summary measure of the rule of law, especially when the sample of countries considered includes both advanced and developing countries.

\section{The World Bank perceptions-based measure}

2. The rule of law variable is one of six governance indicators regularly updated by the World Bank, covering over 200 countries since 1996 (Kaufmann, Kraay and Mastruzzi, 2010). It is intended to capture "perceptions of the extent to which agents have confidence in and abide by the rule of society, and in particular the quality of contract enforcement, property rights, the police, and the courts, as well as the likelihood of crime and violence". In its own empirical work to explain differences in GDP per capita, the World Bank has tended to use the rule of law, rather than other governance indicators, because it relates most closely to issues of contract enforcement and property rights, which are considered most critical in the growth literature (Kaufmann and Kray, 2002). ${ }^{19}$

3. The other World Bank governance indicators relate to: Voice and Accountability; Political Stability and Absence of Violence/Terrorism; Government Effectiveness; Regulatory Quality; and Control of Corruption. The different governance indicators are highly correlated, for instance the correlation coefficient between the rule of law and the other governance indicators vary from 0.77 to 0.97 (Table A7.1). This precludes using more than one indicator in the same estimation. It also suggests that, both individually and collectively, the governance indicators capture more than their nomenclature suggests: they reflect the overall quality of a country's democratic, legal and governmental institutions.

4. All these indicators rely exclusively on perceptions-based data sources, which include surveys of firms, households, commercial business information providers, non-governmental organisations and a number of multilateral organisations and other public bodies. The different data sources (up to 15 in the case of the rule of law) are combined into a single indicator using an unobserved components model (for details see Kaufmann, Kraay and Mastruzzi, 2010) as a weighted average of re-scaled survey scores for each country, assuming a normal distribution for the final indicator. This methodology allows confidence intervals to be generated around the final indicators for each country and the World Bank authors advise that when the confidence intervals of two countries overlap, then the estimated difference in governance is too small to be statistically significant (a point which is emphasised further below).

19. Other survey-based measures of the rule of law are available, but typically their time and country coverage is more limited, and in any case they are typically highly correlated with the World Bank measure. For example, the Economic Survey of Turkey (OECD, 2016) recently made use of the rule of law measure from the World Justice Project, which is also survey-based. The cross-country correlation coefficient with the World Bank measure for the most recent year was 0.94 
Table A7.1. Correlation coefficients between various indicators of institutional quality

\begin{tabular}{|c|c|c|c|c|c|c|c|c|c|c|}
\hline & $\begin{array}{c}\text { Voice and } \\
\text { accountability }\end{array}$ & $\begin{array}{c}\text { Political } \\
\text { stability and } \\
\text { absence of } \\
\text { violence } \\
\end{array}$ & $\begin{array}{l}\text { Government } \\
\text { effectiveness }\end{array}$ & $\begin{array}{l}\text { Regulatory } \\
\text { quality }\end{array}$ & $\begin{array}{l}\text { Rule of } \\
\text { law }\end{array}$ & $\begin{array}{l}\text { Control of } \\
\text { corruption }\end{array}$ & $\begin{array}{l}\text { Legal } \\
\text { system and } \\
\text { property } \\
\text { rights }\end{array}$ & $\begin{array}{l}\text { Political } \\
\text { rights }\end{array}$ & $\begin{array}{c}\text { Civil } \\
\text { liberties }\end{array}$ & $\begin{array}{c}\text { Combined } \\
\text { polity } \\
\text { score }\end{array}$ \\
\hline Voice and accountability $^{1}$ & 1.00 & & & & & & & & & \\
\hline Political stability and absence of violence ${ }^{1}$ & 0.67 & 1.00 & & & & & & & & \\
\hline Government effectiveness ${ }^{1}$ & 0.77 & 0.72 & 1.00 & & & & & & & \\
\hline Regulatory quality ${ }^{1}$ & 0.79 & 0.72 & 0.94 & 1.00 & & & & & & \\
\hline Rule of law 1 & 0.78 & 0.77 & 0.97 & 0.94 & 1.00 & & & & & \\
\hline Control of corruption ${ }^{1}$ & 0.76 & 0.77 & 0.94 & 0.89 & 0.96 & 1.00 & & & & \\
\hline Legal system and property rights ${ }^{2}$ & 0.60 & 0.75 & 0.90 & 0.85 & 0.92 & 0.89 & 1.00 & & & \\
\hline Political rights ${ }^{3}$ & 0.94 & 0.54 & 0.62 & 0.65 & 0.62 & 0.58 & 0.43 & 1.00 & & \\
\hline Civil liberties $^{3}$ & 0.96 & 0.66 & 0.70 & 0.73 & 0.71 & 0.68 & 0.53 & 0.95 & 1.00 & \\
\hline Combined polity score ${ }^{4}$ & 0.84 & 0.35 & 0.45 & 0.54 & 0.43 & 0.40 & 0.21 & 0.89 & 0.85 & 1.00 \\
\hline
\end{tabular}

Sources and notes: 1. From the World Bank governance indicators. 2. From the Fraser Institute's Economic Freedom of the World indices. 3. From Freedom House. 4. From the Center for Systemic Peace. For all variables, a higher score is better. Correlation coefficients are computed using the largest possible number of countries within the set of 121 countries that compose the sample of the preferred equation. The data are for 2010 or thereabout.

\section{Alternative rules-based indicators of governance}

5. The alternative to a survey-based measure of governance is a rules-based measure. There are several examples of rules-based indicators of governance, including: the Doing Business dataset of the World Bank, which provides detailed information on the legal and regulatory environment of a large set of countries; the Polity-IV database, which reports detailed factual information on the features of political systems; and the Global Integrity index, which provides detailed information on the legal framework governing public sector accountability and transparency.

6. The attraction of such indicators is their clarity. For example, it is relatively easy to measure whether or not a country has a legally independent anticorruption commission, or the time and costs typically involved in resolving a contract dispute or insolvency. This in turn means that it is possible to make specific policy recommendations and monitor progress. However, a drawback of such measures is that there can be major gaps between laws "on the books" and their implementation "on the ground", as proxied by perceptions-based measures. This may be especially true of developing countries where corruption may undermine the fair application of codified rules (Kaufmann and Kray, 2008). Examples of disconnects between de jure rules and their de facto implementation include:

- In all of the countries covered by the Global Integrity Index it is illegal to bribe a public official, and all but a very few have some form of anticorruption agency, but there is massive variation in perceptions-based measures of corruption among these same countries.

- The World Bank Doing Business dataset includes the average time to resolve a contract dispute which ranks the Russian Federation, Uzbekistan, South Sudan and Rwanda in the top decile of countries (in terms of having a fast resolution), all ahead of G7 countries. Even on a broader measure of contract enforcement, which weighs together a number of sub-components, including "the quality of the judicial process", the Russian Federation $\left(5^{\text {th }}\right)$ and China $\left(7^{\text {th }}\right)$ rank ahead of all G7 countries.

7. A separate issue relates to the interpretation of the rule of law variable as a broad measure capturing many aspects of the legal and political system (in line with the World Bank definition quoted above) or, even more broadly, the overall quality of institutions. Under this broad interpretation, even if it were possible to find a rules-based measure exhibiting plausible country rankings, which also worked well in estimation, it would be of dubious usefulness in policy simulations unless it also captured many aspects of the system. In the case of a narrow measure of specific aspects of the legal and political environment, a small estimated impact might be plausible, but of little interest in policy simulations, whereas a large 
estimated impact would almost surely be spurious and suggest that the measure was standing in for many other aspects of the institutional environment well correlated with it. Auxiliary regressions to 'explain' a broad perceptions-based index like rule of law using a set of rules-based measures would suffer from similar defects: even if some of them were able to 'predict' the rule of law measure with some accuracy, it would make little sense to attribute to narrow policy indicators the large impact on productivity associated with the rule of law. Moreover, linking productivity improvements to very specific codified aspects of the legal and political system would make it more difficult to relate model simulations to the typical Survey discussions which, when they have emphasised rule of law issues, have been much more wide ranging (see for example recent Surveys of Mexico, Italy and Turkey).

\section{Use of the rule of law variable in policy simulations}

8. While it is argued above that perceptions-based indicators of governance are likely to be more reliable than rules-based indicators as an overall summary measure, there is an issue that perceptions-based indicators are more difficult to link back to specific policy interventions that might influence outcomes. The following discussion provides some examples as to how the rule of law variable might be used in model-based simulations.

9. Firstly, it is worth repeating that the rule of law concept is subject to measurement error and the World Bank recognises this by providing confidence intervals around the measure for each country (such confidence intervals tend to be larger for countries when based on fewer sources). The confidence intervals for the majority of high-income OECD countries overlap, casting doubt on how meaningful it would be to try to emphasise differences between them or the implications they have for productivity.

10. On the other hand, there are a number of OECD countries - including Mexico, Turkey and Italy where the confidence interval for the rule of law is well outside of the range for the majority of other OECD countries and where issues relating to the rule of law, judicial independence and corruption have been identified as priorities for reform in recent Economic Surveys. In these cases, model simulations indicating the potential gains to productivity from reforms that could raise the rule of law measure to, say, the OECD median, would illustrate their potential importance quantitatively and provide useful background to a more detailed country-specific discussion of the reforms needed.

11. Another example of the potential usefulness of rule of law simulations is in modelling the potential for catch-up in the living standards of BRIICS countries, given that the rule of law measure in these countries remains well below that of most OECD countries. For example, in a baseline projection, the rule of law might be assumed to remain constant at recent historical values, whereas in a variant simulation it could gradually evolve to the OECD median. Given that it has a large estimated impact both on the steady-state level of productivity and on the speed of convergence to the steady state, such simulations could provide a powerful policy message regarding the importance of improving the quality of institutions. 